UNIVERSIDADE DE BRASÍLIA

INSTITUTO DE CIÊNCIAS BIOLÓGICAS

PROGRAMA DE PÓS-GRADUAÇÃO EM ECOLOGIA

MARCOS ANTÔNIO DA SILVA ELIAS

\title{
AMEAÇAS DA PERTURBAÇÃO ANTRÓPICA A ABELHAS NATIVAS POLINIZADORAS DO TOMATEIRO
}




\section{AMEAÇAS DA PERTURBAÇÃO ANTRÓPICA A ABELHAS NATIVAS POLINIZADORAS DO TOMATEIRO}

Tese apresentada ao Programa de Pós-

Graduação em Ecologia, Instituto de Ciências Biológicas da Universidade de Brasília, como requisito parcial para obtenção do título de Doutor em Ecologia.

Orientador: Prof. Dr. Edison Ryoiti Sujii

Co-orientadora: Profa. Dra. Edivani

Villaron Franceschinelli 
"No final, só preservaremos o que amarmos, e só amaremos o que compreendermos, e só compreenderemos o que nos for ensinado".

Baba Dioum 


\title{
DEDICATÓRIA
}

Em memória ao meu pai, Antonio Afonso da Silva,

à minha mãe Divina Elias

e ao meu filho Heitor Elias Ferreira

\author{
pelo amor, \\ pela esperança, \\ pelos momentos de alegria, \\ aprendizado \\ incessantemente... \\ Dedico
}




\section{AGRADECIMENTOS}

À Maria Rita de Cássia Campos e Regina H.F. Macedo que ao me iniciar nos caminhos da pesquisa possibilitaram que o caminho pudesse ser percorrido, pela amizade e exemplo.

Ao Amigo Delfino Costa Machado por me mostrar o que realmente é importante na vida.

Ao meu orientador professsor Dr. Edison Ryoiti Sujii pela orientação, apoio, compreensão e incentivo durante todos os momentos dessa trajetória.

À minha co-orientadora professsora Dr ${ }^{\mathrm{a}}$. Edivani Villaron Franceschinelli pela confiança, oportunidade e paciência.

Ao professor Dr. Pedro Vale de Azevedo Brito pelo aprendizado e parceria.

À professora $\operatorname{Dr}^{\mathrm{a}}$ Daniela de Melo e Silva e ao pessoal do laboratório de Laboratório de Genética e Biodiversidade pela oportunidade, disponibilidade e apoio em todas as etapas do trabalho sobre genotoxicidade.

Aos amigos de todas as horas, Fábio Júlio, Juliana, Flaviana, Grayce, Carlos, Zé, Pedro, Kathila, Macks e tantos outros que tornam minha lista infinita e meu coração feliz.

A todos os professores do curso de pós-graduação em Ecologia, pela disponibilidade em sanar dúvidas e direcionar a aquisição de conhecimentos, tão preciosos para a conclusão desta tese e para minha atuação profissional futura.

Aos membros da Banca Examinadora, pela disposição em analisar este trabalho.

Agradeço órgãos financiadores de parte desse projeto CNPq e FUNBIO. Que forneceram o incentivo necessário para a execução desse estudo. 
Aos órgãos de fomento que me concederam a bolsa de estudos e pesquisa. Sem a qual não seria possível realizar o trabalho.

A todas as pessoas que de alguma forma contribuíram em todas as etapas deste trabalho. 


\section{SUMÁRIO}

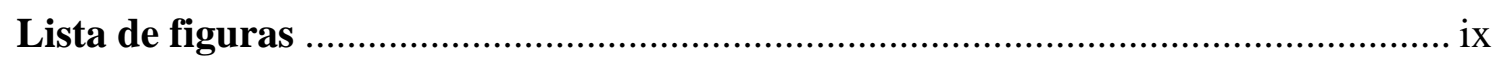

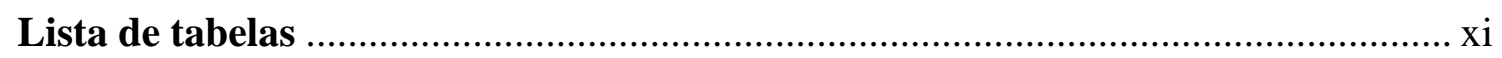

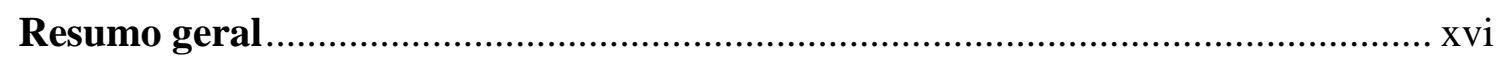

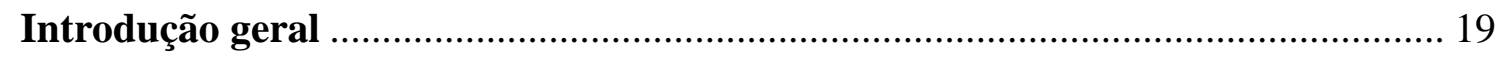

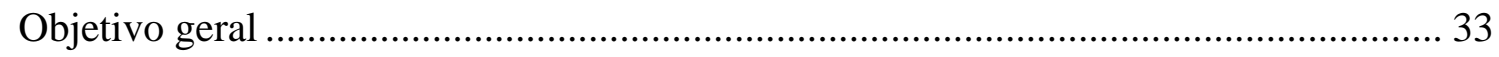

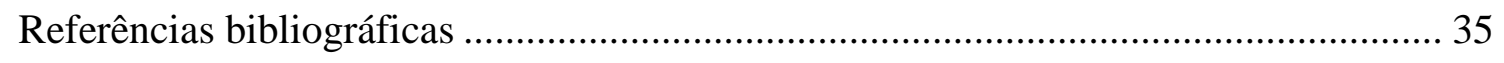

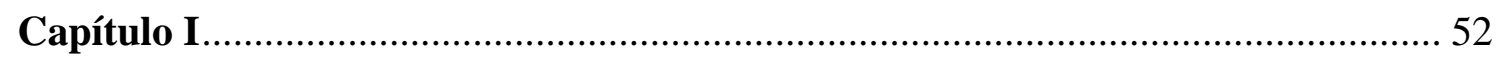

Influência do contexto da paisagem na abundância de abelhas nativas em cultivos de

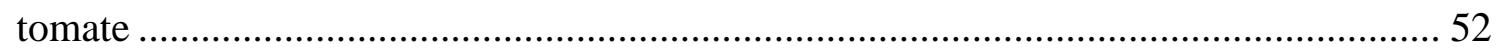

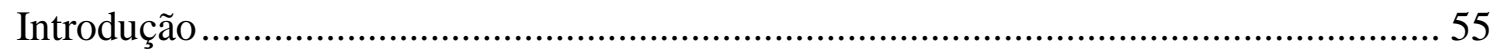

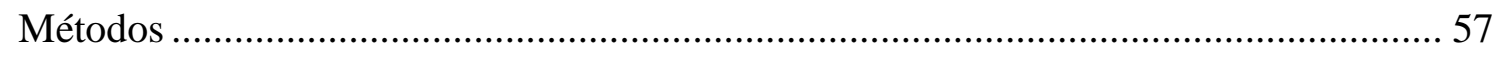

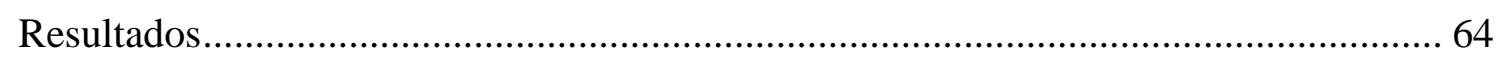

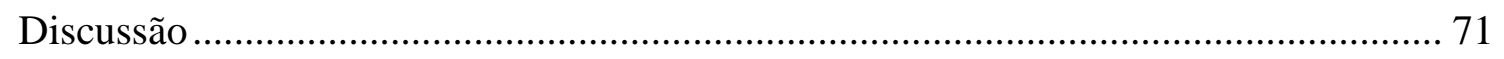

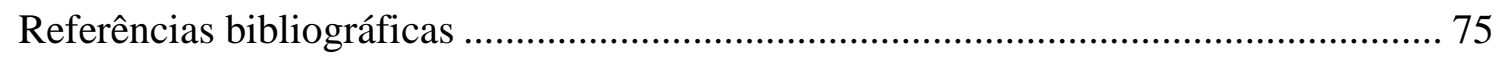

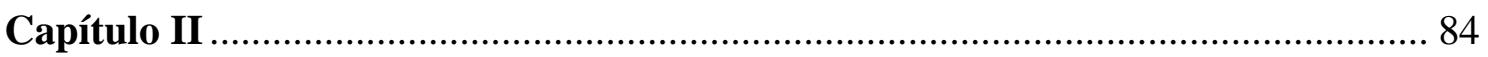

Avaliação de danos ao DNA em abelhas Melipona quadrisfaciata expostas in vivo a concentrações subletais dos inseticidas imidacloprid e deltametrina............................. 84

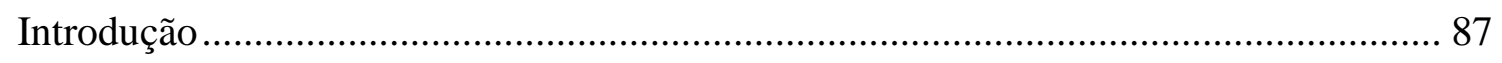

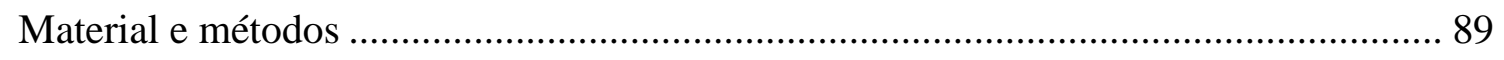

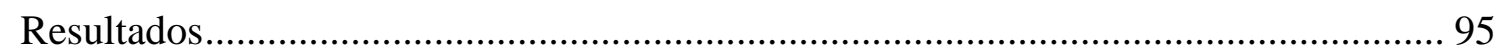

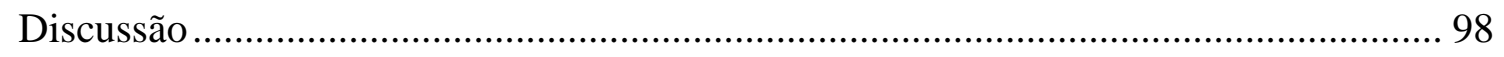

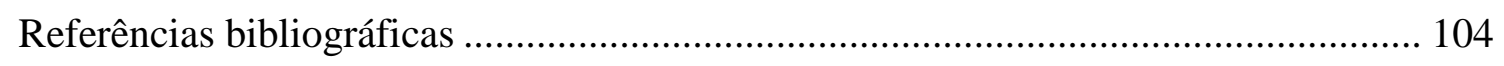

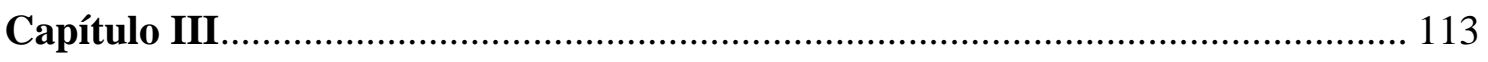


Climate change threatens pollination services in tomato crops in Brazil

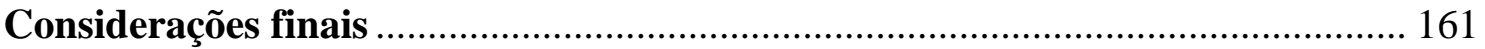

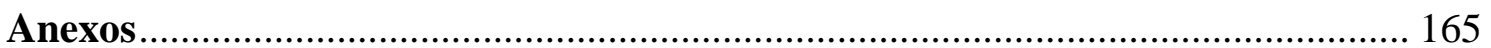




\section{Lista de figuras}

\section{Capítulo I}

Figura 1. Localização de 10 cultivos de tomate convencional estaqueado em campo aberto em 2010 e de 14 cultivos em 2011. Triângulos preenchidos correspondem ao ano de 2010 e círculos preenchidos correspondem ao ano de 2011. .58

Figura 2. Cultivo de tomate ao centro e os cinco círculos de 0,75,1,0, 1,5,2,0 e 3,0 km de raio delimitados para o cálculo da vegetação e do tamanho relativo do maior fragmento (RLPs) .59

Figura 3. Coeficiente padronizado do efeito de cada variável preditora sobre a abundância de abelhas dos modelos médios para cada grupo de abelhas polinizadoras do tomateiro em cultivos convencionais estaqueados em campo aberto no estado de Goiás.

( ) correspondem aos 10 cultivos onde foram coletados os dados de abundância no ano de 2010 e $(\bullet)$ correspondem aos 14 cultivos no ano de 2011. Linhas verticais indicam 1,96 vezes o desvio padrão. (Prop) Proporção de vegetação nativa, (rLPS) tamanho relativo do maior fragmento e (Obsv. time) tempo de observação. Variáveis preditoras selecionadas: Prop. $1 \mathrm{~km}, 1,5 \mathrm{~km}, 2 \mathrm{~km}, 3 \mathrm{~km}$ e rLPS $2 \mathrm{~km}$ e $3 \mathrm{~km}$. Standardized coefficient: coeficiente padronizado da abundância de abelhas. .70

\section{Capítulo II}

Figura 1. Efeitos de 72 horas de exposição aos inseticidas imidacloprid (I) e deltametrina (D) em duas concentrações subletais (\%) para cada inseticida sobre o DNA de hemócitos de abelhas operárias da espécie Melipona quadrifasciata. MCO corresponde ao momento da cauda de Olive; Controle (-) no eixo x corresponde ao controle negativo; D, corresponde ao inseticida deltametrina em duas concentrações 
subletais e I, corresponde ao inseticida imidacloprid também em duas concentrações subletais. Círculos preenchidos correspondem a média e linhas verticais indicam o desvio padrão. Letras iguais indicam que não há diferença estatisticamente significativa e letras diferentes indicam diferenças significativas, $\mathrm{P}<0,05$ .98

\section{Capítulo III}

Figure 1. Shifts in suitable habitat areas of five wild bee species (expressed as proportional reductions compared with the present scenarios) in an optimistic (green bars), and a pessimistic scenario (grey bars) of future climate change for the year 2100 . Vertical spreads represent the shifts computed using the $2.5 \%$ and the $97.5 \%$ quantiles of all suitability values obtained for each cell. A. callichroa (Augochloropsis callichroa), B. morio (Bombus morio), C. tarsata (Centris tarsata), Ex. analis (Exomalopsis analis) and Eu.nigrita (Eulaema nigrita). 138

Figure 2. Consensus maps for five species of native bees of the current, optimistic (RCP 2.6 - 2100) and pessimistic (RCP 2.6 - 2100) scenarios of future climate change for the year 2100. Five models were combined through an ensemble of forecasts to generate these consensus maps 


\section{Lista de tabelas}

\section{Capítulo I}

Tabela 1. Critérios para agrupamento de espécies de abelhas nativas observadas nos cultivos de tomate convencional estaqueado em campo aberto com base na similaridade morfo-ecológica.

Tabela 2. Valores médios, mínimo e máximo de proporção de vegetação nativa (Prop) e do tamanho relativo do maior fragmento (rLPS) para cinco círculos (buffers) de diferentes raios no entorno de 10 cultivos de tomate convencional estaqueado em campo aberto no estado de Goiás em 2010 e de 14 cultivos em 2011 .65

Tabela 3. Frequência relativa $(\%)$ de visitas dos diferentes grupos de abelhas às flores do tomateiro em 10 cultivos de tomate convencional estaqueado em campo aberto em 2010 e 14 cultivos em 2011 no estado de Goiás. N corresponde a número de indivíduos. .66

Tabela 4. Descritores dos modelos selecionados para a relação entre a abundância de abelhas nativas nas flores de tomateiros e a proporção de vegetação nativa (Prop) e o tamanho relativo do maior fragmento (rLPS) para os cinco grupos de espécies de abelhas em 10 cultivos de tomate convencional estaqueado em campo aberto no ano de 2010 e em 14 cultivos de tomate no ano de 2011 no estado de Goiás. Os valores de Delta são as diferenças entre o AICc de cada modelo e o AICc do melhor modelo. Pesos de Akaike (Weigth) são estimativas normalizadas da probabilidade relativa de cada modelo e são utilizados no cálculo do modelo médio de forma que os melhores modelos têm uma maior contribuição para a estimativa dos coeficientes médios. Valores de Pseudo $\mathrm{R}^{2}$ foram calculados utilizando a formulação de Heinzl \& Mittlbock (2003). Testes qui-quadrado da razão de verossimilhança (L.ratio $\chi^{2}$ ) foram usados para testar se a diferença entre o desvio do modelo ajustado e o desvio do modelo nulo são 
significativas. K, o número de parâmetros do modelo; Obsv. tempo, tempo de observação

Tabela 5. Relação entre a distância dos remanescentes de vegetação nativa mais próximos dos cultivos de tomateiro e a abundância de cinco grupos de abelhas nas flores do tomateiro em 10 cultivos convencionais estaqueados em campo aberto no ano de 2010 e nos 14 cultivos em 2011 no estado de Goiás. Os pequenos valores de variância nas inclinações do efeito aleatório do ano indicam que as respostas em ambos os anos foram similares .71

\section{Capítulo II}

Tabela 1. Divisão e descrição dos grupos experimentais de abelhas da espécie Melipona quadrifasciata expostas a solução de $50 \%$ de sacarose e a solução de $50 \%$ de sacarose acrescida de imidacloprid e deltametrina durante 72 horas

Tabela 2. Valores médios e desvio padrão do momento da cauda de Olive (MCO) em hemócitos de abelhas operárias da espécie Melipona quadrifasciata expostas a dois tipos de inseticidas em diferentes concentrações subletais. U.A.: unidade arbitrária .96

Tabela 3. Análise de variância testando o efeito entre os inseticidas imidacloprid e deltametrina, entre as concentrações subletais e entre os inseticidas e as concentrações (interação) sobre o momento da cauda de Olive (MCO) em hemócitos de abelhas operárias da espécie Melipona quadrifasciata. .97 


\section{Capítulo III}

Table 1. Agreement between tomatoes cropped areas in hectares and the presence of five bee species in these areas in the current, optimistic (RCP 2.6) and pessimistic (RCP 8.5) future scenarios. The values in parentheses represent the percentage the concordance between the area planted tomato in Brazil and occurs in suitable cells for each species. Ex. analis (Exomalopsis analis), B. morio (Bombus morio), Eu. nigrita (Eulaema nigrita), C. tarsata (Centris tarsata) and A. callichroa (Augochloropsis callichroa) 140

Table A1. Scores the area under the receiver operating characteristic (ROC) curve (AUC) and true skill statistic (TSS) to ensemble forecasting, random forest (RF), flexible discriminant analysis (FDA), Generalized linear models (GLM), classification tree analysis (CTA) and Maximum Entropy (MAXENT) and cutoff AUC and TSS to each specie. Ex. analis (Exomalopsis analis), B. morio (Bombus morio), Eu. nigrita (Eulaema nigrita), C. tarsata (Centris tarsata) and A. callichroa (Augochloropsis callichroa) 160

\section{Anexos}

\section{Anexo 1: Material suplementar do capítulo I}

Tabela S1. Estimativas dos coeficientes dos modelos médios para a relação entre a abundância de abelhas do grupo Buzzers nas flores dos cultivos de tomate e a proporção de vegetação nativa (Prop) e o tamanho relativo do maior fragmento (rLPS) em 10 cultivos de tomate convencional estaqueado em campo aberto no ano de 2010 e 14 cultivos de tomate no ano de 2011. IC-inferior, intervalo de confiança limite inferior e IC-superior, intervalo de confiança limite superior, Obsv. tempo, tempo de observação 166 
Tabela S2. Estimativas dos coeficientes dos modelos médios para a relação entre a abundância de abelhas do grupo Exomalopis nas flores dos cultivos de tomate e a proporção de vegetação nativa (Prop) e o tamanho relativo do maior fragmento (rLPS) em 10 cultivos de tomate convencional estaqueado em campo aberto no ano de 2010 e 14 cultivos de tomate no ano de 2011. IC-inferior, intervalo de confiança limite inferior e IC-superior, intervalo de confiança limite superior, Obsv. tempo, tempo de observação 167

Tabela S3. Estimativas dos coeficientes dos modelos médios para a relação entre a abundância de abelhas do grupo Halictidae nas flores dos cultivos de tomate e a proporção de vegetação nativa (Prop) e o tamanho relativo do maior fragmento (rLPS) em 10 cultivos de tomate convencional estaqueado em campo aberto no ano de 2010 e 14 cultivos de tomate no ano de 2011. IC-inferior, intervalo de confiança limite inferior e IC-superior, intervalo de confiança limite superior, Obsv. tempo, tempo de observação 168

Tabela S4. Estimativas dos coeficientes dos modelos médios para a relação entre a abundância de abelhas do grupo Centris nas flores dos cultivos de tomate e a proporção de vegetação nativa (Prop) e o tamanho relativo do maior fragmento (rLPS) em 10 cultivos de tomate convencional estaqueado em campo aberto no ano de 2010 e 14 cultivos de tomate no ano de 2011. IC-inferior, intervalo de confiança limite inferior e IC-superior, intervalo de confiança limite superior, Obsv. tempo, tempo de observação 169

Tabela S5. Estimativas dos coeficientes dos modelos médios para a relação entre a abundância de abelhas do grupo Bombus/Eulaema nas flores dos cultivos de tomate e a proporção de vegetação nativa (Prop) e o tamanho relativo do maior fragmento (rLPS) em 10 cultivos de tomate convencional estaqueado em campo aberto no ano de 2010 e 
14 cultivos de tomate no ano de 2011. IC-inferior, intervalo de confiança limite inferior e IC-superior, intervalo de confiança limite superior, Obsv. tempo, tempo de

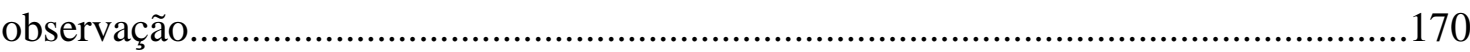

Tabela S6. Variáveis preditoras e variáveis respostas para os 24 cultivos de tomateiro convencional estaqueado em campo aberto em 2010 e 2011. (Prop.) corresponde a proporção de vegetação nativa, (rLPS) tamanho relativo do maior fragmento e (A. Buz.) abundância de todos polinizadores juntos (Buzzers), (A. Exo), abundância do grupo Exomalopsis, (A.Centris) abundância do grupo Centris, (A. Halic) abundância do grupo Halictidae e (A.B/Eu) abundância do grupo Bombus/Eulaema ....................................171 


\section{Resumo geral}

Há evidências do declínio da abundância de polinizadores e consequentemente dos seus serviços em algumas regiões do mundo, com possíveis impactos negativos para o funcionamento dos ecossistemas. Entre as principais ameaças aos polinizadores estão a perda de habitat devido a fragmentação e destruição da vegetação nativa, o uso de inseticidas na agricultura e as mudanças climáticas. O objetivo desta tese foi verificar como as abelhas nativas polinizadoras do tomateiro respondem a esses fatores de risco ambiental. O capítulo I apresenta a influência do contexto da paisagem na abundância de abelhas nativas polinizadoras do tomateiro. Para verificar a influência do contexto da paisagem amostrou-se a abundância de visitas de abelhas às flores do tomateiro em 10 cultivos de tomate convencional estaqueado em campo aberto em 2010 e 14 cultivos de tomate em 2011 e mensuraram-se as variáveis preditoras: proporção de vegetação nativa, tamanho relativo do maior fragmento e a distância entre o cultivo e a vegetação nativa mais próxima. As espécies amostradas foram incluídas em cinco grupos de acordo com a similaridade morfológica e ecológica. Abelhas de tamanho corporal menor responderam em escalas menores enquanto abelhas de tamanho corporal maior responderam em escalas maiores. A abundância de todos polinizadores juntos (buzzers), do grupo Exomalopsis e Centris aumentaram com a cobertura de vegetação nativa. A maioria dos grupos apresentaram maiores abundâncias em paisagens mais fragmentadas. Não houve relação entre a distância dos fragmentos de vegetação nativa e a abundância para nenhum dos grupos. O capítulo II apresenta a avaliação da genotoxicidade (danos ao DNA) dos inseticidas imidacloprid (neonicotinóide) e deltametrina (piretróide) usando o ensaio cometa para detectar danos ao DNA em células da hemolinfa, hemócitos, de indivíduos da espécie de abelha nativa Melipona quadrifasciata Lepeletier, 1836 (Hymenoptera, Apidae, Meliponini) em condições de 
laboratório. Para avaliar a genotoxicidade (danos ao DNA) dos inseticidas imidacloprid e deltametrina, as abelhas operárias adultas foram expostas a solução de sacarose $50 \%$ acrescida de inseticida e o grupo controle foi alimentado apenas com solução de $50 \%$ de sacarose. $\mathrm{O}$ ensaio cometa e posteriormente a captura das imagens para verificação de possíveis danos ao DNA foi realizada 72 horas após a exposição aos inseticidas. Um aumento significativo de danos ao DNA (conforme indicado pelo momento da cauda de Olive) foi detectado em hemócitos de abelhas expostas a duas concentrações subletais do inseticida deltametrina quando comparados ao inseticida imidacloprid e com o controle negativo. O inseticida imidacloprid não apresentou danos ao DNA em hemócitos das abelhas expostas a duas concentrações subletais quando comparado ao controle negativo. O capítulo III apresenta a avaliação das potenciais consequências das mudanças climáticas na distribuição geográfica de cinco espécies de abelhas nativas polinizadoras do tomateiro e as alterações nas distribuições dessas espécies na área plantada de tomate no Brasil. Para avaliar as potenciais consequências das mudanças climáticas as projeções foram realizadas para o ano de 2100 em dois cenários de emissão de carbono, sendo um cenário considerado otimista, caminhos representativos de concentração (RCP) 2,6 e o outro pessimista, RCP 8,5. Projeções conjuntas foram implementadas para simular alterações na distribuição das cinco espécies de abelhas através de cinco algoritmos. A área total do cultivo foi computada em células com pelo menos $50 \%$ de adequabilidade para cada espécie e para cada cenário climático. Os resultados mostram uma redução na área de habitat adequado para as cinco espécies em ambos os cenários, sendo mais intensa no cenário pessimista. Em relação aos cultivos de tomate, em ambos os cenários, também haverá uma redução de habitat adequado para todas as espécies em áreas de plantio de tomate no Brasil. Os resultados do presente estudo sugerem que o desmatamento, os inseticidas e as mudanças climáticas 
podem afetar negativamente a abundância, a permanência e a distribuição espacial futura de abelhas nativas polinizadoras associadas aos cultivos de tomate.

Palavras-chave: Fragmentação, perda de habitat, conservação, ensaio cometa, imidacloprid, deltametrina, genotoxicidade, mudanças climáticas, projeções, habitat, adequabilidade. 


\section{Introdução geral}

\section{Biodiversidade e os serviços ecossistêmicos}

A biodiversidade tem um papel importante no bem-estar do ser humano ao prover produtos básicos e serviços ecossistêmicos (Costanza et al. 1997; Daily 1997; Kearns et al. 1998; Alho 2012). Os serviços ecossistêmicos são processos naturais que garantem a sobrevivência das espécies no planeta e têm a capacidade de prover bens e serviços que satisfazem as necessidades humanas (De Groot et al. 2002). A biodiversidade influencia os serviços ecossistêmicos por afetar a magnitude, o ritmo, a continuidade temporal pelo qual a energia e os materiais são distribuídos ao longo dos ecossistemas e também através de seus atributos, tais como composição, riqueza, abundância entre outros (Díaz et al. 2006).

Num estudo de revisão sobre os atributos da biodiversidade e os serviços ecossistêmicos avaliados verificou se que a maioria das relações foram positivas (Harrison et al. 2014). Por exemplo, a abundância se relacionou positivamente com os serviços ecossistêmicos de controle de pragas, polinização e recreação e a riqueza de espécies com a produção de madeira e pesca (Harrison et al. 2014). Estudos têm demonstrado que o serviço de polinização é mais produtivo e tem maior estabilidade em cultivos agrícolas com maior riqueza e/ou abundância de polinizadores (Klein et al. 2007; Ricketts et al. 2008; Winfree \& Kremen 2009, Kleijn 2015). Contudo, a biodiversidade e os serviços ecossistêmicos em paisagens dominadas por atividades humanas estão sob crescente ameaça e com base nas evidências disponíveis não podemos definir um nível de perda de biodiversidade que seja seguro (Millenium 2005, Díaz et al. 2006). 


\section{Polinização e sua importância}

A polinização é essencial para a maioria das angiospermas e é um serviço ecossistêmico importante em muitos cultivos agrícolas (Williams 1994; Roubik 1995; Kearns et al. 1998; Garibaldi et al. 2016). A polinização é a transferência de grãos de pólen das anteras de uma flor para o estigma da mesma flor ou para uma outra flor da mesma espécie. Embora a polinização possa acontecer através de agentes abióticos (água e vento), os vetores bióticos são responsáveis pela polinização da grande maioria das angiospermas (Ollerton et al. 2011b).

Uma ampla variedade de organismos pode atuar como polinizadores, tais como aves, morcegos, outros mamíferos e insetos (Willmer 2011), sendo estes últimos os mais comuns (Kearns et al. 1998). Estimativas indicam que a dispersão de pólen feita por animais, principalmente insetos, contribui para a reprodução sexuada de aproximadamente 90\% das 250.000 espécies conhecidas de angiospermas (Bawa 1990, Kearns et al. 1998). Dentre estes organismos se destacam as abelhas como principal grupo de polinizadores (Delaplane \& Mayer 2000)

Klein et al. (2007) mostraram que 87 das 115 principais espécies cultivadas no mundo se beneficiam significativamente da polinização por animais, o que representa $35 \%$ da produção global de alimentos. Os serviços de polinização global foram avaliados em US\$ 200 bilhões por ano (Costanza et al. 1997) e no Brasil em US\$ 12 bilhões (Giannini et al. 2015). Apesar disso, o declínio dos polinizadores, em especial das abelhas, registrado em vários estudos pode colocar em risco os serviços de polinização, a produção de alimentos, a reprodução de espécies de plantas nativas e cultivadas, a manutenção global da biodiversidade e o funcionamento dos ecossistemas (Kearns et al. 1998; Klein et al. 2007). 


\section{Declínio de abelhas polinizadoras}

Há evidências do declínio das populações de insetos polinizadores, principalmente abelhas, em diferentes partes do mundo (Kearns et al. 1998; Potts et al. 2010; Goulson et al. 2015; Potts et al. 2015). Embora haja registros desse declínio na Ásia e América do Sul (Goulson et al. 2015), os dados mais consistentes vêm de estudos realizados nos Estados Unidos e Europa (Steffan-Dewenter et al. 2005; Fitzpatrick et al. 2007; VanEngelsdorp et al. 2008; Grixti et al. 2009; Bommarco et al. 2011; Cameron et al. 2011; Dupont et al. 2011).

Biesmeijer et al. (2006) verificaram uma relação entre o declínio das abelhas nativas na Grã-Bretanha e na Holanda e a alteração na abundância relativa das plantas polinizadas por abelhas por plantas polinizadas por moscas. Em 11 países da Europa, 27,4\% da fauna de abelhas está na lista de espécies ameaçadas de extinção (SteffanDewenter et al. 2005). Metade das espécies de mamangavas (bumble bees) desapareceu da região Centro-Oeste da América do Norte e quatro espécies do genêro Bombus já foram extintas (Grixti et al. 2009). Para a espécie domesticada Apis melífera, as perdas de colônias chegam a $25 \%$ na Europa Central e $59 \%$ na America do Norte (VanEngelsdorp et al. 2008; Goulson et al. 2015). Além desse declínio, várias espécies se encontram ameaçadas na Europa, América e em outras partes do mundo (SteffanDewenter et al. 2005; Freitas et al. 2009; Potts et al. 2010; Ministerio do Meio Ambiente 2015).

Na América do Sul, na região da Patagônia (Sul da Argertina e Chile) a invasão da espécie de abelha europeia Bombus terrestris tem levado ao declínio da espécie nativa B. dahlbomii (Schmid-Hempel et al. 2014). No Brasil, três espécies de abelhas são consideradas ameaçadas de extinção: Exomalopsis (Phanomalopsis) atlantica; Melipona capixaba e Xylocopa (Diaxylocopa) truxali (Machado et al. 2008). Na 
realidade, esse pequeno número de espécies ameaçadas talvez reflita apenas a nossa falta de conhecimento sobre o estado de conservação desse grupo. Outras 11 espécies de abelhas indicadas para a lista de espécies ameaçadas deixaram de ser incluídas, dada a falta de informações, qualificando-as na categoria deficientes em dados (Machado et al. 2008). Entre as principais ameaças às abelhas está a perda de habitat, a fragmentação, o uso de pesticidas, as mudanças climáticas e patógenos (Kearns et al. 1998; Brown \& Paxton 2009; Potts et al. 2010).

Neste cenário de constante pressão das atividades humanas sobre a biodiversidade (Millenium 2005), entender como importantes ameaças atuam sobre as abelhas nativas em cultivos poderá contribuir para conservação da diversidade desse grupo e seus efeitos em cadeia (Daily et al. 2002). Além disso, contribuirá para um melhor aproveitamento dos seus serviços de polinização, particularmente em paisagens dominadas por atividades humanas onde estes serviços são muito demandados e ameaçados (McNeely \& Scherr 2003; Millenium 2005).

\section{Fragmentação e perda de habitat}

A fragmentação de habitat pode ser definida como o processo onde habitats contínuos são divididos ao longo do tempo em áreas ou manchas menores, de diferentes tamanhos e mais ou menos isoladas entre si (Fahrig 2003; Rambaldi \& Oliveira 2003). Tal processo pode ser resultado de fenômenos naturais, ou mais frequentemente, por perturbações antrópicas diversas. Os efeitos negativos sobre as populações animais e vegetais decorrentes da fragmentação de habitat e da perda de habitat estão bem documentados por diversas pesquisas realizadas nos últimos anos (Fahrig 2003; Rambaldi \& Oliveira 2003; Viana et al. 2012). Quantitativamente, estudos envolvendo a 
relação entre polinizadores e a perda de habitat são mais comuns do que estudos sobre os efeitos da fragmentação nesse grupo (Hadley \& Betts 2012).

A proporção de vegetação nativa, o tamanho do fragmento e a distância geográfica da vegetação nativa são parâmetros simples, porém de alto valor preditivo para determinar a abundância e a frequência de visitas dos polinizadores (Tscharntke et al. 2002a). Áreas grandes têm taxas de imigração altas, extinções baixas (MacArthur \& Wilson 1967) assim como eventos aleatórios de extinções são menos comuns do que em áreas pequenas (Shaffer 1981). Contudo, alguns estudos em paisagens fragmentadas verificaram que pequenos fragmentos são importantes, pois podem maximizar a diversidade beta e fornecer recursos cruciais para manutenção de algumas espécies, principalmente espécies com alta mobilidade (Tscharntke et al. 2002b; Rueda et al. 2013). Um declínio da riqueza e da abundância de polinizadores foram encontrados em cultivos com menor proporção de vegetação nativa no entorno e menor número de fragmentos de habitats naturais ou semi-naturais (Tscharntke et al. 2002a; Ricketts et al. 2008; Carvalheiro et al. 2010; Klein et al. 2012; Viana et al. 2012), mostrando que a vegetação nativa e o seu nível de fragmentação podem influenciar os polinizadores que visitam os cultivos agrícolas (Klein et al. 2012).

Segundo a teoria de biogeografia de ilhas, há uma diminuição da taxa de colonização em ilhas mais distantes em relação às mais próximas dos continentes (MacArthur \& Wilson 1967). Baseado nesta teoria e em outros estudos, é possível prever que cultivos mais próximos da vegetação nativa tenham maior riqueza e frequência de visitas de polinizadores do que cultivos mais distantes da vegetação nativa (Tscharntke et al. 2012). Entretanto, Ricketts et al. (2008) ressaltam que os efeitos da paisagem nos serviços de polinização podem variar substancialmente de maneiras ainda pouco entendidas, pois são altamente dependentes das características de cada espécie 
(Greenleaf \& Kremen 2006), provocando uma divergência nas respostas dependendo das espécies estudadas.

\section{Inseticidas e abelhas}

Substâncias xenobióticas introduzidas nos agroecossistemas com o intuito de controlar pragas, doenças ou plantas daninhas podem também afetar insetos não alvo, como as abelhas (Nocelli et al. 2012). Durante os últimos anos, diversos relatos evidenciam a diminuição das populações de abelhas no campo, fato esse que pode estar intimamente ligado ao uso demasiado de agrotóxicos, gerando prejuízos incalculáveis a flora, fauna e ao homem.

Em vários países da Europa o uso do inseticida do grupo dos neonicotinóides foi proibido. No entanto, sua utilização é livre em muitos outros países, incluindo os Estados Unidos, onde desde 2006, um terço da população de Apis mellifera já morreu (VanEngelsdorp et al. 2008). Vários estudos suportam a decisão de proibir o uso de inseticidas neonicotinóides devido aos seus impactos sobre abelhas (Tennekes 2010; Hayasaka et al. 2012). Outro grupo de inseticida altamente tóxico para as abelhas é o grupo dos piretróides (Inglesfield 1989; Johnson et al. 2010). No Brasil, os piretróides e os neonicotinóides são utilizados em larga escala (Latorraca et al. 2008)

Ambos os grupos de inseticidas, piretróides e neonicotinóides, atuam principalmente no sistema nervoso. Os neonicotinóides atuam na propagação do impulso nervoso competindo com a acetilcolina. E, ao contrário da ligação natural da acetilcolina com seu receptor, a ligação entre os neonicotinóides e os receptores de acetilcolina é irreversível. A ativação dos receptores de acetilcolina é prolongada de modo anormal, causando hiperexcitabilidade do sistema nervoso central devido à transmissão contínua e descontrolada de impulsos nervosos, colapso do sistema nervoso 
e morte (Faria 2009). Os piretróides atuam alterando as propriedades de propagação do íon sódio $\left(\mathrm{Na}^{+}\right)$, o qual é essencial para a geração e propagação do impulso nervoso, causando, assim, sintomas de envenenamento como hiperexcitação, ataxia, convulsões, hipersensibilidade, tremores e paralisias (Soderlund et al. 2002).

Há vários estudos ecotoxicológicos sobre os efeitos subletais de inseticidas dos grupos dos neonicotinóides, ingrediente ativo imidacloprid, e piretróides, ingrediente ativo deltametrina, no comportamento e fisiologia de abelhas (Vandame et al. 1995; Belzunces et al. 2001; Schmuck et al. 2001; Thompson 2002; Decourtye et al. 2004, 2005; Skerl \& Gregorc 2010; Gregorc \& Ellis 2011; Schneider et al. 2012) e alguns estudos de campo (Kevan 1975; Gels et al. 2002; Alston et al. 2007), mas não existem evidências de qual é a extensão dos danos genotóxicos induzidos pelos inseticidas em abelhas.

A espécie M. quadrisfacita é uma abelha eusocial, sem ferrão, exclusiva da região neotropical (Camargo \& Pedro 1992), e possui grande importância ecológica e econômica devido a sua participação na polinização de plantas nativas e cultivadas (Del Sarto et al. 2005; Antonini et al. 2006; Santos et al. 2009; Nunes-Silva et al. 2010). $M$. quadrisfacita tem se mostrado eficiente polinizador do tomateiro em cultivos protegidos e de outras espécies vegetais (Nunes-Silva et al. 2010). Sendo assim, essa espécie pode ser um importante objeto de estudo para testar a extensão dos danos genotóxicos induzidos pelos inseticidas em abelhas.

Genotoxicidade é quando uma substância tem a capacidade de reagir com o ácido desoxirribonucléico (DNA) diretamente ou após a sua ativação metabólica, produzindo danos na estrutura e/ou função do DNA (Weisburger 1999). Danos ao DNA (quebras de fitas simples, duplas, crosslinks, sitios de reparos ou por excisão e/ou lesões álcali-lábeis) representam potenciais lesões mutagênicas. O grau de integridade do DNA 
tem sido proposto como um indicador sensível de genotoxicidade para biomonitoramento de ecossistemas terrestes e aquáticos (Azqueta et al. 2015). Tendo em vista o potencial tóxico dos inseticidas e a falta de dados sobre os riscos genotóxicos que eles oferecem as abelhas, tornam-se necessários estudos mais aprofundados sobre o assunto.

Uma das técnicas utilizadas para avaliação de danos ao DNA é o ensaio cometa (eletroforese em gel de célula única) ou do inglês, "single cell gel electrophoresis" e tem sido considerada como uma das mais eficientes (Azqueta et al. 2015). É considerada de baixo custo, alta sensibilidade, fácil execução e qualquer célula eucariótica nucleada pode ser utilizada nos ensaios (Tice et al. 2000). Nesse teste, as células que apresentam um núcleo redondo são identificadas como normais, sem danos detectáveis no DNA (Quadro 1a). Por outro lado, as células lesionadas são identificadas visualmente ou através de programas computacionais por uma espécie de cauda, similar a cauda de um cometa, formada pelos fragmentos de DNA (Quadro 1b-e). Estes fragmentos podem se apresentar em diferentes tamanhos (Quadro 1b-e), e ainda estar associados ao núcleo por uma cadeia simples. Para alguns autores, o tamanho da cauda é proporcional à dimensão do dano que foi causado, mas é de consenso que a simples visualização do “cometa” já significa que danos estão presentes no DNA (Silva 2007). 


\begin{tabular}{|c|c|c|}
\hline Imagem Observada & Cauda/Cabeça & Classes de Danos \\
\hline a) & $\begin{array}{c}\text { sem cauda } \\
\text { normal }\end{array}$ & 0 \\
\hline b) & $\begin{array}{c}\leq 1 \\
\text { lesionada }\end{array}$ & 1 \\
\hline c) & $\begin{array}{c}1-2 \\
\text { lesionada }\end{array}$ & 2 \\
\hline d) & $\begin{array}{c}\geq 2 \\
\text { lesionada }\end{array}$ & 3 \\
\hline e) & $\begin{array}{c}\text { sem cabeca } \\
\text { lesionada }\end{array}$ & 4 \\
\hline
\end{tabular}

Quadro 1. Classificação das imagens das “células cometa”. Fonte: Silva 2007.

\section{Mudanças climáticas e abelhas}

Uma vasta gama de estudos indica que as mudanças climáticas são um dos maiores fatores de pertubação antrópica imposta ao ecossistema (Parmesan 2006; Walther et al. 2002) e uma das maiores ameaças à biodiversidade no século 21 ( Araújo et al. 2004; Brook et al. 2008; Leadley et al. 2010). As alterações climáticas têm produzido numerosas mudanças nas distribuições e abundância de espécies (Root et al. 2003; Parmesan \& Yohe 2003) e afetado a fenologia de insetos e plantas (Memmott et al. 2007; Hegland et al. 2009; Hoover et al. 2012). Outro problema grave é que as mudanças climáticas podem causar desencontros espaciais e temporais entre os polinizadores e as plantas que visitam devido a mudanças diferenciais nas áreas de distribuição e fenologia das espécies que interagem entre si (Memmott et al. 2007; Hegland et al. 2009; Polce et al. 2014).

Embora tenha havido um aumento no número de estudos envolvendo o aquecimento global e a fenologia de insetos e plantas, alguns estudos de revisão têm 
indicado que o conhecimento sobre este assunto ainda é limitado (Walther et al. 2002; Visser \& Both 2005). Quando o assunto envolve os polinizadores, os serviços ecossistêmicos e as mudanças climáticas as lacunas são ainda maiores (Hegland et al. 2009; Giannini et al. 2012). Isso é preocupante, pois os polinizadores são considerados peças fundamentais para a biodiversidade global e a polinização realizada por eles é vital para os sistemas naturais e para a agricultura (Daily 1997).

As mudanças climáticas podem afetar o serviço ecossistêmico de polinização através dos seus efeitos sobre os polinizadores. Os impactos das mudanças climáticas sobre os insetos são frequentemente estudados em escala temporal (Sparks \& Yates 1997) ou em escala espacial, como por exemplo, as mudanças nas distribruições geográficas das espécies (Parmesan 2006). Uma vez que os insetos são ectotérmicos (Willmer \& Unwin 1981) até mesmo pequenas mudanças de temperatura podem alterar sua atividade e comportamento de forrageio (Heard \& Hendrikz 1993; Stone 1994). Embora haja uma relação positiva entre a temperatura e a atividade de polinizadores nas flores (Willmer \& Stone 2004), importantes polinizadores, como as abelhas, podem alcançar altos limiares de temperatura e passar mais tempo resfriando o corpo e menos tempo forrageando (Heinrich 1979; Cooper et al. 1985).

O Painel Intergovernamental para as Mudanças Climáticas (IPCC) da Organização das Nações Unidas (ONU) criou quatro projeções de cenários futuros de forçantes radioativas, os RCPs - Caminhos Representativos de Concentrações. São eles o RCP 2,6; RCP 4,5; RCP 6,0 e RCP 8,5. O termo "representativos" significa que cada RCP fornece apenas um dos muitos cenários possíveis que levaria para características específicas do forçamento radioativo. A palavra "caminhos" enfatiza que não só os níveis de concentração a longo prazo são de interesse, mas também a trajetória tomada ao longo do tempo para chegar a esse resultado (Moss et al. 2010). 
No cenário RCP 2,6, considerado um cenário otimista, o forçamento radioativo ficará em torno de $3 \mathrm{~W} \mathrm{~m}^{-2}$ (watt por metro quadrado) e a concentração de $\mathrm{CO}_{2}$ equivalente atingirá um pico de cerca de 490 ppm (partes por milhão) antes de 2100 e então declinará. No RCP 4,5 o forçamento radioativo será aproximadamente de 4,5 W $\mathrm{m}^{-2}$ e a concentração de $\mathrm{CO}_{2}$ equivalente ficará em torno de $650 \mathrm{ppm}$. No RCP 6,0 o forçamento radioativo ficará em torno de $6,0 \mathrm{~W} \mathrm{m-{ } ^ { 2 }}$ e a concentração de $\mathrm{CO}_{2}$ equivalente ficará em torno de 850 ppm e no RCP 8,5, considerado um cenário pessimista, o forçamento radioativo é maior que $8,5 \mathrm{~W} \mathrm{~m}^{-2}$ e a concentração de $\mathrm{CO}_{2}$ equivalente maior que $1.370 \mathrm{ppm}$ (Moss et al. 2010).

Um cenário preocupante em relação às mudanças climáticas futuras sobre as abelhas e alguns serviços ecossistêmicos foi demostrado em alguns estudos realizados na Europa, América do Norte, África (Kuhlmann et al. 2012; Rader et al. 2013; Polce et al. 2014) e na América do Sul (Giannini et al. 2012; Giannini et al. 2013).

Na Europa, as projeções futuras para 2050 mostram que a maioria das áreas adequadas para cultivos de maçãs, cerejas, peras, ameixas e nozes terão baixa disponibilidade de polinizadores devido ao desencontro entre os cultivos e os polinizadores (Polce et al. 2014). Na América do Norte, o serviço ecossistêmico realizado por Apis mellifera Linnaeus, 1758, em cultivos de melancia em 2099 deixará de existir e passará a ser realizado apenas por espécies de abelhas nativas devido a inadequabilidade climática para persistência dessa espécie na região dos cultivos (Rader et al. 2013). Na África, em uma região considerada de alto endemismo de abelhas, Kuhmman et al. (2012) verificaram que haverá contrações nas áreas de distribuição para as 12 espécies estudadas em maior ou menor extensão dependendo da espécie.

No Brasil, dois estudos também mostram efeitos negativos das mudanças climáticas na distribuição de espécies de abelhas e plantas nativas associadas a essas 
espécies. No primeiro estudo, nove das 10 espécies de abelhas nativas estudadas sofrerão redução na área de habitat adequado no futuro. De acordo com o segundo estudo, ocorrerá uma redução nas áreas de habitat adequados para a maioria das abelhas polinizadoras do maracujá, Passiflora edulis Sims, e para as plantas nativas associadas a esses polinizadores (Giannini et al. 2012; Giannini et al. 2013).

Uma questão que se torna relevante é entender como as mudanças climáticas podem afetar a distribuição das espécies de abelhas e, consequentemente como os serviços de polinização poderiam ser prejudicados em termos de área plantada devido a potencial ausência de polinizadores nos cultivos no futuro.

\section{Modelagem de nicho}

O surgimento dos bancos de dados com grandes coleções biológicas informatizadas, a tecnologia do Sistema de Informação Geográfica - GIS -acessível aos ecólogos e biogeógrafos e o desenvolvimento dos modelos bioclimáticos permitiram que os modelos de "nicho" ecológico fossem utilizados para estimar a "distribuição geográfica” das espécies, seja potencial ou real (Soberón 2007).

A modelagem de distribuição potencial tem sido amplamente utilizada para a conservação de espécies raras ou ameaçadas, para a avaliação do potencial invasivo de espécies exóticas, para estudos de impactos das mudanças climáticas e estudos das possíveis rotas de disseminação de doenças infecciosas, entre outros (De Marco \& Siqueira 2009; Peterson et al. 2011). Na maior parte das aplicações se considera que o nicho ecológico é o modelo básico que sustenta a possibilidade de produzir predições sobre a ocorrência de espécies (Peterson 2001; Thuiller et al. 2005; Elith et al. 2006).

Joseph Grinell foi o primeiro naturalista a definir nicho sob uma perspectiva ambiental e geográfica, em que o nicho seria determinado pelas 
condições/requerimentos ambientais sob os quais uma espécie consegue sobreviver (Grinell 1917). Charles Elton, uma década depois, propôs um conceito de nicho baseado nas interações bióticas, no qual o nicho determina o papel funcional da espécie em uma comunidade, de acordo com o impacto gerado sobre as outras espécies e com o impacto recebido (Elton 1927). Para George E. Hutchinson, o nicho é composto de duas facetas básicas, nicho fundamental e o realizado, refletindo processos diferentes sobre a existência de uma espécie. O nicho fundamental reflete todas as condições ambientais em que a espécie consegue sobreviver, e o nicho realizado é reflexo dos impactos dados pelas interações bióticas negativas, como competição e predação, sobre as condições que a espécie consegue sobreviver (Hutchinson 1957). Em nosso estudo, o conceito de nicho utilizado será o conceito de nicho de Joseph Grinell e o conceito de Hutchinson no que diz respeito ao sub-espaço de condições (ou cenopoético) e não o sub-espaço de recursos, pois os dados ambientais disponíveis representam o sub-espaço de condições e não a interação entre as espécies (De Marco \& Siqueira 2009).

A ferramenta de modelagem ecológica utiliza variáveis ambientais e climáticas do lugar onde se registrou a ocorrência das espécies para construir um modelo do nicho utilizado por elas em todos os pontos de ocorrência conhecidos. A partir desse modelo, ela projeta as condições ambientais propícias para a ocorrência das espécies para locais em que esta não é conhecida e gera um mapa de distribuição potencial ao longo da área considerada. A partir das variáveis analisadas no treino do modelo, a análise também pode extrapolar a ocorrência das espécies em outros períodos de tempo ou em outras regiões geográficas (Oliveira 2015).

Há uma diversidade enorme de modelos com diferentes concepções e que utilizam diferentes parâmetros (Elith et. al. 2006; Qiao et. al. 2015). A seleção de um modelo apropriado pode ser feita com base no conhecimento da espécie a ser modelada 
ou através da projeção conjunta de vários modelos (Peterson et al. 2011; Araújo \& New 2007). A previsão da distribuição das espécies com o uso do consenso de vários modelos reduz as incertezas próprias de cada modelo e melhora a precisão da previsão (Araújo \& New 2007). Sendo assim, em nosso estudo optamos pela previsão da distribuição das espécies através da projeção conjunta de cinco modelos com intuito de reduzir as incertezas de cada modelo e melhorar a precisão da previsão.

\section{Bioma Cerrado e os cultivos de tomate}

O Cerrado é um dos "hotspots" com prioridades de conservação, possui uma das floras mais rica das savanas (> 7.000 espécies) com alto grau de endemismo (Myers et al. 2000). Depois da Amazônia, o Cerrado brasileiro destaca-se como o segundo maior bioma em extensão territorial (cerca de $20 \%$ do território nacional).

Historicamente, o Cerrado vem sofrendo impactos antrópicos que contribuem para a perda da cobertura vegetal original. Tal transformação torna possível relacionar o aumento da produtividade agrícola do Cerrado nos últimos 30 anos, concomitantemente com a redução de suas reservas naturais, restando atualmente apenas pequenas manchas do Cerrado original, sendo raro ver alguma área preservada (Lima 1996).

No bioma Cerrado se encontram presentes mais de 1/3 da produção nacional de tomate (Brito \& Melo 2010). O tomateiro é uma das hortaliças com maior volume de produção no Brasil, com mais de quatro milhões de toneladas produzidas em 2013 (IBGE 2015). É a espécie mais cultivada da família Solanaceae, sendo denominada Solanum lycopersicum. As flores, pequenas e amarelas, são hermafroditas, costumam ocorrer em monocásios de 3 a 12 flores (Fontes \& Silva 2002), os estames formam um tubo em torno do pistilo. Solanum lycopersicum possui sistema reprodutivo autocompatível, mas dependente da visita de abelhas polinizadoras para melhorar a 
qualidade e quantidade de frutos e sementes (McGregor 1976; Melo-Silva et al. 2013; Deprá et al. 2014). Em um levantamento realizado em 14 plantações do estado de Goiás foi registrada a presença de 26 espécies de abelhas nativas visitando as flores do tomateiro. As espécies de abelhas nativas mais frequentes e capazes de realizar essa polinização foram: Exomalopsis analis, Exomalopsis auropilosa, Augochloropsis sp., Centris tarsata, Bombus sp e Eulaema nigrita (Silva-Neto et. al. no prelo).

A cultura do tomateiro exige altos investimentos em adubação, tratos culturais e proteção fitossanitária. Os vários problemas fitossanitários (patógenos, ácaros e insetos praga) que atingem o tomateiro levam o produtor ao uso preventivo, exagerado e indevido de agrotóxicos (Reis-Filho et al. 2009). No estado de Goiás, estes produtores usam vários tipos de inseticidas, sendo os mais vendidos para as plantações de tomate em Goiânia e Goianápolis os dos grupos químicos organofosforados, piretróides e neonicotinóides (Latorraca et al. 2008), todos tóxicos para uma ampla gama de animais.

O cultivo do tomateiro configura-se como um sistema interessante para testar qual a influência da paisagem, a genotoxicidade dos inseticidas e o potencial efeito das mudanças climáticas futuras em abelhas nativas associadas a esses cultivos devido a alta riqueza e frequência de polinizadores nativos, a sua grande importância econômica para o Brasil e a alta quantidade de agrotóxicos utilizados.

\section{Objetivo geral}

O objetivo geral desta tese foi verificar como as abelhas nativas polinizadoras do tomateiro se relacionam ou são afetadas pelas principais ameaças impostas a esse grupo no presente e no futuro. "No presente", buscamos avaliar: 1) a influência do contexto da paisagem na abundância de abelhas nativas polinizadoras do tomateiro; 2) a genotoxicidade de dois inseticidas, o imidacloprid, do grupo dos neonicotinóides e a 
deltametrina, do grupo dos piretróides, no DNA de células da hemolinfa de abelhas $M$. quadrifasciata usando a técnica do ensaio cometa. "No futuro", buscamos avaliar: 3) as possíveis alterações na distribuição geográfica de cinco espécies de abelhas nativas polinizadoras do tomateiro e quanto dessas alterações acontecerão em áreas plantadas de tomate no Brasil como consequências das mudanças climáticas em 2100.

\section{Objetivos específicos}

1.1) Verificar se em locais com maior proporção de vegetação nativa encontra-se uma maior abundância de abelhas nativas nos cultivos de tomate.

1.2) Verificar se há relação entre fragmentação: tamanho relativo do maior fragmento (RLPs) e a abundância de abelhas nativas nos cultivos de tomate.

1.3) Testar se a distância dos remanescentes de vegetação nativa afeta a abundância de abelhas nativas polinizadoras do tomateiro.

2.1) Verificar se há diferenças significativas entre os danos ao DNA em células da hemolinfa da M. quadrifasciata causados pelos inseticidas imidacloprid, do grupo dos neonicotinóides e o deltametrina, do grupo dos piretróides.

2.2) Verificar se há diferenças significativas entre o controle negativo e os tratamentos em relação aos danos ao DNA em células da hemolinfa de $M$. quadrifasciata causados pelos inseticidas imidacloprid e deltametrina.

3.1) Verificar se haverá alterações nas áreas de habitat adequado para as cinco principais espécies de abelhas nativas polinizadoras do tomateiro em dois cenários de mudanças climáticas, um mais otimista e outro mais pessimista, para o ano de 2100 se comparado com o cenário presente.

3.2) Mensurar a concordância entre áreas de habitat adequado para estas cinco espécies de abelhas nativas e as áreas de plantio de tomate no Brasil no presente e 
futuro, considerando que a área plantada de tomate na atualidade continue a mesma nos dois cenários futuros para o ano de 2100 .

\section{Referências Bibliográficas}

Alho, C.J.R. (2012) Importância da biodiversidade para a saúde humana: uma perspectiva ecológica. Estudos Avançados, 26, 151-166.

Alston, D.G., Tepedino, V.J., Bradley, B.A., Toler, T.R., Griswold, T.L., Messinger, S.M. (2007) Effects of the insecticide phosmet on solitary bee foraging and nesting in orchards of Capitol Reef National Park, Utah. Environmental Entomology, 36, $811-816$.

Antonini, Y., Soares, S.M., Parentoni, R.M. (2006) Pollen and nectar harvesting by the stingless bee Melipona. quadrifasciata anthidioides (Apidae: Meliponini) in an urban forest fragment in Southeastern Brazil. Studies Neotropical Fauna and Environment, 41, 209 - 215.

Araújo, M.B., Cabeza, M., Thuiller, W., Hannah, L., Williams, P.H. (2004) Would climate change drive species out of Reserves? An assessment of existing reserve-selection methods. Global Change Biology, 10, 1618-1626.

Araújo, M.B., New, M. (2007). Ensemble forecasting of species distributions. Trends in Ecology and Evolution, 22, 42-47.

Azqueta, A., Langie, S., Collins, A., eds. (2015). 30 years of the comet assay: an overview with some new insights. Lausanne: Frontiers Media.

Bawa, K. Plant pollinator interactions in tropical rain forests (1990) Annual Review of Ecology and Systematics, 21, 399 - 422. 
Biesmeijer, J.C., Roberts, S.P.M., Reemer, M., Ohlemüller, R., Edwards, M., Peeters, T., Schaffers, A.P., Potts, S.G., Kleukers, R., Thomas, C.D., Settele, J., Kunin, W.E. (2006) Parallel declines in pollinators and insect-pollinated plants in Britain and the Netherlands. Science, 313, 351-354.

Belzunces, L.P., Vandame, R., Xingfa, G.U. (2001) Joint effects of pyrethroid insecticides and azole fungicides on honey-bee thermoregulation. In: Belzunces, L.P., Pelissier, C., Lewis, G.B. (Eds.). Hazard of pesticides to bee. Avignon: INRA, 2001, Paris, 297-298 p.

Bommarco, R., Lundin, O., Smith, H.G., Rundlöf, M. (2011) Drastic historic shifts in bumble-bee community composition in Sweden. Proceedings of the Royal Society B-Biological Sciences, 279, 309-315.

Brito, L., Melo, L. (2010) A produção mundial e brasileira de tomate. DIEESEGoiânia: DIEESE - Departamento Intersindical de Estatística e Estudos Socioeconômicos Disponível

em: https://www.dieese.org.br/projetos/informalidade/estudoSobreAproducaoDeTom ateIndustrialNoBrasil.pdf >. Acesso em: 23 outubro de 2015.

Brook, B.W., Sodhi, N.S., Bradshaw, C.J.A. (2008) Synergies among extinction drivers under global change. Trends in Ecology and Evolution, 23, 453-460.

Brown, M.J.F., Paxton, R.J. (2009) The conservation of bees: a global perspective. Apidologie, 40, 410-416.

Burd, M. (1994) Bateman principle and plant reproduction - the role of pollen limitation in fruit and seed set. Botanical Review, 60, 83-139.

Camargo, J.M.F., Pedro, S.R.M. (1992) Systematics, phylogeny and biogeography of the Meliponinae (Hymenoptera, Apidae): a minireview. Apidologie, 23, 509522. 
Cameron, S.A., Lozier, J.D., Strange, J.P., Koch, J.B., Cordes, N., Solter, L.F., Griswold, T.L. (2011) Patterns of widespread decline in North American bumble bees. Proceedings of the National Academy of Sciences of the United States of America, 108, 662-667.

Carvalheiro, L.G., Seymour, C.L., Veldtman, R., Nicolson, S.W. (2010) Pollination services decline with distance from natural habitat even in biodiversity-rich areas. Journal of Applied Ecology, 47, 810-820.

Cooper, P.D., Schaffer, W.M., Buchmann, S.L (1985) Temperature regulation of honey bees (Apis mellifera) foraging in the Sonoran desert. Journal of Experimental Biology, 114, 1-15.

Costanza, R., D'Arge, R., Groot, R., Farber, S., Grasso, M., Hannon, B., Limburg, K., Naeem, S., O'neill, R.V., Paruelo, J., Raskin, R.G., Sutton, P., Belt, M. V. D. (1997) The value of the world's ecosystem services and natural capital. Nature, 38, 253-260.

Daily, G.C. (1997) Nature's services: societal dependence on natural ecosystems. Island Press, Washington, DC, 412 p.

Daily, G., Ellison, K. (2002) The new economy of nature. Island Press Washington, DC, $250 \mathrm{p}$.

Decourtye A., Devillers J., Cluzeau S., Charreton M., Pham-Delegue M. H. (2004) Effects of imidacloprid and deltamethrin on associative learning in honeybees under semi-field and laboratory conditions. Ecotoxicology and Environmental Safety, 57, 410-419. 
Decourtye, A., Devillers, J., Genecque, E, Le Menach, K., Budzinski, H., Cluzeau, S., Pham-Delegue, M.H. (2005) Comparative sublethal toxicity of nine pesticides on olfactory learning performances of the honeybee Apis mellifera. Archives of Environmental Contamination Toxicology, 48, 242-250.

De Groot, R.S., Wilson, M.A., Boumans, R.M.J. (2002) A typology for the classification, description and valuation of ecosystem functions, goods and services. Ecological Economics, 41, 393-408.

Del Sarto, M.C.L., Peruquetti, R.C., Campos, L.A.O. (2005) Evaluation of the neotropical bee Melipona quadrifasciata (Hymenoptera: Apidae) as pollinator of greenhouse tomatoes. Journal of Economic Entomology, 98, 260-266.

Delaplane, K.S., Mayer, D.F. (2000) Crop pollination by bees. CABI Publishing, New York, $364 \mathrm{p}$.

De Marco-Júnior, P., Siqueira, M.F. (2009) Como determinar a distribuição potencial de espécies sob uma abordagem conservacionista? Megadiversidade, 5, 65-76.

Deprá, M.S., Delaqua, G.C.G., Freitas, L., Gaglianone, M.C. (2014) Pollination deficit in open-field tomato crops (Solanum lycopersicum L., Solanaceae) in Rio de Janeiro state, Southeast Brazil. Journal of Pollination Ecology, 12 , 1-8.

Díaz, S., Fargione, J., Chapin III, F.S., Tilman, D. (2006) Biodiversity loss threatens human well-being. PLoS Biol. 4, 1300-1305.

Dupont, Y.L., Damgaard, C., Simonsen, V. (2011) Quantitative historical change in bumblebee (Bombus spp.) assemblages of red clover fields. PLoS ONE, 6, e25172.

Elias, M.A.S. (2016) Ameaças da perturbação antrópica a abelhas nativas polinizadoras do tomateiro. Brasília, UNB, Tese, Doutorado em Ecologia, 171 p. 
Elith, J; Graham, C.H., Anderson, R.P., Dudik, M., Ferrier, S., Guisan, A., Hijmans, R.J., Huettmann, F., Leathwick, J.R., Lehmann, A., Li, J., Lohmann, L.G., Loiselle, B.A., Manion, G., Moritz, C., Nakamura, M., Nakazawa, Y., Overton, J.M., Peterson, A.T., Phillips, S.J., Richardson, K., Scachetti-Pereira, R., Schapire, R.E., Soberon, J., Williams, S., Wisz, M.S., Zimmermann, N.E. (2006) Novel methods improve prediction of species distributions from occurrence data. Ecography, 29, 129-151.

Elton, C. (1927) Animal Ecology. Sidgwick \& Jackson, London UK, 204 p.

Fahrig, L. (2003) Effects of habitat fragmentation on biodiversity. Annual Review of Ecology, Evolution and Systematics, 34, 487-515.

Fahrig, L., Baudry, J., Brotons, L., Burel, F.G., Crist, T.O., Fuller, R.J., Sirami, C., Siriwardena, G.M., Martin, J.L. (2011) Functional landscape heterogeneity and animal biodiversity in agricultural landscapes. Ecology Letters, 14, 101-112.

Faria, A.B.C. (2009) Revisão sobre alguns grupos de inseticidas utilizados no manejo integrado de pragas florestais. Ambiência - Revista do Setor de Ciências Agrárias e Ambientais, 5, 345-358.

Fitzpatrick, U., Murray, T.E., Paxton, R.J., Breen, J., Cotton, D., Santorum, V., Brown, M.J.F. (2007) Rarity and decline in bumblebees - A test of causes and correlates in the Irish fauna. Biological Conservation, 136, 185-194.

Fontes, P., Silva, D. (2002) Produção de tomate de mesa. Aprenda Fácil Editora, Viçosa, 193 p.

Freitas, B.M., Imperatriz-Fonseca, V.L., Medina, L.M., Kleinert, A.M.P., Galetto, L., Nates-Parra, G., Quezada-Euán, J.J.G.(2009) Diversity, threats and conservation of native bees in the Neotropics. Apidologie, 40, 332-346. 
Garibaldi et al. (2016) Mutually beneficial pollinator diversity and crop yield outcomes in small and large farms . Science, 351, 388-391.

Gels, J.A., Held, D.W., Potter, D.A. (2002) Hazards of insecticides to the bumble bees Bombus impatiens (Hymenoptera: Apidae) foraging on flowering white clover in turf. Journal of Economic Entomology, 95, 722 - 728.

Giannini, T.C., Cordeiro, G.D., Freitas, B.M., Saraiva, A.M., Imperatriz-Fonseca, V.L. (2015) The Dependence of crops for pollinators and the economic value of pollination in Brazil. Journal of Economic Entomology, 108,849-857

Giannini, T.C., Acosta, A.L., Silva, C.I., Oliveira, P.E.A.M., Imperatriz-Fonseca, V.L., Saraiva, A.M. (2013) Identifying the areas to preserve passion fruit pollination service in brazilian tropical savannas under climate change. Agriculture, Ecosystems \& Environment, 171:39-46.

Giannini, T.C., Acosta, A.L., Garófalo, C.A., Saraiva, A.M., Alves-dos-Santos, I., Imperatriz-Fonseca, V.L. (2012) Pollination services at risk: Bee habitats will decrease owing to climate change in Brazil. Ecological Modelling, 244,127-131.

Goulson, D., Nicholls, E., Botías, C., Rotheray, E.L. (2015) Bee declines driven by combined stress from parasites, pesticides, and lack of flowers. Science. <http://www.sciencemag.org/cgi/doi/10.1126/science.1255957> Acesso em: 05 de abril de 2015.

Greenleaf, S.S., Kremen, C. (2006) Wild bee species increase tomato production and respond differently to surrounding land use in Northern California. Biological Conservation, 13, 81-87.

Gregorc, A., Ellis, J. (2011) Cell death in situ in laboratory reared honey bee (Apis mellifera L.) larvae treated with pesticides. Pesticide Biochemistry and Physiology, 99, 200-207. 
Grinnell, J. (1917) The niche relationships of the california thrasher. Auk, 34, 427-433.

Grixti, J.C., Wong, L.T., Cameron, S.A., Favret, C. (2009) Decline of bumble bees (Bombus) in the North American Midwest. Biological Conservation, 142, 75-84.

Hadley, A.S., Betts, M.G. (2012) The effects of landscape fragmentation on pollination dynamics: absence of evidence not evidence of absence. Biological Reviews, 87, $526-544$.

Harrison, P.A., Berry, P.M., Simpson, G., Haslett, J.R., Blicharska, M., Bucur, M., Dunford, R., Egoh, B., Garcia-Llorente, M., Geamănă, N., Geertsema, W., Lommelen, E., Meiresonne, L., Turkelboom, F. (2014) Linkages between biodiversity attributes and ecosystem services: a systematic review. Ecosystem Services, 9,191-203.

Hayasaka, D., Korenaga, T., Sánchez-Bayo, F., Goka, K. (2012) Differences in ecological impacts of systemic insecticides with different physicochemical properties on biocenosis of experimental paddy fields. Ecotoxicology, 21, 191201.

Heard, T.A., Hendrikz, J.K. (1993) Factors influencing flight activity of colonies of the stingless bee Trigona carbonaria (Hymenoptera, Apidae). Australian Journal of Zoology, 41, 343-353.

Hegland, S.J., Nielsen, A., Lázaro, A., Bjerknes, A.L., Totland, Ø. (2009) How does climate warming affect plant-pollinator interactions? Ecolgy Letters, 12,184195.

Heinrich, B. (1979) Keeping a cool head: honeybee thermoregulation. Science, 205, $1269-1271$. 
Hoover, S.E.R., Ladley, J.J., Shchepetkina, A.A., Tisch, M., Gieseg, S.P., Tylianakis, J.M. (2012) Warming, CO2, and nitrogen deposition interactively affect a plantpollinator mutualism. Ecology Letters, 15, 227-234.

Hutchinson, G.E. (1957) Concluding remarks. Cold Spring Harbor Symposium of Quantitative Biology, 22, 415-427.

Inglesfield, C. (1989) Pyrethroids and terrestrial non-target organisms. Pesticide Science, 27, 387-428.

Instituto Brasileiro de Geografia e Estatística (2015) Sistema IBGE de Recuperação Automática - SIDRA. Disponível em: <http://www.sidra.gov.br/bda/tabela /listabl.asp>. Acesso em: 12 de junho de 2015.

Intergovernmental Panel on Climate Change (2014) Climate Change 2014: Synthesis report. Contribution of Working Groups I, II and III to the Fifth Assessment Report of the Intergovernmental Panel on Climate Change [Core Writing Team, R.K. Pachauri and L.A. Meyer (eds.)]. IPCC, Geneva, Switzerland, 151 p.

Johnson, R.M., Ellis, M.D., Mullin, C.A., Frazier, M., Johnson, R.M., Ellis, M.D., Mullin, C.A., Frazier, M. (2010) Pesticides and Honey Bee Toxicity - USA. Apidologie, 41, 312-331.

Kearns, C.A., Inouye, D.W., Waser, N.M. (1998) Endangered mutualisms: The Conservation of Plant-Pollinator Interactions. Annual Review of Ecology and Systematics, 29, 83-112.

Kevan, P.G. (1975) Forest application of the insecticide fenitrothion and its effect on wild bee pollinators (Hymenoptera: Apoidea) of lowbush blueberries (Vaccinium spp.) in Southern New Brunswick, Canada. Biological Conservation, 7, $301-309$. 
Kleijn, D., Winfree, R., Bartomeus, I., Carvalheiro, L.G., Henry, M., Isaacs, R., Klein, A-M., Kremen, C., M’Gonigle, L.K., Rader, R., Ricketts, T.H., Williams, N.M., Adamson, N.L., Ascher, J.S., Báldi, A., Batáry, P., Benjamin, F., Biesmeijer, J.C., Blitzer, E.J., Bommarco, R., Brand, M.R., Bretagnolle, V., Button, L., Cariveau, D.P., Chifflet, R., Colville, J.F., Danforth, B.N., Elle, E., Garratt, M.P.D., Herzog, F., Holzschuh, A., Howlett, B.G., Jauker, F., Jha, S., Knop, E., Krewenka, K.M., Le Féon, V., Mandelik, Y., May, E.A., Park, M.G., Pisanty, G., Reemer, M., Riedinger, V., Rollin, O., Rundlöf, M., Sardinas, H. S., Scheper, J., Sciligo, A.R., Smith, H.G., Steffan-Dewenter, I., Thorp, R., Tscharntke, T., Verhulst, J., Viana, B.F., Vaissière, B.E., Veldtman, R., Westphal, C. \& Potts, S.G. (2015) Delivery of crop pollination services is an insufficient argument for wild pollinator conservation. Nature Communications, 6, 7414.

Klein, A.M., Vaissière, B.E., Cane, J.H., Steffan-Dewenter, I., Cunningham, S.A., Kremen, C., Tscharntke, T. (2007) Importance of pollinators in changing landscapes for world crops. Proceedings. Biological sciences / The Royal Society, 274, 303-13.

Klein, A.M., Brittain, C., Hendrix, S.D., Thorp, R., Williams, N., Kremen, C. (2012) Wild pollination services to California almond rely on semi-natural habitat. Journal of Applied Ecology, 49, 723-732.

Kuhlmann, M., Guo, D., Veldtman, R., Donaldson, J. (2012) Consequences of warming up a hotspot: species range shifts within a centre of bee diversity. Diversity and Distributions, 18, 885-897.

Latorraca, A., Marques, G.J.G., Sousa, K.V., Fornes, N.S. (2008) Agrotóxicos utilizados na produção de tomate em Goiânia e Goianápolis e efeitos na saúde humana. Comunicação em Ciências da Saúde, 19, 365-374. 
Leadley, P., Pereira, H.M., Alkemade, R., Fernandez-Manjarres, J.F., Proenca, V., Scharlemann, J.P.W., Walpole, M.J. (2010) Biodiversity Scenarios: Projections of 21st Century Change in Biodiversity and Associated Ecosystem Services. Technical Series No. 50. Secretariat of the Convention on Biological Diversity (CBD). Montreal, Canada, 132 p.

Lima, S.C. (1996) As veredas do Ribeirão Panga no Triângulo Mineiro e a evolução da paisagem. São Paulo, USP, Tese, Doutorado em Geografia Física, 260 p.

MacArthur, R. H., Wilson, E. O. (1967) The theory of island biogeography. Princeton University Press, Princeton, 203 p.

Machado A.B.M.; Brescovit, A.D.; Mielke, O.H.; Casagrande, M.; Silveira, F.A.; Ohwe, F.P.; Zepellini, D.; De Maria, M. (2008) Panorama geral dos invertebrados terrestres ameaçados de extinção no Brasil. In: Machado, A. B. M.; Drummond, G. M. \& Paglia, A. P. (orgs.) Livro Vermelho da Fauna Brasileira Ameaçada de Extinção. Vol. 1. Brasília, Ministério do Meio Ambiente e Recursos Naturais Renováveis, 316 p.

McGregor, S.E. (1976) Insect pollination of cultivated crop plants. Agricultural Research Service, United States Department of Agriculture, Washington, D.C.

McNeely, J., Scherr, S. (2003) Ecoagriculture: strategies to feed the world and save wild biodiversity. Island Pr.

Melo-Silva, C., Gomes, F.L., Gonçalves, B.B., Bergamini, L.L., Bergamini, B.A.R., Elias, M.A.S., Franceschinelli, E.V. (2013) Native bees pollinate tomato flowers and increase fruit production. Journal of Pollination Ecology, 11, 41-45.

Melo-Silva, C., Bergamini, L.L., Bergamini, B.A.R., Elias, M.A.S., Moreira, G.L., Morais, J.M., Franceschinelli, E.V. (no prelo) High species richness of native pollinators in brazilian tomato crops. Brazilian Journal of Biology. 
Memmott, J., Craze, P.G., Waser, N.M., Price, M.V. (2007) Global warming and the disruption of plant-pollinator interactions. Ecology Letters, 10, 710-717.

Millennium Ecosystem Assessment (2005) Ecosystems and Human Well-being: Biodiversity Synthesis. World Resources Institute, Washington, DC.

Ministério do Meio Ambiente (2015) Lista Oficial das Espécies da Fauna Brasileira Ameaçadas de Extinção - Instrução Normativa MMA no. 03, de 27 de maio de 2003. Brasília, DF, Brazil: Ministério do Meio Ambiente. URL http://www. mma.gov.br/biodiversidade/espécies-ameaçadas-deextinção/fauna-ameaçada. Acesso em:15 de Março de 2015.

Moss, R.H., Edmonds, J.A., Hibbard, K.A., Manning, M.R., Rose, S.K., Van Vuuren, D.P., Carter, T.R., Emori, S., Kainuma, M., Kram, T., Meehl, G.A., Mitchell, J.F.B., Nakicenovic, N., Riahi, K., Smith, S.J., Stouffer, R.J., Thomson, A.M., Weyant, J.P., Wilbanks, T.J. (2010) The next generation of scenarios for climate change research and assessment. Nature, 463, 747-756.

Myers, N., Mittermeier, R.A., Mittermeier, C.G., da Fonseca, G.A.B., Kent, J. (2000) Biodiversity hotspots for conservation priorities. Nature, 403, 853-858.

Nocelli, R.C.F., Malaspina, O., Carvalho, S.M., Lourenço, C.T., Roat, T.C., Pereira, A.M., Silva-Zacarin, E.C.M. (2012) Abelhas e os defensivos agrícolas. In: Imperatriz-Fonseca, V.L., Canhos, D., Alves, D.A., Saraiva, A.M. (org) Polinizadores no Brasil: contribuição e perspectivas para biodiversidade, uso sustentável, conservação e serviços ambientais. São Paulo, EDUSP, 285-300 p.

Nunes-Silva, P., Hrncir, M., Imperatriz-Fonseca, V.L. (2010) A polinização por vibração. Oecologia Australis, 14, 140-151.

Oliveira, D. G. R. de. (2015) Primatas do cerrado: conservação, biogeografia e mudanças climáticas. Brasília, UNB, Tese, Doutorado em Ecologia, 242 p. 
Ollerton, J., Winfree, R., Tarrant, S. (2011b) How many flowering plants are pollinated by animals? Oikos, 120, 321-326.

Parmesan, C.,Yohe, G. (2003). A globally coherent fingerprint of climate change impacts across natural systems. Nature, 421, 37-42.

Parmesan, C. (2006). Ecological and evolutionary responses to recent climate change. Annual Review of Ecology Evolution and Systematics, 37, 637-669.

Peterson, A.T. (2001) Predicting species geographic distributions based on ecological niche modeling. Condor,103, 599-605.

Peterson A.T., Soberón, J., Pearson, R.G., Anderson, R., Martínez-Meyer, E., Nakamura, M., Araújo, M. (2011) Ecological Niches and Geographic Distributions. Princeton: Princeton University Press, 328 p.

Polce, C., Garratt, M.P., Termansen, M., Ramirez-Villegas, J., Challinor, A.J., Lappage, M.G., Boatman, N.D., Crowe, A., Endalew, A.M., Potts, S.G., Somerwill, K.E., Biesmeijer, J.C. (2014) Climate-driven spatial mismatches between British orchards and their pollinators: Increased risks of pollination deficits. Global Change Biology, 20, 2815-2828.

Potts, S., Biesmeijer, K., Bommarco, R., Breeze, T., Carvalheiro, L., Franzén, M., González-Varo, J.P., Holzschuh, A., Kleijn, D., Klein, A.M., Kunin, B., Lecocq, T., Lundin, O., Michez, D., Neumann, P., Nieto, A., Penev, L., Rasmont, P., Ratamäki, O., Riedinger, V., Roberts, S., Rundlöf, M., Scheper, J., Sørensen, P., Steffan-Dewenter, I., Stoev, P., Vilà, M., Schweiger, O. (2015) Status and Trends of European Pollinators. Pensoft Publishers, Sofia, Bulgaria, 72 p.

Potts, S.G., Biesmeijer, J.C., Kremen, C., Neumann, P., Schweiger, O., Kunin, W.E. (2010) Global pollinator declines: trends, impacts and drivers. Trends in Ecology \& Evolution, 25, 345-53. 
Qiao, H., Sóberon, J., Peterson, T.A. (2015) No silver bullets in correlative ecological niche modeling: Insights from testing among many potential algorithms for niche estimation. Methods in Ecology and Evolution, 6, 1126-1136.

Rader, R., Reilly, J., Bartomeus, I., Winfree, R. (2013) Native bees buffer the negative impact of climate warming on honey bee pollination of watermelon crops. Global Change Biology, 19, 3103-3110.

Rambaldi, D.M.; Oliveira, D.A.S. (2003) Fragmentação de ecossistemas: causas, efeitos sobre a Biodiversidade e recomendações de políticas públicas. MMA/SBF, Brasília, 510 p.

Reis-Filho, J.S., Marin, O.B., Fernandes, P.M. (2009) Os agrotóxicos na produção de tomate de mesa na região de Goianápolis, Goiás. 2009, 307-316. Pesquisa Agropecuária Tropical, 39, 307-316.

Ricketts, T.H., Regetz, J., Steffan-Dewenter, I., Cunningham, S. A., Kremen, C., Bogdanski, A., Gemmill-Herren, B., Greenleaf, S. S., Klein, A. M., Mayfield, M. M., Morandin, L. A., Ochieng, A., Potts, S.G., Viana, B.F.(2008) Landscape effects on crop pollination services: are there general patterns? Ecology Letters, 11, 499-515.

Root, T.L., Price, J.T, Hall, K.R., Schneider, S.H., Rosenzweig, C., Pounds, J.A. (2003) Fingerprints of global warming on wild animals and plants. Nature, 421, 57-60. Roubik, D. (1995) Pollination of cultivated plants in the tropics. FAO agricultural Services Bulletin, 118, Rome, Food and Agriculture Organization of the United Nations, 198 p. 
Rueda, M., Hawkins, B.A., Morales-Castilha, I., Vidanes, R.M., Ferrero, M. \& Rodríguez, M. Á. (2013) Does fragmentation increase extinction thresholds? A European-wide test with seven forest birds. Global Ecology and Biogeography, 22, 1282-1292.

Santos, S. B., Roselino, A. C., Hrncir, M., \& Bego, L. R. (2009) Pollination of tomatoes by the stingless bee Melipona quadrifasciata and the honey bee Apis mellifera (Hymenoptera, Apidae). Genetics and molecular Research, 8, 751-757.

Schmid-Hempel, R., Eckhardt, M., Goulson, D., Heinzmann, D., Lange, C., Plischuk, S., et al. (2014) The invasion of southern South America by imported bumblebees and associated parasites. Journal of Animal Ecology, 83, 823-837.

Schmuck, R., Schoning, R., Stork, A., Schramel, O. (2001) Risk posed to honeybees (Apis melifera L., Hymenoptera) by an imidacloprid seed dressing of sunflowers. Pest Management Science, 57, 225-238.

Schneider, C.W., Tautz, J., Grünewald, B., Fuchs, S. (2012) RFID tracking of sublethal effects of two neonicotinoid inseticides on the foranging behavior of Apis mellifera. Plos One, 7, e30023.

Silva, J. da. (2007) O uso do ensaio cometa para ensino de genética toxicológica. Sociedade Brasileira de Genética, 2, 30-33.

Shaffer, M. L. (1981) Minimum population sizes for species conservation. Bioscience, 31, 131-134.

Skerl, M.I.S., Gregorc, A. (2010) Heat shock proteins and cell death in situ localization in hypopharyngeal glands of honeybee (Apis mellifera carnica) workers after imidacloprid or coumaphos treatment. Apidologie, 41, 73-86.

Soberón, J. (2007) Grinnellian and Eltonian niches and geographic distributions of species. Ecology Letters, 10, 1115-1123. 
Soderlund, D.M., Clark, J.M., Sheets, L.P., Mullin, L.S., Piccirillo, V.J., Sargent, D., Stevens, J.T., Weiner, M.L (2002) Mechanisms of pyrethroid neurotoxicity: implications for cumulative risk assessment. Toxicology, 171, 3-59.

Sparks, T.H., Yates, T.J. (1997) The effect of spring temperature on the appearance dates of British butterflies 1883-1993. Ecography, 20, 368-374.

Steffan-Dewenter, I., Potts, S.G., Packer, L. (2005) Pollinator diversity and crop pollination services are at risk. Trends in Ecology \& Evolution, 20, 651-652.

Stone, G.N. (1994) Activity patterns of females of the solitary bee Anthophora plumipes in relation to temperature, nectar supplies and body size. Ecological Entomology, 19,177-189.

Tennekes, H.A. (2010) The significance of the Druckrey-Kupfmuller equation for risk assessment - the toxicity of neonicotinoid insecticides to arthropods is reinforced by exposure time. Toxicology, 276, 1-4.

Thompson, H.M. (2002) Behavioral effects of pesticides in bees - their potential for use in risk assessment. Ecotoxicology, 12, 317-330.

Thuiller, W., Lavorel, S., Araujo, M.B. (2005) Niche properties and geographical extent as predictors of species sensitivity to climate change. Global Ecology and Biogeography, 14, 347-357.

Tice, R.R., Agurell, E., Anderson, D., Burlinson, B., Hartmann, A., Kobayashi, H., Miyamae, Y., Rojas, E., Ryu, J.C., Sasaki, Y. F. (2000) Single cell gel/comet assay: Guidelines for in vitro and in vivo genetic toxicology testing. Environmental Molecular Mutagenesis, 35, 206-221.

Tscharntke, T., Steffan-Dewenter, I., Kruess, A., Thies, C. (2002a) Characteristics of insect populations on habitat fragments: A mini review. Ecological Research, 17, 229-239. 
Tscharntke, T., Steffan-Dewenter, I., Kruess, A., Thies, C. (2002b) Contribution of small habitat fragments to conservation of insect communities of grasslandcropland landscapes. Ecological Applications, 12, 354-363.

Tscharntke, T., Tylianakis, J.M., Rand, T.A., Didham, R.K., Fahrig, L., Batáry, P., Bengtsson, J., Clough, Y., Crist, T.O., Dormann, C.F., Ewers, R.M., Fründ, J., Holt, R.D., Holzschuh, A., Klein, A.M., Kleijn, D., Kremen, C., Landis, D.A., Laurance, W., Lindenmayer, D., Scherber, C., Sodhi, N., Steffan-Dewenter, I., Thies, C., van der Putten, W.H., Westphal, C. (2012) Landscape moderation of biodiversity patterns and processes - eight hypotheses. Biological Reviews, 87, $661-685$.

Vandame, R., Meled, M., Colin, M.E., Belzunces, L.P. (1995). Alteration of the homing-flight in the honey bee Apis mellifera L. exposed to sublethal dose of Deltamethrin. Environmental Toxicology Chemistry, 14, 855-860.

Vanengelsdorp, D., Hayes, J., Underwood, R.M., Pettis, J. (2008) A Survey of honey bee colony losses in the US, Fall 2007 to Spring 2008. PLoS ONE, 3, e4071.

Viana, B.F., Boscolo, D., Neto, E.M., Lopes, L.E., Lopes, A.V., Ferreira, P.A., Pigozzo, C.M., Primo, L.M. (2012) How well do we understand landscape effects on pollinators and pollination services. Journal of Pollination Ecology, 7, 31-41.

Visser, M.E., Both, C. (2005) Shifts in phenology due to global climate change: the need for a yardstick. Proceedings of the Royal Society B, 272, 2561- 2561.

Walther, G., Post, E., Convey, P., Menzel, A., Parmesan, C., Beebee, T. J. C., Fromentin, J.M, Guldberg, O. H., Bairlein, F. (2002) Ecological responses to recent climate change.Nature, 416, 389-395.

Weisburger, J. H. (1999) Carcinogenicity and mutagenicity testing, then and now. Mutation Research, Reviews in Mutation Research, 437, 105-112. 
Williams, I. (1994) The dependence of crop production within the European Union on pollination by honey bees. Agricultural Zoology Reviews, 6, 229-257.

Willmer, P.G., Unwin, D.M. (1981) Field analyses of insect heat budgets: reflectance, size and heating rates. Oecologia, 50, 250-255.

Willmer, P.G., Stone, G.N. (2004) Behavioral, ecological, and physiological determinants of the activity patterns of bees. Advances in the Study of Behavior, 34, 347-466.

Willmer, P. (2011) Pollination and floral ecology. Princeton University Press, Princeton, $778 \mathrm{p}$.

Winfree, R., Kremen, C. (2009) Are ecosystem services stabilized by differences among species? A test using crop pollination. Proceedings of the Royal Society B, 276, $229-237$. 
Capítulo I

Influência do contexto da paisagem na abundância de abelhas nativas em cultivos de tomate 


\section{Resumo}

Há evidências do declínio da abundância de polinizadores e consequentemente os seus serviços em algumas regiões do mundo, com possíveis impactos negativos para o funcionamento dos ecossistemas. A resposta específica das abelhas à mudança antropogênica na escala da paisagem ainda é pouco compreendida, em parte porque os polinizadores podem atuar ou responder em diferentes escalas espaciais. O objetivo deste estudo foi testar a influência do contexto da paisagem na abundância de abelhas polinizadoras em cultivos de tomate. As paisagens no entorno das plantações foram classificadas a partir de imagem de satélite e as variáveis preditoras proporção de vegetação nativa (Prop), o tamanho relativo do maior fragmento (rLPS) e a distância entre o cultivo e a vegetação nativa mais próxima foram calculados. A abundância de abelhas nativas foi amostrada em plantios de tomateiro cultivados no sistema convencional estaqueado em campo aberto na região do Cerrado entre 2010 e 2011. As espécies foram divididas em cinco grupos de acordo com a semelhança morfológica e ecológica. Os resultados deste estudo mostram que o contexto de paisagem influenciou a abundância dos cinco grupos de polinizadores de tomate. Abelhas de menor tamanho corporal, como as espécies do grupo Exomalopsis responderam em escalas menores enquanto as abelhas de tamanho corporal maior, tais como as dos grupos Centris $e$ Bombus/Eulaema responderam em escalas maiores. A abundância de todos os polinizadores juntos (Buzzers), do grupo Exomalopsis e Centris está associada com um aumento da proporção de vegetação nativa. A maioria dos grupos apresentou maior abundância em paisagens mais fragmentadas. Não houve relação entre a distância dos fragmentos de vegetação nativa e a abundância para nenhum dos grupos. O presente estudo mostra a importância de se considerar, além da perda de habitat, os efeitos da fragmentação sobre a biodiversidade e os serviços ecossistêmicos que essa 
biodiversidade provê e reforça a necessidade de estudos em múltiplas escalas para detectar a importância do contexto da paisagem na assembleia de polinizadores locais.

Palavras-chave: Vegetação nativa, fragmentação, perda de habitat, conservação, polinizadores.

Influence of landscape context on the abundance of native bee pollinators in tomato crops in Central Brazil

\begin{abstract}
Evidences show that pollinator abundance has declined and, consequently, also has their services in some regions of the world, with possible negative impacts on ecosystem functioning. The specific response of bees to anthropogenic changes at the landscape scale remains poorly understood, partly because pollinators may respond at different spatial scales. The goal of this study was to evaluate the influence of landscape context at multiple spatial scales on the abundance of bee pollinators in tomato crops. The landscapes surrounding the crops were classified from satellite image and the predictor variables proportion of native vegetation (Prop), relative size of the largest fragment (rlps) and the distance between the crop and the closest native vegetation were calculated. Their abundance was obtained from tomato crops grown in a conventional system in the Cerrado region in 2010 and 2011. Only buzzers were analyzed. The species were categorized into five groups according to taxonomical and ecological relationships. The results of this study showed that the landscape context influenced the abundance of the five groups of tomato pollinators. Bees with a smaller body size, such as species of the Exomalopsis group, responded at smaller scales, while bees with a
\end{abstract}


larger body size, such as the Centris and Bombus/Eulaema groups responded at larger scales. The abundance of all pollinators and of the Exomalopsis and Centris groups increased with native vegetation cover. Most groups showed higher abundances in more fragmented landscapes. The results of the present work reinforce the need for maintaining natural habitats around crop areas, even if fragmented, for the conservation of tomato pollinator assemblage.

Key-words: Buzzers, Cerrado, ecosystem service, Exomalopsis, fragmentation, habitat loss, Halictidae.

\section{Introdução}

O declínio das populações de insetos polinizadores, principalmente abelhas, reportado em diferentes partes do mundo (Potts et al. 2010; Goulson et al. 2015; Potts et al. 2015) é preocupante devido a sua importância na polinização de $78 \%$ das angiospermas nas regiões temperadas e 94\% nas regiões tropicais (Ollerton et al. 2011). Portanto, o declínio populacional de abelhas poderia causar alterações no funcionamento e diversidade dos ecossistemas naturais (Allen-Wardell et al. 1998). Além disso, abelhas são importantes para muitas plantas cultivadas (Klein et al. 2007; Melo-Silva et al. 2013), e vários estudos já demonstram haver relação entre perda de polinizadores e redução da produtividade dos cultivos (Kevan 1977; Ricketts et al. 2004).

O declínio das populações de abelhas pode estar relacionado à combinação de diferentes fatores como o uso de pesticidas (Whitehorn et al. 2012), a ocorrência de doenças e parasitas (Fürst et al. 2014), além da perda e fragmentação do habitat (Kearns et al. 1998). Para as comunidades de insetos polinizadores, que incluem abelhas, vespas, 
moscas, besouros, borboletas e mariposas, a perda e fragmentação de habitat provavelmente representam os impactos mais importantes (Kruess \& Tscharntke 1994; Steffan-Dewenter et al. 2002; Steffan-dewenter 2003; Steffan-Dewenter \& Kuhn 2003). Os possíveis efeitos negativos da perda de habitat sobre esse grupo incluem a redução na disponibilidade de recursos alimentares e a falta de sítios de nidificação, levando a menores tamanhos populacionais e consequentemente à perda de espécies. Diferentes métricas do nível de conservação da paisagem têm mostrado efeitos positivos sobre a riqueza de espécies e a abundância de abelhas e consequentemente sobre a polinização de plantas cultivadas (Viana et al. 2012), como por exemplo, a proximidade de fragmentos de vegetação nativa (Ricketts et al. 2008), a proporção de vegetação nativa (Steffan-Dewenter et al. 2002) e o tamanho do fragmento (Aizen \& Feinsinger 1994).

Tais efeitos e a escala em que atuam, entretanto, são altamente dependentes das características de cada espécie de abelha (Greenleaf \& Kremen 2006). Respostas de espécies de abelhas às mudanças antropogênicas na escala da paisagem continuam mal compreendidas. Em parte, porque os táxons de abelhas apresentam uma variação considerável em aspectos da sua história de vida (Michener 2001), como por exemplo, o grau de especialização no recurso floral, o nível de sociabilidade e o tipo de local que utilizam para nidificação (Goulson et al. 2005; Morandin et al. 2007; Ricketts et al. 2008). Acrescida às diferenças na capacidade de dispersão (Greenleaf et al. 2007), essa variação leva a diferentes respostas frente às propriedades da paisagem (Winfree \& Kremen 2009). Portanto, as alterações nas características da paisagem em diferentes escalas podem impactar os serviços ecossistêmicos através dos efeitos sobre a abundância dos polinizadores.

Neste trabalho analisamos a abundância de diferentes grupos de espécies de abelhas em resposta às características da paisagem, usando como sistema de estudo as 
abelhas nativas presentes em plantações de tomate convencional (Solanum lycopersicum). Entre as espécies de abelhas observadas até então em plantações de tomate no Brasil (Nunes-Silva et al. 2010) apenas espécies nativas realizam polinização por vibração (Franceschinelli, E. V., com. pess.).

O objetivo deste estudo foi testar a influência das características da paisagem na abundância de abelhas nativas polinizadoras do tomateiro. Nesse trabalho buscamos responder as seguintes questões: (1) Quais são os efeitos da proporção de vegetação nativa e do seu grau de fragmentação sobre a abundância de diferentes grupos de abelhas, e em quais escalas esses efeitos são mais evidentes? (2) Plantações mais próximas dos remanescentes de vegetação natural apresentam maior abundância de abelhas? (3) Existem diferenças nas respostas de diferentes grupos de espécies de abelhas?

\section{Métodos}

\section{Local e período das coletas}

O presente estudo foi realizado, no estado de Goiás, em 10 plantações de tomate convencional estaqueado em campo aberto no ano de 2010 (entre 7 de Agosto e 17 de Outubro) e 14 plantações de tomate convencional estaqueado em campo aberto no ano de 2011 (entre 21 de Maio e 27 de Setembro) (Figura 1). Nesses municípios ocorrem fragmentos de mata e cerrado inseridos em uma matriz composta principalmente por pastagem e áreas agricultáveis, nas quais se cultivam tomate, pepino, repolho, milho, feijão, laranja. No sistema em estudo, os remanescentes naturais constituem pequenas manchas de formato irregular e frequentemente formam estreitos corredores de vegetação junto aos corpos d'água. 


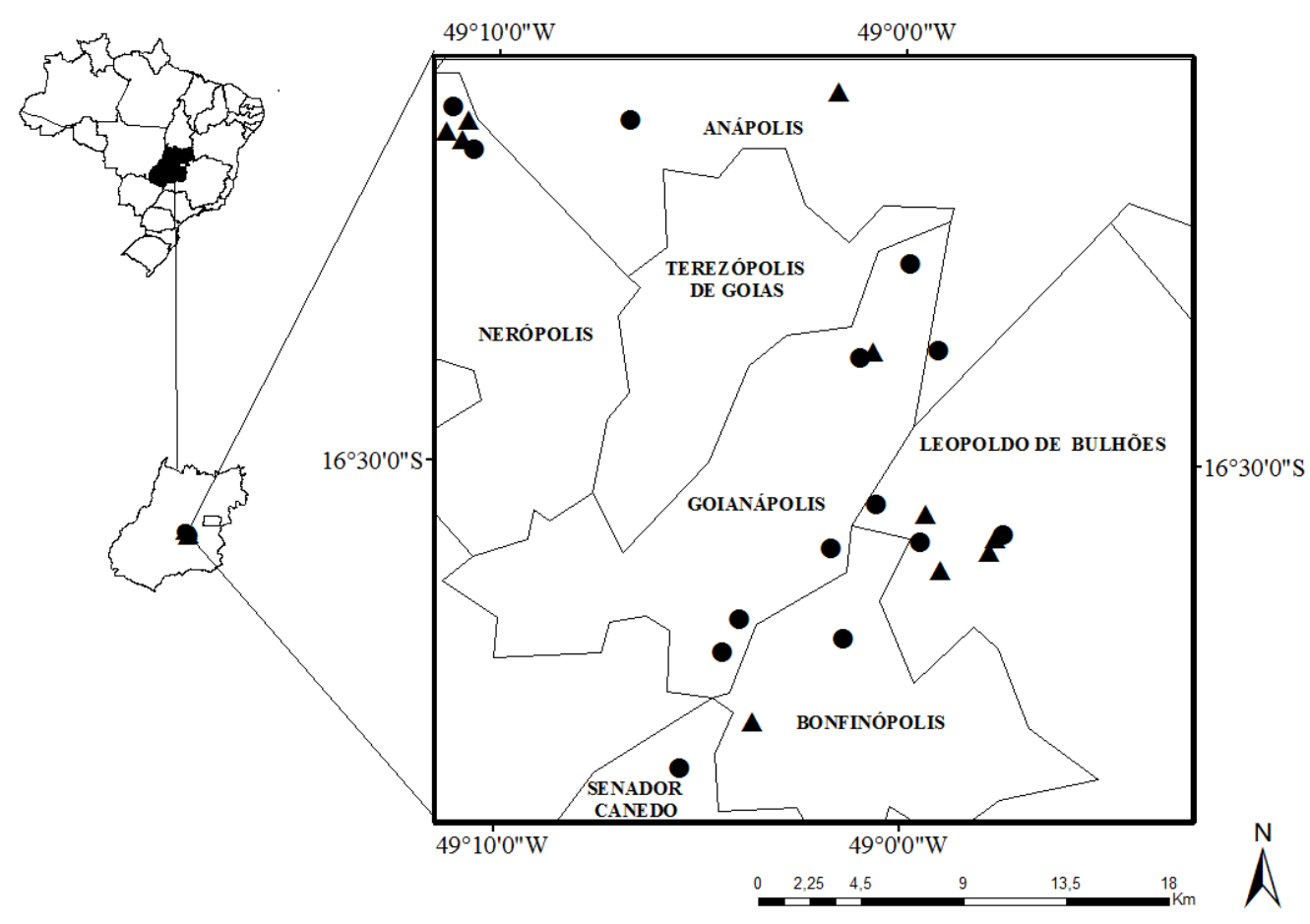

Figura 1. Localização de 10 cultivos de tomate convencional estaqueado em campo aberto em 2010 e de 14 cultivos em 2011. Triângulos preenchidos correspondem ao ano de 2010 e círculos preenchidos correspondem ao ano de 2011.

As paisagens no entorno das plantações foram classificadas a partir de uma imagem de satélite Landsat5-TM (datada de 10 de outubro de 2005), com resolução espacial de $30 \times 30 \mathrm{~m}$, georreferenciada com base nas cartas topográficas do Instituto Brasileiro de Geografia e Estatística - IBGE, na escala de 1:50.000. As coordenadas foram adquiridas no sistema UTM, Datum SAD 1984 e as bandas espectrais utilizadas foram TM3, TM4 e TM5. Os fragmentos de vegetação nativa (cerrado e matas nativas) foram delimitados através de classificação manual. Círculos (buffers) de 0,75, 1,0, 1,5, 2,0 e 3,0 quilômetros $(\mathrm{Km})$ de raio tomando como centro cada ponto amostral (cultivo de tomate) foram delimitados usando as imagens classificadas pelo método descrito acima (Figura 2). Círculos (buffers) com raios menores que $0,5 \mathrm{Km}$ frequentemente não 
continham vegetação nativa, por isso os círculos foram delimitados a partir de $0,75 \mathrm{Km}$.

Os procedimentos de georreferenciamento e classificação foram realizados no sistema de processamento de imagens de sensoriamento remoto ArcGIS 9,3 (Esri Inc.).

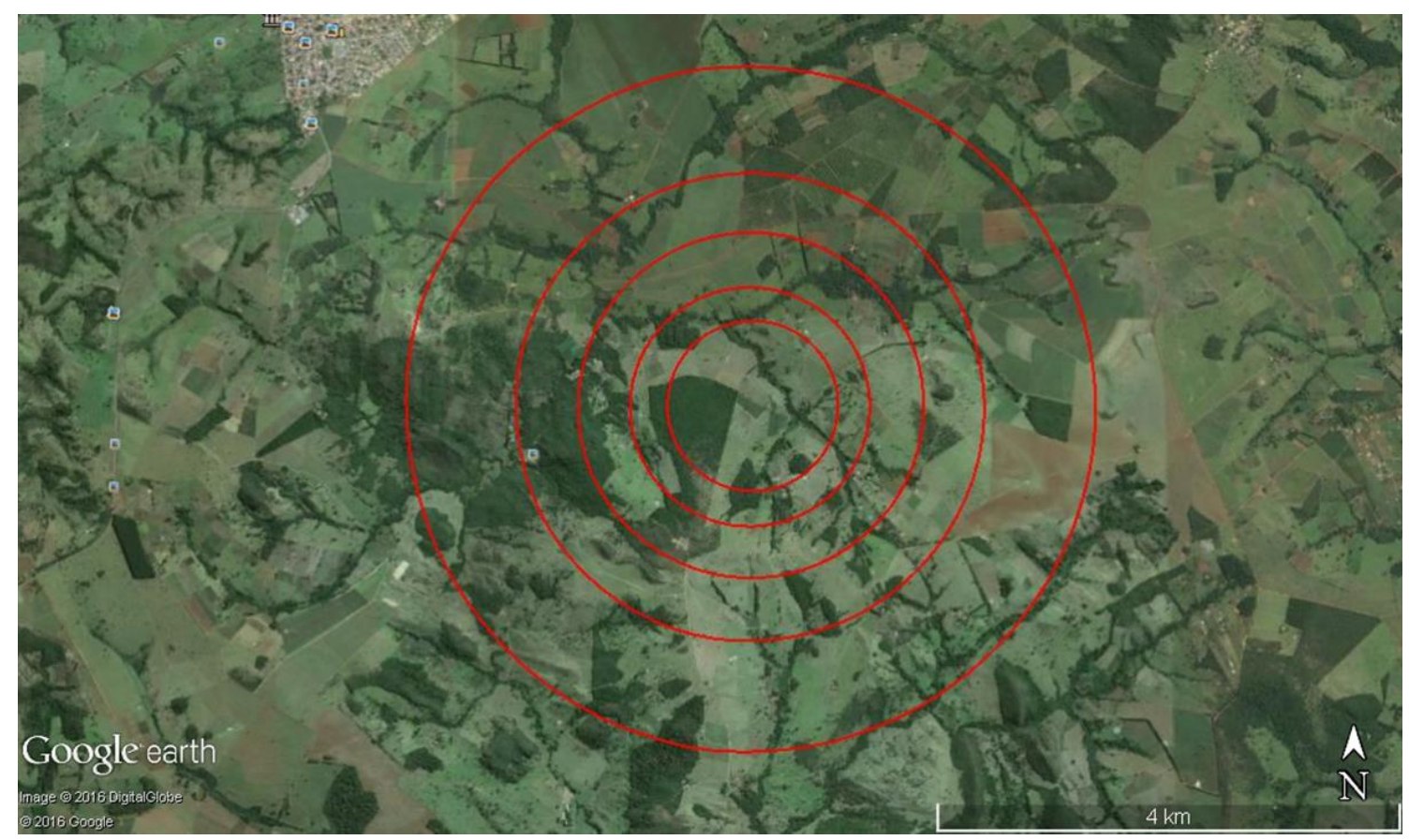

Figura 2. Cultivo de tomate ao centro e os cinco círculos de $0,75,1,0,1,5,2,0$ e 3,0 km de raio delimitados para o cálculo da vegetação e do tamanho relativo do maior fragmento (RLPs).

Dois valores foram calculados dentro da área delimitada para cada um dos cinco buffers: 1) proporção de vegetação nativa na paisagem (Prop) dentro de cada círculo; e 2) o tamanho relativo do maior fragmento (rLPS) (Bascompte \& Sole 1996; Montoya et al. 2010), que é uma medida de continuidade da vegetação e varia entre 0 e 1 . Os valores do rLPS perto de 1 indicam paisagens com pouca fragmentação da vegetação nativa. Ao contrário de índices como o número de manchas e o tamanho médio do fragmento que são altamente correlacionados com a quantidade de habitat (Fahrig 
2003), o índice rLPS permite uma medida mais direta do grau de fragmentação (Bascompte \& Sole 1996). Valores combinados de Prop e rLPS abaixo de 0,25 indicam paisagens com forte perturbação humana e uma elevada fragmentação da vegetação nativa, enquanto que valores acima de 0,75 caracterizam paisagens com vegetação nativa preservada e ligeiramente fragmentada (adaptado de Montoya et al. 2010). Além dessas duas medidas, a distância em metros entre cada cultivo de tomate e o fragmento mais próximo de vegetação nativa maior que 1 hectare foi calculado. Os valores destas variáveis foram calculados utilizando o software R (R Development Core Team, 2015) usando os pacotes MapTools (Bivand \& Lewin-Koh, 2015), rgdal (Bivand et al. 2015) e raster (Hijmans 2015).

\section{Descrição da planta}

O tomateiro é uma planta da família Solanaceae, espécie Solanum lycopersicum. As flores, hermafroditas, costumam ocorrer na quantidade de 3 a 12, reunidas em forma de monocásios, são pequenas e amarelas (Fontes \& Silva 2002). Os estames formam um tubo em torno do pistilo e as anteras possuem deiscência poricida, as quais precisam ser vibradas para que o pólen seja liberado (Buchmann 1983). Embora a polinização espontânea possa acontecer, pois essa espécie possui sistema reprodutivo autocompatível, é altamente dependente de fatores climáticos, entre eles o vento. Portanto, uma maior eficiência no processo de polinização é conseguida quando abelhas vibram as flores e as anteras, melhorando a qualidade e quantidade de frutos e sementes (McGregor 1976; Melo-Silva et al. 2013; Deprá et al. 2014). Os principais cultivares de tomateiro nos cultivos estudadas foram 'Italiano' e 'Dominador'. 


\section{Frequência de visitas}

As atividades das abelhas foram registradas em cada cultivo entre as fileiras de tomateiro no centro dos cultivos por dois observadores a fim de estimar a abundância de abelhas. As observações foram realizadas das $9 \mathrm{~h} 00$ as $13 \mathrm{~h} 00$ horas, em pelo menos dois dias diferentes, sem nuvens ou com poucas nuvens e a velocidade do vento inferior a 3 m/s. A abundância das abelhas foi medida através da inspeção das visitas de abelhas às flores do tomateiro em dois transectos contíguos de 100 metros cada localizados entre as fileiras de tomateiro no centro dos cultivos. As observações das visitas de abelhas às flores do tomateiro foram realizadas a cada 15 minutos (intervalo de cinco minutos) do lado direito e esquerdo de cada transecto, totalizando 360 minutos em cada cultivo em 2010 e entre 80 e 160 minutos em cada cultivo em 2011. A abundância de visitas às flores foi estimada somando todas as visitas durante o tempo total de coleta em cada ano para cada grupo.

Visitantes florais foram observados durante cada visita para verificar se o pólen foi coletado por vibração das anteras. Dado o papel das abelhas para aumentar as taxas de polinização, observações foram feitas para reconhecer os polinizadores efetivos (polinização por vibração) e distingui-los dos visitantes florais pilhadores que roubam pólen inserindo suas mandíbulas dentro das anteras.

Apenas espécies de abelhas observadas que coletaram pólen por vibração das anteras foram selecionadas para o estudo e agrupadas com base na similaridade ecológica, sendo categorizadas em cinco grupos, conforme descrito na Tabela 1. 
Tabela 1. Critérios para agrupamento de espécies de abelhas nativas observadas nos cultivos de tomate convencional estaqueado em campo aberto com base na similaridade morfo-ecológica.
Grupo
Critério

1.Buzzers $=$ Exomalopsis,

Halictidae, Centris, capazes de realizar a polinização por vibração, vibram as Bombus/Eulaema.

2. Exomalopsis

3. Halictidae

4. Centris

\section{Bombus/Eulaema}

anteras para retirar grãos de pólen. Todos os grupos descritos abaixo formaram esse grupo.

Devido as semelhanças comportamentais e morfológicas entre espécies desse gênero, são abelhas de pequeno porte, tamanho corporal de aproximadamente $0,8 \mathrm{~cm}$.
Abelhas da família Halictidae, com a exceção do gênero Dialictus (que não realizou polinização por vibração), também são muito semelhantes, coloração metálica verde, tamanho corporal de aproximadamente $1,0 \mathrm{~cm}$.
Abelhas do gênero Centris são morfologicamente distintas de outras abelhas que visitam as flores do tomateiro, tamanho corporal de aproximadamente $1,4 \mathrm{~cm}$.

Abelhas dos gêneros Bombus e Eulaema possuem tamanho do corpo similar (aproximadamente 1,8 cm) e algumas espécies são morfologicamente semelhantes e de coloração preta. 


\section{Análises estatísticas}

Para testar se a abundância de abelhas é maior em paisagens mais preservadas (ou seja, paisagens com uma maior proporção de vegetação nativa e valores maiores do índice rLPS) foi utilizada a abordagem de seleção de modelos. Para cada grupo de espécies de abelhas e a escala da paisagem (raios) modelos lineares generalizados (GLM) de Poisson foram ajustados, tendo a abundância de abelhas como variável resposta e a proporção de vegetação nativa, rLPS ou a combinação de ambos como variáveis preditoras. Além desses modelos, um modelo com apenas o intercepto também foi ajustado. No total, 16 modelos foram ajustados para cada grupo nas cinco escalas da paisagem utilizadas nesse estudo.

Devido à dificuldade de convergência dos modelos quando o ano foi incluído como efeito aleatório, os dados dos dois anos foram analisados separadamente. Os tempos de observação em cada cultivo foram diferentes em 2011, por isso essa variável foi controlada nos modelos de 2011.

Os modelos ajustados foram, então, classificados de acordo com o AICc, critério de informação de Akaike corrigido (Burnham \& Anderson 2002), e os pesos de Akaike foram calculados para cada modelo. A inferência dos modelos foi feita através dos intervalos de confiança para os coeficientes médios calculados entre os melhores modelo(s) $(\Delta$ AICc $<2)$. A fim de avaliar o ajuste do modelo, uma medida de pseudo $\mathrm{R}^{2}$ seguindo a formulação de Heinzl \& Mittlböck (2003) foi calculada, juntamente com um teste qui-quadrado da razão de verossimilhança.

Para testar se há relação entre a distância dos fragmentos de vegetação nativa e a abundância de abelhas em cada grupo foram utilizados os modelos lineares generalizados mistos (GLMM), tendo a abundância de abelhas como variável resposta e a distância como variável preditora. Nesses modelos a abundância foi calculada como o 
número de abelhas observadas por minuto e o ano foi incluído como um efeito aleatório. Usamos modelos de inclinações aleatórias para estimar a variação entre os anos nos efeitos da distância sobre a abundância de abelhas registradas nas flores do tomateiro nos 24 cultivos, 10 em 2010 e 14 em 2011.

Todas as análises foram realizadas no programa R ( $\mathrm{R}$ Development Core Team, 2015) usando os pacotes Mumin (Bartoń 2015) e lme4 (Bates et al. 2015).

\section{Resultados}

A análise das paisagens ao redor dos cultivos de tomateiros amostrados revela uma ampla variação na proporção de vegetação nativa $(0,03$ a 0,55$)$ e no $\operatorname{rLPS}(0,11$ a 1,00) nas diferentes escalas (buffers) permitindo um contraste adequado para a modelagem proposta. No entanto, esses dados caracterizam a região estudada como altamente perturbada pela atividade agrícola e vegetação nativa fragmentada, sendo que os baixos valores de rLPS ocorrem principalmente nas escalas maiores (Tabela 2). 
Tabela 2. Valores médios, mínimo e máximo de proporção de vegetação nativa (Prop) e do tamanho relativo do maior fragmento (rLPS) para cinco círculos (buffers) de diferentes raios no entorno de 10 cultivos de tomate convencional estaqueado em campo aberto no estado de Goiás em 2010 e de 14 cultivos em 2011.

\begin{tabular}{llcc}
\hline Raio & Variável & Média $(\mathbf{m i n}-\mathbf{m a x}) \mathbf{2 0 1 0}$ & Média $(\mathbf{m i n}-\mathbf{m a x}) \mathbf{2 0 1 1}$ \\
\hline $0,75 \mathrm{Km}$ & Prop & $0,25(0,12-0,55)$ & $0,18(0,04-0,38)$ \\
$1,0 \mathrm{Km}$ & Prop & $0,24(0,13-0,41)$ & $0,19(0,03-0,34)$ \\
$1,5 \mathrm{Km}$ & Prop & $0,22(0,14-0,38)$ & $0,20(0,08-0,35)$ \\
$2,0 \mathrm{Km}$ & Prop & $0,22(0,17-0,34)$ & $0,21(0,10-0,36)$ \\
$3,0 \mathrm{Km}$ & Prop & $0,24(0,18-0,32)$ & $0,24(0,13-0,32)$ \\
$0,75 \mathrm{Km}$ & rLPS & $0,61(0,30-1,00)$ & $0,68(0,41-1,00)$ \\
$1,0 \mathrm{Km}$ & rLPS & $0,54(0,22-0,98)$ & $0,61(0,37-0,91)$ \\
$1,5 \mathrm{Km}$ & rLPS & $0,41(0,22-0,70)$ & $0,47(0,15-0,84)$ \\
$2,0 \mathrm{Km}$ & rLPS & $0,32(0,16-0,50)$ & $0,41(0,22-0,69)$ \\
$3,0 \mathrm{Km}$ & rLPS & $0,30(0,11-0,64)$ & $0,38(0,13-0,74)$ \\
\hline
\end{tabular}

Um total de 656 visitas de abelhas (Buzzers) foram observadas nas flores de tomateiro, em média 0,46 \pm 0,43 (desvio padrão) visitas por minuto, durante os 3.600 minutos de observação realizados nos 10 cultivos no ano de 2010. Em 2011, das 698 visitas, foram realizadas em média $0,67 \pm 0,32$ (desvio padrão) visitas por minuto, durante os 1.660 minutos de observação realizados em 14 plantações. As espécies do gênero Exomalopsis foram as mais frequentes nos dois anos de estudo (Tabela 3). 
Tabela 3. Frequência relativa (\%) de visitas dos diferentes grupos de abelhas às flores do tomateiro em 10 cultivos de tomate convencional estaqueado em campo aberto em 2010 e 14 cultivos em 2011 no estado de Goiás. (N) corresponde a número de indivíduos.

\begin{tabular}{|c|c|c|c|c|}
\hline Grupos & $\begin{array}{c}\text { Frequência } \\
\text { de visitas }(\%) \\
\text { em } 2010 .\end{array}$ & $\begin{array}{c}\mathrm{N} \\
2010\end{array}$ & $\begin{array}{c}\text { Frequência } \\
\text { de visitas }(\%) \\
\text { em } 2011 .\end{array}$ & $\begin{array}{c}N \\
2011\end{array}$ \\
\hline Exomalopsis & 74,2 & 487 & 73,8 & 515 \\
\hline Halictidae & 10,5 & 69 & 16,6 & 116 \\
\hline Centris & 11,9 & 78 & 7,3 & 51 \\
\hline Bombus/ Eulaema & 3,4 & 22 & 2,3 & 16 \\
\hline Total & 100 & 656 & 100 & 698 \\
\hline
\end{tabular}

Entre todos os modelos relacionados com a abundância de abelhas e as variáveis da paisagem, apenas um modelo foi selecionado em cada ano para os grupos Buzzers, Exomalopsis e Centris (Tabela 4). Para o grupo Halictidae, dois modelos foram selecionados em cada ano e para o grupo Bombus/Eulaema dois modelos em 2010 e um modelo em 2011 (Tabela 4). 
Tabela 4. Descritores dos modelos selecionados para a relação entre a abundância de abelhas nativas nas flores de tomateiros e a proporção de vegetação nativa (Prop) e o tamanho relativo do maior fragmento (rLPS) para os cinco grupos de espécies de abelhas em 10 cultivos de tomate convencional estaqueado em campo aberto no ano de 2010 e em 14 cultivos de tomate no ano de 2011 no estado de Goiás. Os valores de Delta são as diferenças entre o AICc de cada modelo e o AICc do melhor modelo. Pesos de Akaike (Weigth) são estimativas normalizadas da probabilidade relativa de cada modelo e são utilizados no cálculo do modelo médio de forma que os melhores modelos têm uma maior contribuição para a estimativa dos coeficientes médios. Valores de Pseudo $\mathrm{R}^{2}$ foram calculados utilizando a formulação de Heinzl \& Mittlbock (2003). Testes qui-quadrado da razão de verossimilhança (L.ratio $\chi^{2}$ ) foram usados para testar se a diferença entre o desvio do modelo ajustado e o desvio do modelo nulo são significativas. K, o número de parâmetros do modelo; Obsv. tempo, tempo de observação.

\begin{tabular}{|c|c|c|c|c|c|c|c|c|c|}
\hline & Grupo & Modelo & $\mathbf{k}$ & AICc & Delta & Weight & $\mathbf{R}^{2}$ & L.ratio $\chi^{2}$ & $\mathbf{P}$ \\
\hline \multirow{6}{*}{ 융 } & Buzzers & Prop $2 \mathrm{Km}+$ rLPS $2 \mathrm{Km}$ & 3 & 220,4 & 0,00 & 1,000 & 0,21 & 94,17 & $<0,001$ \\
\hline & Exomalopsis & Prop $2 \mathrm{Km}+\mathrm{rLPS} 2 \mathrm{Km}$ & 3 & 200,9 & 0,00 & 1,000 & 0,32 & 120,49 & $<0,001$ \\
\hline & \multirow{2}{*}{ Halictidae } & Prop $3 \mathrm{Km}+$ rLPS $3 \mathrm{Km}$ & 3 & 86,60 & 0,00 & 0,457 & 0,19 & 25,16 & $<0,001$ \\
\hline & & Prop 3Km & 2 & 87,30 & 0,70 & 0,321 & 0,21 & 20,16 & $<0,001$ \\
\hline & Centris & Prop $3 \mathrm{Km}$ & 2 & 69,30 & 0,00 & 0,830 & 0,39 & 26,10 & $<0,001$ \\
\hline & Bombus/Eulaema & Prop 3Km & 2 & 46,50 & 0,00 & 0,359 & 0,06 & 7,54 & 0,006 \\
\hline
\end{tabular}


Tabela 4. Continuação.

\begin{tabular}{|c|c|c|c|c|c|c|c|c|c|}
\hline & Grupo & Modelo & $\mathbf{k}$ & AICc & Delta & Weight & $\mathbf{R 2}$ & L.ratio $\chi 2$ & $\mathbf{P}$ \\
\hline 용 & Bombus/Eulaema & Prop $1,5 \mathrm{Km}$ & 2 & 46,70 & 0,20 & 0,193 & 0,04 & 6,30 & 0,012 \\
\hline \multirow{6}{*}{$\overline{\bar{\nabla}}$} & Buzzers & Prop 1Km + Obsv. time & 3 & 155,3 & 0,00 & 0,766 & 0,24 & 38,02 & $<0,001$ \\
\hline & Exomalopsis & Prop $1 \mathrm{Km}+$ Obsv. time & 3 & 136,2 & 0,00 & 0,863 & 0,20 & 25,52 & $<0,001$ \\
\hline & \multirow{2}{*}{ Halictidae } & rLPS 3Km + Obsv. time & 3 & 125,8 & 0,00 & 0,707 & 0,34 & 52,57 & $<0,001$ \\
\hline & & Prop $3 \mathrm{Km}+$ rLPS $3 \mathrm{Km}+$ Obsv. time & 4 & 127,5 & 1,70 & 0,293 & 0,29 & 54,86 & $<0,001$ \\
\hline & Centris & Prop 2Km + Obsv. time & 3 & 95,80 & 0,00 & 0,770 & 0,23 & 15,86 & $<0,001$ \\
\hline & Bombus/Eulaema & rLPS $3 \mathrm{Km}+$ Obsv. time & 3 & 37,70 & 0,00 & 0,524 & 0,45 & 23,83 & $<0,001$ \\
\hline
\end{tabular}


A abundância de abelhas foi associada com as variáveis da paisagem para todos grupos nos dois anos de estudo, sendo a única exceção o grupo Bombus/Eulaema em 2010 (Figura 2). Os grupos Buzzers, Exomalopsis e Centris apresentaram uma associação positiva entre a abundância e a proporção de vegetação nativa, embora haja uma variação entre os anos no raio da proporção de vegetação nativa (Figura 2a, 2b, 2d, informação adicional está disponível em anexo, tabela S1, S2, S4). Em relação ao índice de continuidade (rLPS), houve um efeito negativo da continuidade da paisagem na abundância em 2010 apenas para os grupos Buzzers e Exomalopsis (Figura 2a, 2b), com paisagens mais fragmentadas apresentando maiores abundâncias para esses grupos.

Os resultados entre os dois anos foram conflitantes para o grupo Halictidae (Figura 2c). Em 2010, houve relação negativa entre abundância e a proporção de vegetação nativa e em 2011 houve um efeito negativo da continuidade da paisagem na abundância, com paisagens mais fragmentadas apresentando maiores abundâncias para esse grupo. Por último, para o grupo Bombus/Eulaema em 2011 houve um efeito negativo da continuidade da paisagem na abundância (Figura 2e). 


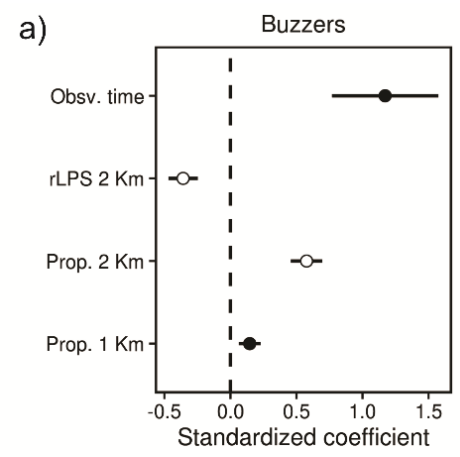

b)

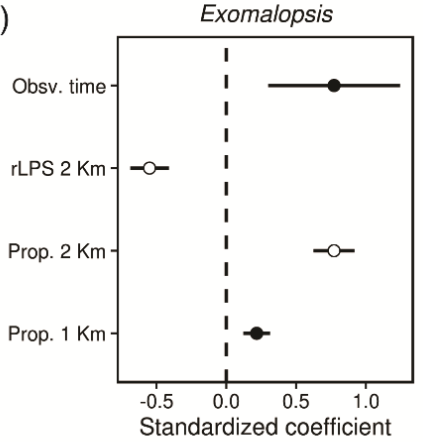

d)

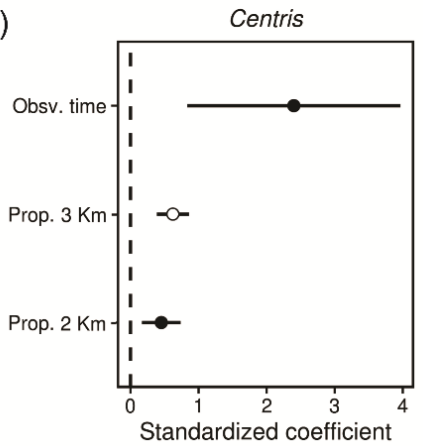

c)

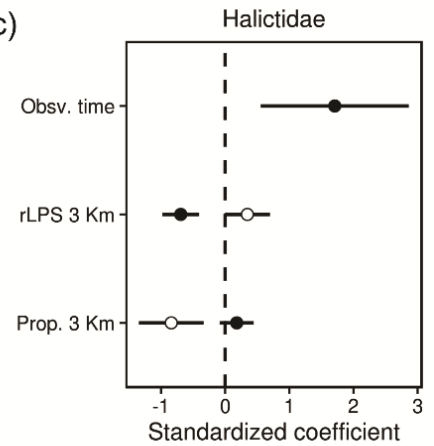

e)

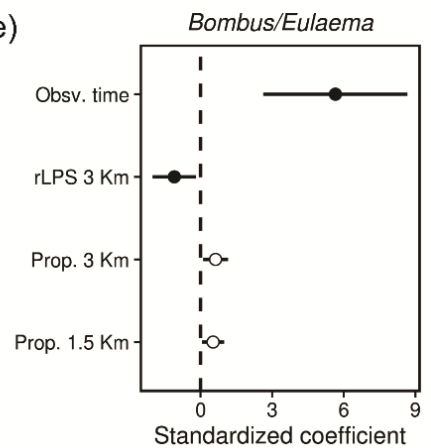

Figura 2. Coeficiente padronizado do efeito de cada variável preditora sobre a abundância de abelhas dos modelos médios para cada grupo de abelhas polinizadoras do tomateiro em cultivos convencionais estaqueados em campo aberto no estado de Goiás. ( ) correspondem aos 10 cultivos onde foram coletados os dados de abundância no ano de 2010 e (•) correspondem aos 14 cultivos no ano de 2011. Linhas verticais indicam 1,96 vezes o desvio padrão. (Prop) Proporção de vegetação nativa, (rLPS) tamanho relativo do maior fragmento e (Obsv. time) tempo de observação. Variáveis preditoras selecionadas: Prop. $1 \mathrm{~km}, 1,5 \mathrm{~km}, 2 \mathrm{~km}, 3 \mathrm{~km}$ e rLPS $2 \mathrm{~km}$ e $3 \mathrm{~km}$. Standardized coefficient: coeficiente padronizado da abundância de abelhas. 
As distâncias da vegetação nativa aos cultivos de tomate foram pequenas (média $=196 \mathrm{~m}$, range $=10 \mathrm{~m}$ a $539 \mathrm{~m}$, Anexo) e não houve relação significativa entre a distância e a abundância de abelhas nativas (Tabela 5). Esta ausência de efeito foi consistente entre os anos, com pouca variância explicada pelo efeito aleatório do ano (Tabela 5).

Tabela 5. Relação entre a distância dos remanescentes de vegetação nativa mais próximos dos cultivos de tomateiro e a abundância de cinco grupos de abelhas nas flores do tomateiro em 10 cultivos convencionais estaqueados em campo aberto no ano de 2010 e nos 14 cultivos em 2011 no estado de Goiás. Os pequenos valores de variância nas inclinações do efeito aleatório do ano indicam que as respostas em ambos os anos foram similares.

\begin{tabular}{lccc}
\hline Grupos & $\begin{array}{c}\text { Distância } \\
\text { t-value }\end{array}$ & P & $\begin{array}{c}\text { Variância } \\
\text { efeito aleatória do ano }\end{array}$ \\
\hline Buzzers & 1,394 & 0,370 & $<0,001$ \\
Exomalopsis & 1,290 & 0,410 & $<0,001$ \\
Halictidae & 0,173 & 0,865 & $<0,001$ \\
Centris & 0,924 & 0,464 & $<0,001$ \\
Bombus/Eulaema & 1,690 & 0,255 & $<0,001$ \\
\hline
\end{tabular}

\section{Discussão}

Os resultados desse estudo mostram que o contexto da paisagem influenciou a abundância dos cinco grupos de polinizadores do tomateiro. No entanto, comparações baseadas em nossas inferências com regiões de baixa ocupação agrícola e próximas a 
áreas contínuas e extensas de vegetação nativa devem ser feitas com cuidado. Apesar da paisagem intensamente fragmentada, não houve um padrão geral para todos os grupos. O padrão apresentado pelo grupo Buzzers, que inclui todas as abelhas, refletiu bastante o padrão do grupo de espécies do gênero Exomalopsis, mostrando que essas espécies são importantes polinizadores no sistema estudado. Uma revisão recente que incluiu 785 espécies de abelhas mostra que uma pequena minoria de espécies de abelhas comuns é capaz de fornecer a maioria dos serviços de polinização das culturas estudadas (Kleijn et al. 2015), o que apoia a importância de identificar esses grupos de espécies, tal como proposto em nosso estudo.

A fragmentação da vegetação nativa teve um efeito positivo sobre a abundância de todos os grupos de polinizadores em pelo menos um dos anos do estudo, exceto o grupo Centris. Estes dados sugerem que as abelhas do Cerrado podem ser naturalmente adaptadas para viver em um ambiente fragmentado, pois o Bioma Cerrado é composto por um mosaico de diferentes tipos de vegetação que variam de áreas florestais a campos abertos com formação herbácea (Oliveira-Filho \& Ratter 2002). Além disso, a vegetação da área de estudo foi fragmentada há muito tempo e as espécies de abelhas existentes na comunidade local podem ter sido selecionadas a viver em ambientes perturbados. Por exemplo, indivíduos de Eulaema nigrita possuem maior comportamento de forrageamento em áreas abertas (Tonhasca Jr. et al. 2003; Brosi 2009; Pinto et al. 2015) e sua abundancia é maior em áreas fragmentadas (Tonhasca Jr. et al. 2003). Eulaema nigrita e outras espécies de abelhas nativas podem se alimentar de néctar e pólen de espécies de plantas ruderais ou de espécies de plantas nativas que ocorrem naturalmente em áreas abertas de Cerrado e nas áreas de pastagens. Além disso, estudos fenológicos da vegetação de Cerrado mostraram que é possível encontrar espécies florescendo ao longo do ano, indicando a disponibilidade de recursos para 
polinizadores (Oliveira \& Gibbs 2002). Isto sugere a vagilidade de muitas espécies de polinizadores, uma vez que eles devem ser capazes de usar recursos diferentes intercalados nos diferentes componentes da paisagem.

Uma vez que os efeitos positivos de fragmentação ocorreram frequentemente em conjunto com os efeitos positivos da quantidade de habitat, existe uma dependência de habitats naturais e um efeito da configuração desse habitat, provavelmente relacionado à diversidade de habitats maior em paisagens fragmentadas (Tscharntke et al. 2002b). Esse resultado demonstra a importância da conservação mesmo de pequenos fragmentos, uma vez que esses podem ser responsáveis por aumentar a diversidade de habitats e fornecer recursos cruciais para manutenção de algumas espécies, principalmente espécies com alta mobilidade (Tscharntke et al. 2002b; Rueda et al. 2013).

O grupo Exomalopsis respondeu na escala menor enquanto que os grupos Centris e Halictidae em escalas maiores, sendo que para este último houve maior variabilidade na resposta nos dois anos. Uma provável explicação para a diferença nas escalas entre os grupos Exomalopsis e Centris seria a capacidade de voo das espécies, que por sua vez é influenciada pelo tamanho do corpo (Gathmann \& Tscharntke 2002; Greenleaf et al. 2007). Abelhas de tamanho pequeno forrageiam em escalas de paisagem menores, enquanto abelhas de tamanho grande, voam em escalas de paisagem maiores, até cinco quilômetros (Osborne et al. 1999; Walther-Hellwig \& Frankl 2000; Knight et al. 2005; Lepais et al. 2010). Essa diferença na resposta entre as espécies pode ser um importante mecanismo promovendo a estabilidade desse serviço ecossistêmico (Winfree \& Kremen 2009).

Os grupos Exomalopsis e Centris apresentaram respostas consistentes nos dois anos de estudo enquanto os outros grupos mostraram respostas diferentes. Essa variação 
pode ser explicada por dois processos principais. O primeiro seria a presença de alguma flutuação temporal em condições ou recursos que afetem o tamanho das populações de abelhas desses grupos, pois populações de insetos, especialmente abelhas apresentam grande flutuações de ano para ano, nas estações e no espaço (e.g. Roubik 2001; Williams et al. 2001). O segundo seria uma mudança espacial/temporal na composição de espécies de abelhas entre os anos. Por exemplo, apesar das espécies da família Halictidae possuírem grande semelhança morfológica, o que torna difícil a identificação específica em campo, esta família apresenta muita variação em seus atributos de histórias de vida (Jauker et al. 2013). Assim, os resultados inconsistentes para este grupo podem estar relacionados à mudança de composição de espécies de um ano para outro. Portanto, para esse grupo seria importante conduzir futuros trabalhos como este somente se for possível estabelecer mais precisamente a relação entre a identidade do grupo e seus atributos ecológicos.

Não houve relação entre abundância dos grupos e a distância do fragmento nos dois anos de estudo. Uma provável explicação para ausência de relação seria que em nosso estudo as distâncias do cultivo de tomateiro de manchas de vegetação natural foram pequenas. Isso ocorre porque os cultivos são próximos de cursos de água devido a necessidade de irrigação, e geralmente próximos a estes cursos de água há vegetação nativa. Numa meta-analise, envolvendo 16 cultivos em cinco continentes, observou-se um acentuado declínio da taxa de visitas de polinizadores nativos com o aumento da distância das áreas naturais, sendo que a taxa de visitas reduziu pela metade em 0,6 Km (Ricketts et al. 2008), o que significa mais que três vezes a distância média das áreas naturais aos cultivos de tomateiro no presente estudo. Outra explicação seria que as espécies presentes na área de estudo possuem um conjunto de características que fazem com que não respondam à distância da vegetação nativa nessa escala pequena. Estudos 
mostram que determinadas combinações de atributos das espécies, tais como tamanho do corpo, grau de socialidade e tipo de substrato de nidificação podem influenciar na resposta em relação a distância dos fragmentos (Klein et al. 2003; Ricketts et al. 2008; Jauker et al. 2013).

A influência do contexto da paisagem sobre a abundância e riqueza de abelhas nativas nos agroecossistemas é pouco estudada nas regiões tropicais. No entanto, este assunto é extremamente importante e deveria ser levado em conta nos planos de manejo da paisagem, pois ajudaria na conservação das abelhas e, consequentemente, melhoraria os serviços de polinização e a produção de alimentos. Os resultados obtidos nesse estudo reforçam a necessidade de manutenção dos habitats naturais no entorno das áreas de plantio, mesmo que fragmentadas, para a manutenção da assembleia de polinizadores do tomateiro. Uma vez que o cultivo fornece apenas pólen como recurso alimentar para seus polinizadores, restrito a alguns meses do ano, as abelhas necessariamente dependem de recursos complementares como alimento alternativo e locais de nidificação obtidos em outras fontes. Esse trabalho mostra a importância de se considerar além da perda de habitat (Fahrig 2013) os efeitos da fragmentação sobre a biodiversidade e os serviços ecossistêmicos que a biodiversidade provê. Por último, estudos em múltiplas escalas são crucias para detectar a importância do contexto da paisagem na assembleia de polinizadores locais (Steffan-Dewenter et. al. 2002; Taki et al. 2010).

\section{Referências bibliográficas}

Aizen, M. A., Feinsinger, P. (1994) Habitat fragmentation, native insect pollinators, and feral honey bees in Argentine "Chaco Serrano." Ecological Applications, 4, $378-392$. 
Allen-Wardell, G., Bernhardt, P., Bitner, R., Burquez, A., Buchmann, S., Cane, J., Cox, P., Dalton, V., Feinsinger, P., Ingram, M., Inouye, D., Jones, C., Kennedy, K., Kevan, P., Koopowitz, H., Medellin, R., Medellin-Morales, S., Nabhan, G., Pavlik, B., Tepedino, V., Torchio, P. \& Walker, S. (1998) The potential consequences of pollinator declines on the conservation of biodiversity and stability of food crop yields. Conservation Biology, 12, 8-17.

Bartoń, K. (2015) MuMIn: Multi-Model Inference. R package version.1.15.1.<http://CRAN.R-project.org/package=MuMIn>Acesso em: 05 de novembro de 2015 .

Bascompte, J., Sole, R. (1996) Habitat fragmentation and extinction thersholds in spatially explicit models. Journal of Animal Ecology, 65, 465-473.

Bates, D., Maechler,M., Bolker, B., Walker, S. (2015) Fitting Linear Mixed-Effects Models Using lme4. Journal of Statistical Software, 67, 1-48.

Bivand, R., Lewin-Koh, N. (2015) Maptools: Tools for Reading and Handling Spatial $\begin{array}{lllll}\text { Objects. } & \mathrm{R} \quad \text { Package } & \text { Version } & \text { 0.36. } & \text { http://CRAN.R- }\end{array}$ project.org/package=maptools $>$ Acesso em: 05 de novembro de 2015.

Bivand, R., Keitt, T., Rowlingson, B. (2015) Rgdal: Bindings for the geospatial data abstraction library. $\mathrm{R}$ Package Version 1.0-4. <http://CRAN.Rproject.org/package $=$ rgdal $>$ Acesso em: 05 de novembro de 2015.

Benjamin, F.E., Reilly, J.R., Winfree, R. (2014) Pollinator body size mediates the scale at which land use drives crop pollination services. Journal of Applied Ecology, 51, 440-449.

Brosi, B.J. (2009) The effects of forest fragmentation on euglossine bee communities (Hymenoptera: Apidae: Euglossini). Biological Conservation, 142, 414-423. 
Burnham, K.P., Anderson, D.R. (2002) Model selection and multimodel inference: a practical information-theoretic approach. Springer-Verlag, New York, USA.

Buchmann, S. L. 1983. Buzz pollination in Angiosperms. In C. E. Jones, and R. J. C. P. Little editors. Handbook of experimental pollination biology. Van Nostrand Reinhold Company Inc. 1-274 p.

Deprá, M.S., Delaqua, G.C.G., Freitas, L., Gaglianone, M.C. (2014) Pollination deficit in open-field tomato crops (Solanum lycopersicum L., Solanaceae) in Rio de Janeiro state, Southeast Brazil. Journal of Pollination Ecology, 12 , 1-8.

Fahrig L. (2003) Effects of habitat fragmentation on biodiversity. Annual Review of Ecology, Evolution and Systematics. 34, 487-515.

Fahrig, L. (2013) Rethinking patch size and isolation effects: the habitat amount hypothesis. Journal of Biogeography, 40, 1649-1663.

Fontes, P., Silva, D. (2002) Produção de tomate de mesa. Aprenda Fácil Editora, Viçosa, 193 p.

Fürst, M.A., McMahon, D.P., Osborne, J.L., Paxton, R.J., Brown, M.J.F (2014) Disease associations between honeybees and bumblebees as a threat to wild pollinators. Nature, 506, 364-366.

Gathmann, A., Tscharntke, T. (2002) Foraging ranges of solitary bees. Journal of Animal Ecology, 71, 757-764.

Goulson, D., Hanley, M.E., Darvill, B., Ellis, J., Knight, M.E. (2005) Causes of rarity in bumblebees. Biological Conservation, 122,1-8.

Goulson, D., Nicholls, E., Botías, C., Rotheray, E.L. (2015) Bee declines driven by combined stress from parasites, pesticides, and lack of flowers. Science. <http://www.sciencemag.org/cgi/doi/10.1126/science.1255957> Acesso em: 05 de abril de 2015. 
Greenleaf, S.S., Kremen, C. (2006) Wild bee species increase tomato production and respond differently to surrounding land use in Northern California. Biological Conservation, 3, 81-87.

Greenleaf, S.S., Williams, N.M., Winfree, R., Kremen, C. (2007) Bee foraging ranges and their relationship to body size. Oecologia, 153, 589-596.

IBGE (2015) Sistema IBGE de Recuperação Automática - SIDRA. Available: site.<http://www.sidra.gov.br/bda/tabela/listabl.asp>. Acesso em: 12 de junho de 2015.

Heinzl, H., Mittlböck, M. (2003) Pseudo R-squared measures for Poisson regression models with over or underdispersion. Computational Statistics \& Data Analysis, 44, 253-271.

Hijmans, R.J. (2015) Raster: Geographic data analysis and modeling. R Package Version 2.4-15. <http://CRAN.R-project.org/package=raster> Acesso em: 12 de novembro de 2015 .

Jauker, B., Krauss, J., Jauker, F. \& Steffan-Dewenter, I. (2013) Linking life history traits to pollinator loss in fragmented calcareous grasslands. Landscape Ecology, 28, $107-120$.

Kearns, C.A., Inouye, D.W., Waser, N.M. (1998) Endangered mutualisms: The conservation of plant-pollinator interactions. Annual Review of Ecology and Systematics, 29, 83-112.

Kevan, P.G. (1977) Blueberry crops in Nova Scotia and New Brunswick - Pesticides and crop reductions. Canadian Journal of Agricultural Economics, 25, 61-64. 
Kleijn, D., Winfree, R., Bartomeus, I., Carvalheiro, L.G., Henry, M., Isaacs, R., Klein, A-M., Kremen, C., M’Gonigle, L.K., Rader, R., Ricketts, T.H., Williams, N.M., Adamson, N.L., Ascher, J.S., Báldi, A., Batáry, P., Benjamin, F., Biesmeijer, J.C., Blitzer, E.J., Bommarco, R., Brand, M.R., Bretagnolle, V., Button, L., Cariveau, D.P., Chifflet, R., Colville, J.F., Danforth, B.N., Elle, E., Garratt, M.P.D., Herzog, F., Holzschuh, A., Howlett, B.G., Jauker, F., Jha, S., Knop, E., Krewenka, K.M., Le Féon, V., Mandelik, Y., May, E.A., Park, M.G., Pisanty, G., Reemer, M., Riedinger, V., Rollin, O., Rundlöf, M., Sardinas, H. S., Scheper, J., Sciligo, A.R., Smith, H.G., Steffan-Dewenter, I., Thorp, R., Tscharntke, T., Verhulst, J., Viana, B.F., Vaissière, B.E., Veldtman, R., Westphal, C., Potts, S.G. (2015) Delivery of crop pollination services is an insufficient argument for wild pollinator conservation. Nature Communications, 6, 7414.

Klein, A.M., Steffan-Dewenter, I., Tscharntke, T. (2003) Pollination of Coffea canephora in relation to local and regional agroforestry management. Journal Applied Ecology, 40, 837-845.

Klein, A.M., Vaissiere, B.E., Cane, J.H., Steffan-Dewenter, I., Cunningham, S.A., Kremen, C., Tscharntke, T. (2007) Importance of pollinators in changing landscapes for world crops. Proceedings of the Royal Society B, 274, 303-313.

Knight, M.E., Martin, A.P., Bishop, S., Osborne, J.L., Hale, R.J., Sanderson, R.A., Goulson, D. (2005) An interspecific comparison of foraging range and nest density of four bumblebee (Bombus) species. Molecular Ecology, 14, 18111820.

Kruess, A., Tscharntke, T. (1994) Habitat fragmentation, species loss, and biological control. Science, 264, 1581-1584. 
Lepais, O., Darvill, B., O'Connor, S., Osborne, J.L., Sanderson, R.A., Cussans, J., Goffe, L., Goulson, D. (2010) Estimation of bumblebee queen dispersal distances using sibship reconstruction method. Molecular Ecology, 19, 819-831. McGregor, S.E. (1976) Insect pollination of cultivated crop plants. Agricultural. Research Service, United States Department of Agriculture, Washington DC, USA.

Melo-Silva, C., Gomes, F.L., Gonçalves, B.B., Bergamini, L.L., Bergamini, B.A.R., Elias, M.A.S., Franceschinelli, E.V. (2013) Native bees pollinate tomato flowers and increase fruit production. Journal of Pollination Ecology, 11, 41-45.

Michener, C.D. (2001) The bees of the world. Johns Hopkins University Press, Baltimore, USA, $913 \mathrm{p}$.

Montoya, D., Albuquerque, F.S., Rueda, M., Rodríguez, M.A. (2010) Species response patterns to habitat fragmentation: do trees support the extinction threshold hypothesis? Oikos, 119, 1335-1343.

Morandin, L.A., Winston, M.L., Abbott, V.A., Franklin, M.T. (2007) Can pastureland increase wild bee abundance in agriculturally intense areas? Basic and Applied Ecology, 8, 117-124.

Nunes-Silva, P., Hrncir, M., Imperatriz-Fonseca, V.L. (2010) A polinização por vibração. Oecologia Australis, 14, 140-151.

Ollerton, J., Winfree, R., Tarrant, S. (2011) How many flowering plants are pollinated by animals? Oikos, 120, 321-326.

Osborne, J.L., Clark, S.J., Morris, R.J., Williams, I.H., Riley, J.R., Smith, A.D., Reynolds, D.R., Edwards, A.S. (1999) A landscape-scale study of bumble bee foraging range and constancy, using harmonic radar. Journal of Applied Ecology, 36, 519-533. 
Oliveira-Filho, A.T., Ratter, J.A. (2002) Vegetation physiognomies and woody flora of the cerrado biome. The cerrados of Brazil: Ecology and Natural History of a Neotropical Savanna ( Ed. by Oliveira, P.S. \& Marquis, R. J.), Columbia University Press, New York, USA, 91-120 p.

Oliveira, P.E., Gibbs, P.E. (2002) Pollination and reproductive biology in cerrado plant communities. The cerrados of Brazil: Ecology and Natural History of a Neotropical Savanna ( Ed. by Oliveira, P.S. \& Marquis, R.J. ), Columbia University Press, New York, USA, 329-347 p.

Pinto, N.S., Silva, D.P., Rodrigues, J.G., De Marco, P.Jr. (2015) The size but not the symmetry of the wings of Eulaema nigrita Lepeletier (Apidae: Euglossini) is affected by human-disturbed landscapes in the brazilian cerrado savanna. Neotropical Entomology, 44, 439-447.

Potts, S., Biesmeijer, K., Bommarco, R., Breeze, T., Carvalheiro, L., Franzén, M., González-Varo, J.P., Holzschuh, A., Kleijn, D., Klein, A.M., Kunin, B., Lecocq, T., Lundin, O., Michez, D., Neumann, P., Nieto, A., Penev, L., Rasmont, P., Ratamäki, O., Riedinger, V., Roberts, S., Rundlöf, M., Scheper, J., Sørensen, P., Steffan-Dewenter, I., Stoev, P., Vilà, M., Schweiger, O. (2015) Status and Trends of European Pollinators. Pensoft Publishers, Sofia, BG.

Potts, S.G., Biesmeijer, J.C., Kremen, C., Neumann, P., Schweiger, O., Kunin, W.E. (2010) Global pollinator declines: trends, impacts and drivers. Trends in Ecology \& Evolution, 25, 345-53.

R Core Team (2015) R: a language and environment for statistical computing. R Foundation for Statistical Computing, Vienna, Austria. 
Ricketts, T.H., Daily, G.C., Ehrlich, P.R., Michener, C.D. (2004) Economic value of tropical forest to coffee production. Proceedings of the National Academy of Sciences of the United States of America, 101, 12579-12582.

Ricketts, T.H, Regetz, J., Steffan-Dewenter, I., Cunningham, S.A., Kremen, C., Bogdanski, A., Gemmill-Herren, B., Greenleaf, S.S., Klein, M.A., Mayfield, M.M., Morandin, L.A., Ochieng, A, Potts, S.G., Viana, B.F. (2008) Landscape effects on crop pollination services: Are there general patterns? Ecology Letters, 11, 499-515.

Roubik, D. W. (2001) Ups and downs in pollinator populations: When is there a decline? Conservation Ecology, 5, 2.

Rueda, M., Hawkins, B.A., Morales-Castilha, I., Vidanes, R.M., Ferrero, M., Rodríguez, M. Á. (2013) Does fragmentation increase extinction thresholds? A European-wide test with seven forest birds. Global Ecology and Biogeography, 22, 1282-1292.

Steffan-Dewenter, I., Kuhn, A. (2003) Honeybee foraging in differentially structured landscapes. Proceedings of the Royal Society B, 270, 569-575.

Steffan-Dewenter, I. (2003) Importance of habitat area and landscape context for species richness of bees and wasps in fragmented orchard meadows. Conservation Biology, 17, 1036-1044.

Steffan-Dewenter, I., Münzenberg, U., Bürger, C., Thies, C., Tscharntke, T. (2002) Scale-dependant effects of landscape context on three pollinator guilds. Ecology, 83, 1421-1432. 
Taki, H., Okabe, K., Yamaura, Y., Matsuura, T., Sueyoshi, M., Makino, S., Maeto, K. (2010) Effects of landscape metrics on Apis and non-Apis pollinators and seed set in common buckwheat. Basic and Applied Ecology, 11, 594-602.

Tonhasca Jr., A., Albuquerque, G.S., Blackmer, J.L. (2003) Dispersal of euglossine bees between fragments of the Brazilian Atlantic Forest. Journal of Tropical Ecology, 19, 99-102.

Tscharntke, T., Steffan-Dewenter, I., Kruess, A., Thies, C. (2002b) Contribution of small habitat fragments to conservation of insect communities of grasslandcropland landscapes. Ecological Applications, 12, 354-363.

Viana, B.F., Boscolo, D., Neto, E.M., Lopes, L.E., Lopes, A.V., Ferreira, P.A., Pigozzo, C.M., Primo, L.M. (2012) How well do we understand landscape effects on pollinators and pollination services. Journal of Pollination Ecology, 7, 31-41.

Walther-Hellwig, K., Frankl, R. (2000) Foraging habitats and foraging distances of bumblebees, Bombus spp. (Hym., Apidae), in an agricultural landscape. Journal of Applied Entomology, 124, 299-306.

Whitehorn, P.R., O'Connor, S., Wackers, F.L., Goulson, D. (2012) Neonicotinoid pesticide reduces bumble bee colony growth and queen production. Science, 336, 351-352.

Williams, N.M., Minckley, R.L., Silveira, F.A. (2001) Variation in native bee faunas and its implications for detecting community changes. Conservation Ecology, 5, 7.

Winfree, R., Kremen, C. (2009) Are ecosystem services stabilized by differences among species? A test using crop pollination. Proceedings of the Royal Society B, 276, 229-237. 
Capítulo II

Avaliação de danos ao DNA em abelhas Melipona quadrisfaciata expostas in vivo a concentrações subletais dos inseticidas imidacloprid e deltametrina 


\section{Resumo}

Abelhas são os principais polinizadores de plantas nativas nos ecossistemas terrestres e indispensáveis ao serviço ecossistêmico de polinização. Ao realizar o serviço de polinização em cultivos agrícolas elas são expostas direta e indiretamente a inseticidas, tais como o imidacloprid e a deltametrina comumente usados em uma variedade de cultivos, entre eles o tomateiro. Atualmente os inseticidas são considerados uma das principais ameaças às abelhas em todo o mundo. Sendo assim, o objetivo do presente estudo foi avaliar, em condições de laboratório, os possíveis efeitos genotóxicos, danos ao DNA, causados pelo imidacloprid e deltametrina em abelhas operárias da espécie Melipona quadrisfaciata. As abelhas foram divididas em um grupo controle e quatro grupos experimentais, e expostas a duas concentrações subletais de imidacloprid e duas de deltametrina presentes em sacarose a $50 \%$ por um período de 72 horas. Decorrido esse tempo, o ensaio cometa foi realizado para detectar danos ao DNA nas células de defesa, hemócitos, presentes na hemolinfa das abelhas operárias. Aumento significativo de danos ao DNA (conforme indicado pelo momento da cauda de Olive) foi detectado em hemócitos de abelhas expostas às duas concentrações subletais do inseticida deltametrina quando comparado com o inseticida imidacloprid e com o controle negativo. Esse é o primeiro estudo a analisar os efeitos genotóxicos de inseticidas em abelhas nativas do Brasil.

Palavras-chaves: Ensaio cometa, imidacloprid, deltametrina, genotoxicidade, hemócitos, momento da cauda de Olive. 


\title{
Evaluation of DNA damage in bees Melipona quadrifasciata L. exposure in vivo to subletal concentrations of two inseticides using the comet assay
}

\begin{abstract}
Bees are the main pollinators of native and cultivated plants, offering essential pollination service to the ecosystem. Upon pollination service in agricultural crops, bees are exposed directly or indirectly to insecticides, such as imidacloprid and deltamethrin. These insecticides are commonly used in a variety of crops, including tomato. Currently pesticides are considered major threats to bees worldwide. Thus, the aim of this study is to evaluate, in laboratory conditions, potential genotoxic effects, and the DNA damage caused by imidacloprid and deltamethrin in haemocytes of worker bees of Melipona quadrifasciata, species that is often found in tomato crops. Bees were shared into four experimental groups and one control, and exposed to two sublethal concentrations present in 50\% sucrose for each insecticide during a period of 72 hours. After this time, the comet assay was performed to detect DNA damage in immune cells present in the haemolymph of worker bees. A significant increase in DNA damage (as indicated by the Olive tail moment) was found in haemocytes of bees exposed to both sublethal concentrations of insecticide deltamethrin when compared with the insecticide imidacloprid and the negative control. To our knowledge, this is the first study to examine the genotoxic effects of insecticides on bees.
\end{abstract}

Keywords: Comet Assay, imidacloprid, deltamethrin, genotoxicity, hemocytes, Olive tail moment. 


\section{Introdução}

Abelhas são os principais polinizadores de plantas nativas e cultivadas nos ecossistemas terrestres (Delaplane \& Mayer 2000; FAO 2004; Klein et al. 2007). Vários estudos têm demonstrado a importância econômica do serviço de polinização e os potenciais riscos do declínio dos polinizadores (Costanza et al.1997; Klein et al. 2007; Gallai et al. 2009; Potts et al. 2010; Bauer \& Wing 2010, Giannini et al. 2015). Contudo, há claras evidências do declínio de populações de abelhas nativas e manejadas (Biesmeijer et al. 2006; Potts et al. 2010, VanEngelsdorp \& Meixner 2010), tendo como possíveis causas a perda de habitat, fragmentação, mudança climática, doenças, patógenos e agrotóxicos, principalmente inseticidas (Kevan \& Imperatriz-Fonseca 2006; Aizen et al. 2008; Potts et al. 2010; VanEngelsdorp \& Meixner 2010; Potts et al. 2010; Goulson et al. 2015).

O Brasil é considerado um dos maiores consumidores de agrotóxicos do planeta. Em 2007 houve um consumo de 730 milhões de toneladas. Cerca de 30\% desse total eram inseticidas (Nocelli et al. 2012), dentre os quais, aproximadamente $40 \%$ são considerados tóxicos para as abelhas (Menten 2009). Dentre os grupos considerados tóxicos para abelhas, os inseticidas do grupo químico dos neonicotinóides tem sido foco de um intenso debate e preocupação mundial em função do desaparecimento das abelhas (Blacquière et al. 2012; European Food Safety Authority 2013; Gross 2013). No Brasil, os neonicotinóides são utilizados largamente em uma variedade de cultivos. Outro grupo altamente tóxico para as abelhas é o grupo dos piretróides (Inglesfield 1989; Johnson et al. 2010). Estudos demonstram que inseticidas desses grupos químicos causam morte ou efeitos subletais nas abelhas manejadas e nativas (Stevenson 1978; Nation et al. 1986; Desneux et al. 2007; Thomazoni et al. 2009; Carvalho et al. 2009; Whitehorn et al 2012). 
Existem vários inseticidas disponíveis no mercado com princípios ativos pertencentes a esses dois grupos. Dentre eles, podemos citar o imidacloprid, que pertence ao grupo dos neonicotinóides e a deltametrina, que pertence ao grupo dos piretróides. Imidacloprid é o princípio ativo mais usado no mundo no controle de pragas e doenças agrícolas (Freitas \& Pinheiro 2010) e juntamente com a deltametrina são utilizados numa ampla variedade de culturas, entre elas a do tomate (MAPA 2015). Em 2008, a deltametrina foi um dos inseticidas mais comercializados para uso em cultivos de tomate convencional estaqueado de mesa em Goiás (Latorraca et al. 2008). Esses cultivos são frequentemente visitados por abelhas em busca de pólen (Nunes-Silva et. al. 2010).

Estudos sobre a toxicidade do ingrediente ativo imidacloprid mostraram que doses subletais induziram necroses em glândulas hipofaringeanas de abelhas operárias em 48 horas após o tratamento, morte apoptótica em células do intestino médio, redução do ciclo de postura da rainha, diminuição da atividade locomotora, redução no forrrageamento e capacidade de voo (Schmuck et al. 2001; Skerl \& Gregorc 2010; Gregorc \& Ellis 2011; Schneider et al. 2012). O ingrediente ativo deltametrina também tem mostrado que suas doses subletais induzem a distúrbios fisiológicos e comportamentais graves (Vandame et al. 1995; Belzunces et al. 2001; Thompson 2002; Decourtye et al. 2004, 2005). Portanto, seria interessante também verificar se há danos ao DNA, ou seja, genotoxicidade, em abelhas que coletam néctar ou pólen em cultivos agrícolas que utilizam tais inseticidas, pois esses danos têm implicações para sobrevivência e reprodução caso ajam falhas nos mecanismos de reparação.

O gênero Melipona pertence à tribo Meliponini e apresenta distribuição geográfica exclusivamente neotropical (Michener 2007). Este gênero compreende mais de 40 espécies conhecidas (Camargo 1979; Michener 1979). Dentre os meliponíneos, a 
espécie Melipona quadrisfacita Lepeletier 1836 é considerada um importante polinizador do tomateiro em cultivo protegido (Del Sarto et al. 2005; Santos et al. 2009; Nunes-Silva et. al. 2010), podendo ser afetada direta e indiretamente por compostos tóxicos pulverizados em cultivos de tomateiro. Tal fato, sugere que esta espécie pode sofrer danos no DNA causados por inseticidas.

Nas últimas décadas, um grande número de estudos experimentais foi realizado sobre os danos ao DNA induzidos por pesticidas em algumas espécies de roedores, peixes, anfíbios, moluscos, minhocas e insetos (Frantzios et al. 2008, Azqueta et al. 2015, Lapuente et al. 2015). Contudo, não há estudos sobre os danos causados ao DNA de abelhas e induzidos por inseticidas. Danos ao DNA (quebras de fitas simples, duplas, crosslinks, sítios de reparos ou por excisão e/ou lesões álcali-lábeis) representam potenciais lesões mutagênicas (Cook et al. 2003). O grau de integridade do DNA tem sido proposto como um sensível indicador de genotoxicidade para biomonitoramento de ecossistemas terrestes e aquáticos (Azqueta et al. 2015). No presente estudo, o objetivo foi avaliar a genotoxicidade dos inseticidas imidacloprid e deltametrina usando o ensaio cometa para detectar o dano ao DNA em células da hemolinfa, hemócitos, de indivíduos da espécie de abelha nativa Melipona quadrifasciata em condições de laboratório.

\section{Material e métodos}

Os experimentos para determinar a genotoxicidade dos inseticidas imidacloprid e deltametrina foram realizados com operárias adultas de três colônias de abelhas-semferrão, M. quadrifasciata. Essas foram obtidas de colônia domesticada de fornecedor comercial (Meliponário Abelha Jataí, Cambará - PR, Brasil) e são mantidas em condições de campo no viveiro da engenharia florestal da Universidade Federal de Goiás (UFG, Goiânia, Brasil, 16³5’ S, 49²17’W). 


\section{Inseticidas}

Para os experimentos com imidacloprid foi utilizado a formulação comercial: Evidence 700WG (Bayer), composição de $700 \mathrm{~g} / \mathrm{Kg}$ de imidacloprid e de $300 \mathrm{~g} / \mathrm{Kg}$ de outros ingredientes e o tipo de formulação é o granulado dispersível em água. Para os experimentos com deltametrina foi utilizada a formulação comercial: Decis 25 EC (Bayer), composição de $25 \mathrm{~g} / \mathrm{L}$ de deltametrina e de $886 \mathrm{~g} / \mathrm{L}$ de ingredientes inertes e o tipo de formulação é o concentrado emulsionável. Ambos inseticidas utilizados nos experimentos são registrados no Ministério da Agricultura, Pecuária e Abastecimento (MAPA), para a cultura do tomateiro e frequentemente utilizados na região de Goiás.

O imidacloprid é utilizado no controle de tripes (Thrips palmi), pulgão-verde (Myzus persicae), e moscas-brancas (Bemisia tabaci) e a deltrametrina é empregada para o controle da broca-pequena-do-fruto (Neoleucinodes elegantalis), Larva minadora (Lyriomyza sativae), percevejo-rendado (Corythaica cyathicollis), Traça-da-batatinha (Phthorimaea operculella), Vaquinha-verde-amarela (Diabrotica speciosa), Vaquinhadas-solanáceas (Epicauta atomaria), Besouro (Systena tenuis) e Lagarta-rosca (Agrotis ípsilon).

\section{Bioensaios e tratamentos}

As abelhas foram coletadas nas colônias pela manhã, com tubo de plástico de 20 $\mathrm{mm}$, transferidas para caixas de madeira $(15 \times 15 \times 15 \mathrm{~cm})$, e mantidas em estufa BOD, $28^{\circ} \pm 1^{\circ} \mathrm{C}$ e umidade relativa de $70 \% \pm 5 \%$ durante todo o período do experimento. Nas primeiras 48 horas, todas as abelhas foram alimentadas com sacarose 50\%, período considerado de adaptação para minimizar os efeitos causados pelo estresse da manipulação dos indivíduos. 


\section{Alimentação das Abelhas}

Em todos os ensaios realizados, o alimento foi fornecido diariamente ad libidum no período da manhã. Em cada caixa foram colocados dois recipientes de plástico de 10 mL e em cada recipiente de plástico um chumaço de algodão embebido com solução de sacarose $50 \%$ somente ou com solução de sacarose $50 \%$ acrescida do inseticida.

\section{Determinação das Concentrações Subletais}

Para determinar as concentrações subletais máximas de cada um dos inseticidas utilizados, foram utilizadas várias caixas de madeira, cada uma com 15 abelhas que eram mantidas em estufa BOD conforme descrito acima. Após o período de aclimatação, cada caixa passou a receber diariamente uma solução de sacarose $50 \%$ acrescida de diferentes concentrações dos inseticidas pesquisados.

A concentração subletal máxima considerada foi aquela na qual as abelhas apresentaram uma taxa de mortalidade de 20\% (12 abelhas vivas) após três dias de consumo. Para ambos inseticidas testados a concentrção subletal máxima encontrada foi de $2,5 \times 10^{-5} \%$. Os cálculos para se chegar a essa concentração foram feitos a partir das informações fornecidas no rótulo dos produtos: $700 \mathrm{~g} / \mathrm{Kg}$ de imidacloprid e de $300 \mathrm{~g} / \mathrm{Kg}$ de outros ingredientes e $25 \mathrm{~g} / \mathrm{L}$ de deltametrina e de $886 \mathrm{~g} / \mathrm{L}$ de ingredientes inertes. Durante nossos testes, as abelhas não demonstraram rejeição à solução de sacarose contaminada com os inseticidas. 
Grupo controle e grupos xperimentais

Abelhas operárias foram coletadas e mantidas em caixas de madeira em estufa BOD, conforme descrito anteriormente. Após o período de aclimatação, as abelhas passaram a ser alimentadas diariamente por 72 horas, conforme descrito na tabela 1 .

Tabela 1. Divisão e descrição dos grupos experimentais de abelhas da espécie Melipona quadrifasciata expostas a solução de $50 \%$ de sacarose e a solução de $50 \%$ de sacarose acrescida de imidacloprid e deltametrina durante 72 horas.

\begin{tabular}{|c|c|}
\hline Grupo & Descrição \\
\hline Controle negativo & $\begin{array}{l}\text { As abelhas continuaram sendo alimentadas diariamente com } \\
\text { solução de } 50 \% \text { de sacarose por } 72 \text { horas. }\end{array}$ \\
\hline Tratamento 1 & $\begin{array}{l}\text { Abelhas alimentadas com sacarose } 50 \% \text { acrescida de metade da } \\
\text { concentração subletal máxima de imidacloprid }\left(1,25 \times 10^{-5} \%\right) \\
\text { por } 72 \text { horas. }\end{array}$ \\
\hline Tratamento 2 & $\begin{array}{l}\text { Abelhas alimentadas com sacarose } 50 \% \text { acrescida da } \\
\text { concentração subletal máxima de imidacloprid }\left(2,5 \times 10^{-5} \%\right) \text { por } \\
72 \text { horas. }\end{array}$ \\
\hline Tratamento 3 & $\begin{array}{l}\text { Abelhas alimentadas com sacarose } 50 \% \text { acrescida de metade da } \\
\text { concentração subletal máxima de deltametrina }\left(1,25 \times 10^{-5} \%\right) \\
\text { por } 72 \text { horas. }\end{array}$ \\
\hline Tratamento 4 & $\begin{array}{l}\text { Abelhas alimentadas com sacarose } 50 \% \text { acrescida da } \\
\text { concentração subletal máxima de deltametrina }\left(2,5 \times 10^{-5} \%\right) \text { por } \\
72 \text { horas. }\end{array}$ \\
\hline
\end{tabular}


Os experimentos foram realizados em triplicata (três réplicas), totalizando 45 abelhas para cada um dos quatros tratamentos e 45 abelhas para o controle negativo. Cada réplica era constituída de 15 abelhas operárias adultas.

\section{Ensaio cometa}

Abelhas operárias da espécie $M$. quadrifasciata de cada tratamento experimental foram eterizadas, isto é, inseridas em recipientes de vidros, cuja tampa é constituída de um chumaço de tecido, o qual foi embebido em éter antes de fechar os recipientes contendo as abelhas, e transferidas para uma placa escavada contendo solução de EDTA (ácido etilenodiamino tetra-acético) para evitar a coagulação da hemolinfa.

Visualizando-os ao microscópio estereoscópico (Lupa), com a ajuda de uma pinça de relojoeiro $\mathrm{n}^{\mathrm{0}} 5$ e uma seringa de $5 \mathrm{~mL}$ foram realizadas duas lesões em cada indivíduo, uma que transpassava o tórax e uma segunda lesão no abdômen. A hemolinfa depositada no fundo da placa escavada foi retirada com a ajuda de uma micropipeta e colocada em tubos de microcentrífuga $(1,5 \mathrm{~mL})$. A hemolinfa de cada réplica foi misturada em um único tubo, constituindo um pool celular de todos os indivíduos.

Posteriormente, os tubos foram centrifugados. O volume final de solução de ácido etilenodiamino tetra-acético (EDTA) + hemolinfa foi equivalente a $0,5 \mathrm{~mL}$ por tubo. Os tubos foram submetidos à centrifugação por 2 vezes a $3.000 \mathrm{rpm}$ por 3 minutos, sendo descartados $100 \mu \mathrm{L}$ de sobrenadante, seguido do acréscimo de mais $100 \mu \mathrm{L}$ de solução de EDTA, completando o volume do tubo novamente para $0,5 \mathrm{~mL}$, para a terceira centrifugação. Esse procedimento se fez necessário para que todas as impurezas sejam eliminadas, aumentando a qualidade das amostras.

Em seguida, $10 \mu \mathrm{L}$ da suspensão de pool celular de todos os indivíduos foram embebidos em $120 \mu \mathrm{L}$ de agarose "Low Melting Point" a 0,5\%, a qual estava em banho Maria a $37^{\circ} \mathrm{C}$. Essa mistura foi colocada em lâmina preparada com a pré-cobertura de 
agarose "Normal Melting” 1,5\% e coberta com uma lamínula. Esse procedimento foi feito em cinco lâminas por réplica para cada grupo de estudo, considerando que os experimentos foram realizados em triplicata (três réplicas), o total de lâminas para cada grupo foi de 15 lâminas. Na sequencia, as lâminas foram colocadas na geladeira a $4^{\circ} \mathrm{C}$ durante dois minutos para que houvesse a solidificação do material. Após esse tempo as lamínulas foram retiradas e as lâminas então foram imersas em tampão de lise por até 24 horas.

Após 24 horas, as lâminas foram retiradas da lise e colocadas em uma cuba horizontal de eletroforese, incubadas em tampão alcalino deixando descansar por 30 minutos. A corrida eletroforética foi realizada por 25 minutos, a 25 volts e 300 Amps. A neutralização foi feita com uma solução Tampão Tris a $0,4 \mathrm{M}(\mathrm{pH} 7,5)$ por três vezes, durante 5 minutos. Após a neutralização essas lâminas foram lavadas duas vezes com água destilada e colocadas para secar na posição inclinada. A fixação foi feita com etanol absoluto por 5 minutos. O DNA foi corado com $125 \mu \mathrm{L}$ de uma solução contendo Sybr green ${ }^{\circledR}$ e essa lâmina ficou em local escuro por 30 minutos. Em seguida o material corado foi fixado com $20 \mu \mathrm{L}$ do reagente Vectashield ${ }^{\circledR}$. Após a fixação, a lamínula foi novamente colocada sobre a lâmina e todas as lâminas foram analisadas sob microscopia de epifluorescência, utilizando um conjunto de filtros de excitação 515-560 nm, para fluorescência verde. Os nucleóides das células foram visualizados utilizando a objetiva de $20 \mathrm{X}$ e as imagens fluorescentes foram capturadas utilizando o software Comet Assay da MetaSystens ${ }^{\circledR}$.

Cinco lâminas foram analisadas para cada réplica. Em cada lâmina 20 nucleóides das células foram contados aleatoriamente, totalizando 100 nucleóides por réplica. Em cada nucleóide (cometa) foram avaliados: o comprimento da cauda (cc), a porcentagem de DNA na cauda e o momento da cauda de Olive (mco). Este momento é 
o produto da porcentagem de DNA na cauda multiplicado pelo comprimento da cauda (Olive et al. 1990). Uma vez que o momento da cauda de Olive contém tantas informações sobre a porcentagem de DNA na cauda quanto sobre o comprimento da cauda, optou-se por utiliza-lo como a única variável resposta nesse estudo. O método para a avaliação dos danos genotóxicos foi realizado através do programa software “Comet imager" versão 2.2.

\section{Análises estatísticas}

O teste estatístico utilizado para comparar diferenças na variável resposta entre os inseticidas e suas concentrações subletais foi a analise de variância fatorial 2 x 2 com decomposição da soma de quadrado tipo IV. Posteriormente, comparações planejadas foram feitas entre as concentrações subletais dos inseticidas e o controle. Para satisfazer os pressupostos do modelo foi realizada uma transformação logarítmica nos valores da variável resposta. Os testes foram realizados no programa Statistica (versão13).

\section{Resultados}

Os nucleóides dos hemócitos de abelhas operárias de M. quadrifasciata usados para avaliação dos danos ao DNA através do ensaio cometa apresentaram valores médios do momento da cauda de Olive para os inseticidas imidacloprid e deltametrina conforme descritos na Tabela 2. 
Tabela 2. Valores médios e desvio padrão do momento da cauda de Olive (MCO) em hemócitos de abelhas operárias da espécie Melipona quadrifasciata expostas a dois tipos de inseticidas em diferentes concentrações subletais. U.A.: unidade arbitrária.

\begin{tabular}{lcc}
\hline \multicolumn{1}{c}{ Inseticidas } & Tratamento & $\begin{array}{c}\text { Média e desvio padrão MCO } \\
\text { (U.A.) }\end{array}$ \\
\hline Imidacloprid & $1,25 \times 10^{-5} \%$ & $0,62 \pm 0,26$ \\
& $2,5 \times 10^{-5} \%$ & $0,46 \pm 0,11$ \\
& & \\
Deltametrina & $1,25 \times 10^{-5} \%$ & $9,07 \pm 3,05$ \\
Controle negativo & $2,5 \times 10^{-5} \%$ & $9,28 \pm 0,55$ \\
\hline
\end{tabular}

O momento da cauda de Olive foi significativamente diferente entre as abelhas expostas aos inseticidas imidacloprid e deltametrina (Tabela 3), sendo que em média as duas concentrações subletais do inseticida deltametrina causaram aproximadamente 17 vezes mais danos significativos sobre o DNA de hemócitos de abelhas operárias de $M$. quadrifasciata quando comparado com a média das duas concentrações subletais do inseticida imidacloprid (Figura 1). A média das duas concentrações subletais do inseticida deltametrina causou sete vezes mais danos, sendo estatisticamente significativo quando comparado com o controle negativo $(\mathrm{t}=6,688, \mathrm{P}<0,001$, Figura 1$) \mathrm{e}$ não houve diferença significativa entre a média das duas concentrações subletais do inseticida imidacloprid quando comparado com o controle negativo $(\mathrm{t}=-0,828, \mathrm{P}=$ 0,422, Figura 1). Entre as concentrações de $1,25 \times 10^{-5} \%$ e $2,5 \times 10^{-5} \%$ não houve diferença significativa para nenhum dos inseticidas (Tabela 3). 
Tabela 3. Análise de variância testando o efeito entre os inseticidas imidacloprid e deltametrina, entre as concentrações subletais e entre os inseticidas e as concentrações (interação) sobre o momento da cauda de Olive (MCO) em hemócitos de abelhas operárias da espécie Melipona quadrifasciata.

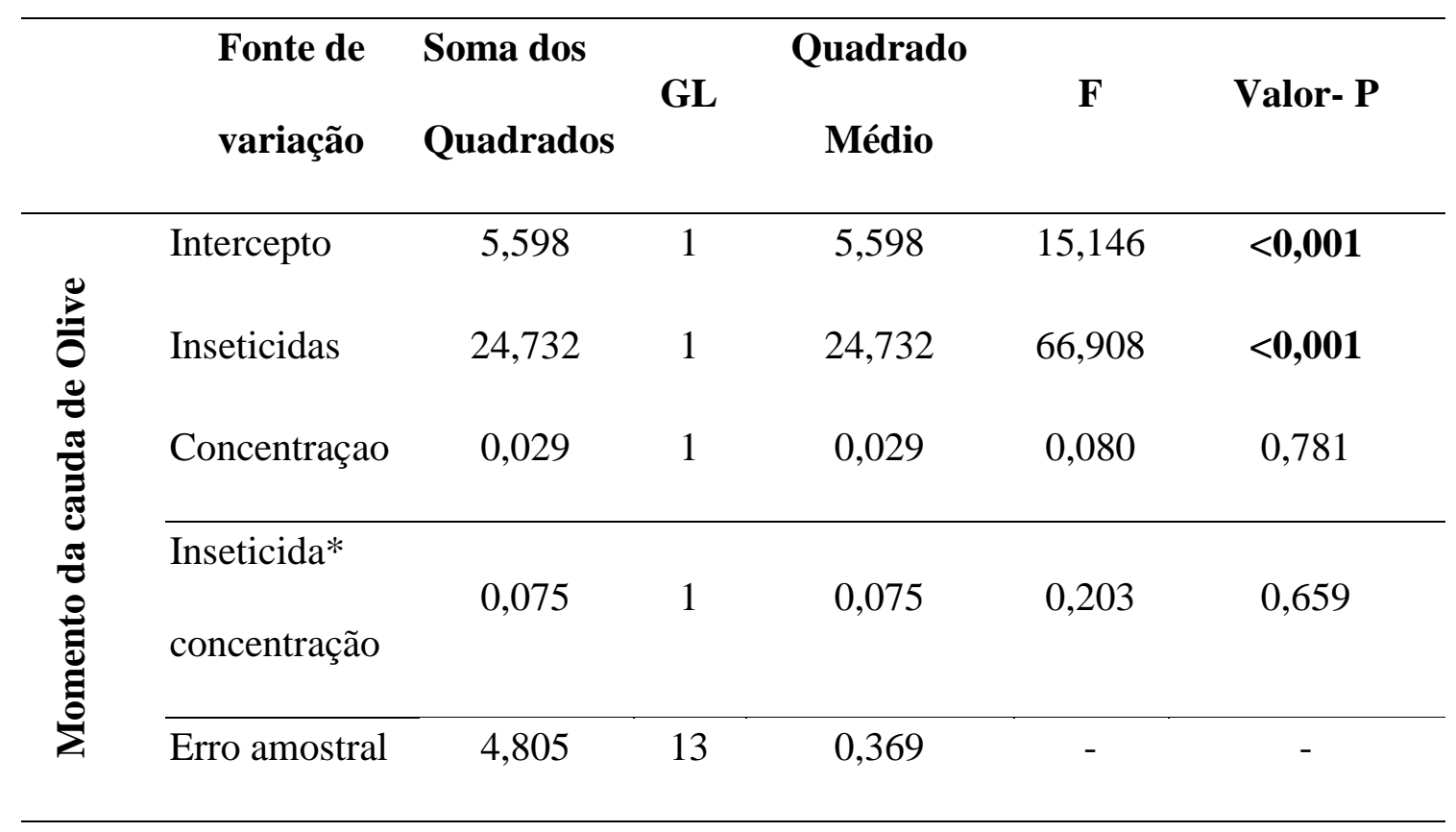




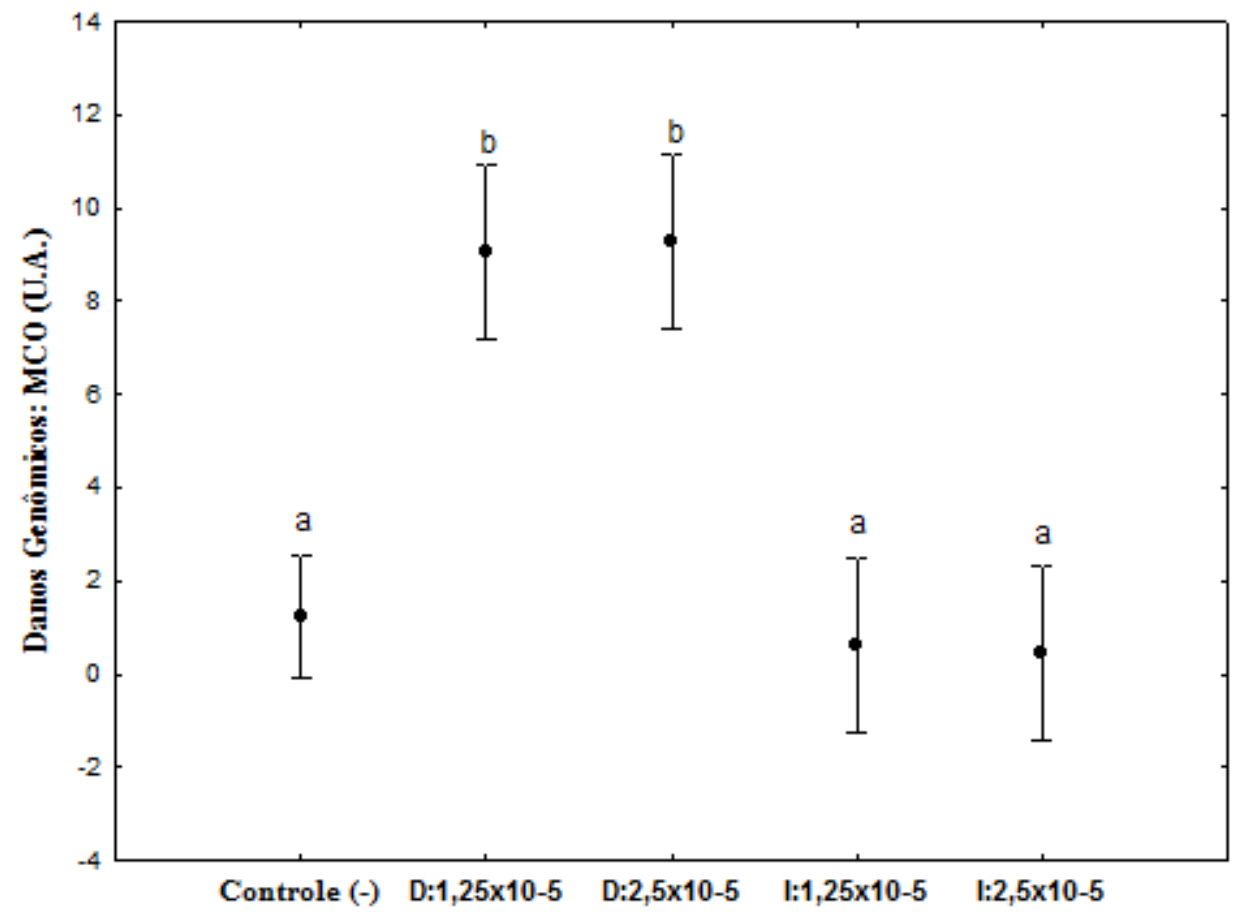

Figura 1. Efeitos de 72 horas de exposição aos inseticidas imidacloprid (I) e deltametrina (D) em duas concentrações subletais (\%) para cada inseticida sobre o DNA de hemócitos de abelhas operárias da espécie Melipona quadrifasciata. MCO corresponde ao momento da cauda de Olive; Controle (-) no eixo x corresponde ao controle negativo; D, corresponde ao inseticida deltametrina em duas concentrações subletais e I, corresponde ao inseticida imidacloprid também em duas concentrações subletais. Círculos preenchidos correspondem a média e linhas verticais indicam o desvio padrão. Letras iguais indicam que não há diferença estatisticamente significativa e letras diferentes indicam diferenças significativas, $\mathrm{P}<0,05$.

\section{Discussão}

Nesse estudo foram avaliados os efeitos genotóxicos das concentrações subletais de inseticidas nas células de defesa de abelhas operárias da espécie $M$. quadrifasciata após a exposição in vivo desses agentes. As concentrações usadas nesse trabalho, embora estabelecidas por meio de ensaios experimentais, não diferem das concentrações 
médias de deltametrina e imidacloprid encontradas no pólen e na cera de abelhas melíferas na América do Norte (Mullin et al. 2010).

Os resultados demonstram que as concentrações testadas de deltametrina foram capazes de causar danos ao DNA (conforme indicado pelo momento da cauda de Olive) dos hemócitos de abelhas quando comparados com o controle. Já as abelhas tratadas com o inseticida imidacloprid não demonstraram danos ao DNA induzidos pelo inseticida quando comparadas com o controle. Frantzios et al. (2008) também não encontraram efeitos genotóxicos do imidacloprid na espécie Drosophila melanogaster para larvas e adultos através do teste de mutação e recombinação somática (SMART). No entanto, estudos sobre a genotoxicidade de imidacloprid detectaram danos ao DNA em minhocas, anfíbios e humanos utilizando o ensaio cometa (Zang et al. 2000, Feng et al. 2004, 2005). De acordo com Frantzios et al. (2008) os resultados divergentes podem estar relacionados a técnica utilizada, ao sistema genético estudado e aos diferentes níveis de exposição.

O ensaio cometa é usado como biomarcardor para danos ao DNA e o aumento de danos é interpretado como prejudicial à saúde do organismo caso haja falha nos mecanismos de reparação (Steinert 1999; Pavlica et al. 2001). Danos ao DNA podem ser associados com redução do crescimento, desenvolvimento anormal e diminuição da sobrevivência e sucesso reprodutivo (Jha 2008). Uma das formas de contaminação em campo das abelhas da espécie $M$. quadifasciata por inseticidas, como por exemplo a deltametrina em concentrações subletais, se daria por meio da coleta de néctar e pólen contaminados, podendo atingir em maior ou menor extensão a colônia (Jay 1986). As abelhas operárias ao se alimentarem de néctar contaminados poderiam acumular danos ao DNA não reparados nas células somáticas, levando ao desenvolvimento de doenças com consequente redução da sobrevivência e adaptabilidade (Adaptdo de Jha 2008). Já 
para a rainha, o zangão e para as futuras gerações as consequências dos danos ao DNA devido a ingestão de alimento contaminado por inseticida seriam mais graves. Ao se alimentarem de néctar e pólen contaminados por inseticida, além da possibilidade da redução na sobrevivência e adaptabilidade devido ao DNA danificado e não reparado, esses indivíduos poderiam ter também seu sucesso reprodutivo reduzido. Em certos casos, os danos poderiam persistir e serem passados para as próximas gerações, afetando negativamente o desenvolvimento, sobrevivência e por fim a persistência da colônia (Adaptdo de Jha 2008). Portanto, nosso estudo sugere que os danos ao DNA causado pelo inseticida deltametrina poderia impactar negativamente a sobrevivência e o sucesso reprodutivo da espécie $M$. quadifasciata com implicações para conservação e os serviços ecossistêmicos.

Em nosso estudo utilizamos baixas concentrações de ambos os inseticidas para verificar o potencial genotóxico nos hemócitos de abelhas operárias da espécie $M$. quadrifasciata como uma tentativa de se aproximar das concentrações residuais de inseticidas presentes no néctar e no pólen de plantas nos cultivos e de plantas ruderais próximas aos cultivos visitados pelas abelhas (Mullin et al. 2010, Blacquière et al. 2012). A ausência de aumento de danos no DNA de abelhas expostas ao inseticida imidacloprid poderia ser resultado do baixo tempo de exposição ou porque a concentração limiar crítica desse inseticida ainda não foi alcançada para detecção de danos através do ensaio cometa. Wang et al. 2015 avaliaram o potencial genotóxico de imidacloprid em uma espécie de minhoca, Eisenia fetida, e não encontraram danos ao DNA nas duas menores concentrações subletais das cinco fornecidas ao indivíduos. Marinowic et al. (2012) verificaram que numa determinada concentração inicial do inseticida ß-cyfluthrin os danos ao DNA na espécie de peixe Bryconamericus iheringii (Characidae) não diferiram do grupo controle, porém uma segunda concentração maior 
do que a primeira e num período de tempo maior verificou-se uma diferença significativa entre os danos deste último tratamento e o grupo controle. Há vários estudos sobre os efeitos subletais em abelhas causados pelo princípio ativo presente no imidacloprid em uma ampla extensão de concentrações subletais utilizadas (Schmuck et al. 2001; Skerl \& Gregorc 2010; Gregorc \& Ellis 2011; Schneider et al. 2012, Tomé et al. 2012). No entanto, Aliouane et al. (2009) verificaram que os neonicotinóides agem como agonistas do sistema colinérgico, provocando excitação em baixas doses e efeitos tóxicos relevantes em altas doses. Os resultados referentes ao imidacloprid encontrados no presente estudo precisam ser avaliados com cautela, já que seria prematuro afirmar que esse pesticida não causa danos ao material genético de $M$. quadrifasciata sem antes se avaliar outras concentrações do inseticida e outros tempos de exposição ao produto. Precisa-se também certificar que outro tipo de estresse celular não está sendo produzido, como por exemplo espécies reativas de oxigênio que além de danificarem a estrutura do DNA são também capazes de atrapalhar o funcionamento de proteínas e enzimas citoplasmáticas.

Por outro lado, o resultado encontrado no presente estudo para deltametrina mostram danos ao DNA mesmo nas baixas concentrações testadas. No entanto, é importante ressaltar que os danos ao DNA nas abelhas podem ser muito maiores para ambos os inseticidas uma vez que concentrações muito maiores e até mesmo misturas de vários inseticidas e fungicidas são aplicados em cultivos como nos de tomate (ReisFilho et al. 2009). Além disso, ainda não foram avaliados possíveis efeitos genotóxicos causados por esses inseticidas quando inseridos na alimentação das larvas de $M$. quadrifasciata, já que os animais são normalmente mais sensíveis a efeitos deletérios durante seu desenvolvimento. 
Entre os piretróides, a deltametrina, é relatada como sendo o mais tóxico, uma vez que não é completamente metabolizada e nem rapidamente desintoxicado, e por conseguinte, cria sérios problemas de acumulação de resíduo, especialmente em tecidos gordurosos, com riscos genotóxicos para os organismos (Sayeed et al. 2003; Marinowic et al. 2012). Estudos demonstram que os piretróides estimulam a produção de espécies reativas de oxigênio e produzem danos oxidativos em componentes celulares essenciais (Marinowic et al. 2012). Sayeed et al. (2003) encontraram efeitos tóxicos em sistemas oxidante/antioxidante após exposição da espécie de peixe Channa punctatus a uma concentração subletal de deltametrina durante 48 hs. Diante dessas evidências, Marinowic et al. (2012) argumentam que uma possível rota que conduziria aos danos observados ao DNA seria a do estresse oxidativo na fisiologia celular, ocasionado pela exposição aos piretróides. Wang et al. (2015) sugerem que o aumento de espécies reativas de oxigênio está associado com o aumento das concentrações subletais de imidacloprid, resultando também em grandes danos ao DNA. Portanto, ambos inseticidas em nosso estudo têm potencial genotóxico, tendo como possível rota dos danos ao DNA o estresse oxidativo. Contudo aqui apenas o inseticida deltametrina apresentou genotoxicidade para abelhas operárias da espécie $M$. quadrisfaciata nas concentrações subletais utilizadas.

As abelhas são importantes para a manutenção e o funcionamento dos ecossistemas (Allen-Wardell et al. 1998), uma vez que 78\% das angiospermas na região temperada e $94 \%$ nas regiões tropicais dependem da polinização realizadas por elas (Ollerton 2011). Além disso, possuem grande relevância econômica em diversos cultivos, pois melhoram qualidade e quantidade de frutos e sementes (Costanza et al.1997; Klein et al. 2007). Dessa forma, algumas medidas poderiam ser implementadas para minimizar os impactos negativos dos inseticidas, como por exemplo, indicação de 
inseticidas de baixo risco feita por especialistas, pulverizações ao entardecer de inseticidas cujo ingrediente ativo se degrade em poucas horas e uso de inseticidas seletivos e do manejo integrado de pragas (Freitas \& Pinheiro 2012). Embora sejam medidas necessárias e tenham havido esforços nesse sentido desde que foi evidenciado o declínio de abelhas em várias partes do mundo (Imperatriz-Fonseca 2010), essas medidas são de difícil implementação, pois os inseticidas muitas vezes são considerados uma solução rápida e fácil para controlar insetos-praga nos cultivos, e por isso utilizados sem o devido cuidado (Reis-Filho et al. 2009).

Baseado nos resultados do presente estudo foi possível verificar que o inseticida deltametrina em baixas concentrações induz danos ao DNA em hemócitos de abelhas da espécie $M$. quadrifasciata, enquanto que para o inseticida imidacloprid não foi possível evidenciar tais danos nas baixas concentrações utilizadas. No entanto, estudos adicionais em muitos aspectos são necessários para uma melhor compreensão da genotoxicidade de ambos inseticidas. Para o inseticida deltametrina são necessários estudos envolvendo concentrações próximas da Dose letal 50 (DL50) para verificar se os danos ao DNA aumentarão à medida que aumentam as concentrações do inseticida. Para o imidacloprid, é necessário encontrar o limiar no qual os danos ao DNA se iniciam e em concentrações próximas da Dose letal 50 (DL50). Para ambos inseticidas seria importante investigar em qual concentração subletal os danos ao DNA podem ser reparados e os efeitos adversos da exposição dos inseticidas por um período de tempo maior. Por último, a espécie Melipona quadrifasciata mostrou-se como um promissor bioindicador para detectar genotoxicantes em ecossistemas agrícolas. 


\section{Referências bibliográficas}

Aizen, M.; Garibaldi, L.; Cunningham, S.; Klein, A. (2008) Long-term global trends in crop yield and production reveal no current pollination shortage but increasing pollinator dependency. Current Biology, 18, 1572 -1575.

Allen-Wardell, G., Bernhardt, P., Bitner, R., Burquez, A., Buchmann, S., Cane, J., Cox, P.A., Dalton, V., Feinsinger, P., Ingram, M., Inouye, D., Jones, C.E., Kennedy, K., Kevan, P., Koopowitz, H., Medellin, R., Medellin-Morales, S., Nabhan, G.P. Pavlik, B., Tepedino, V., Torchio, P., Walker, S. (1998) The potential consequences of pollinator declines on the conservation of biodiversity and stability of food crop yields. Conservation Biology, 12, 8-17.

Aliouane, Y., Adessalam, K., Hassani, A.K., Gary, V., Armengaud, C., Lambin, M., Gauthier, M. (2009) Subchronic exposure of honeybees to sublethal doses of pesticides: effect on behavior. Environmental Toxicology Chemistry, 28,113122.

Azqueta, A., Langie, S., Collins, A., eds. (2015) 30 years of the comet assay: an overview with some new insights. Lausanne: Frontiers Media.

Bauer, D.M., Wing, I.S. (2010) Economic consequences of pollinator declines: A synthesis. Agricultural and Resource Economics Review, 39, 368-383.

Belzunces, L.P., Vandame, R., Xingfa, G.U. (2001) Joint effects of pyrethroid insecticides and azole fungicides on honey-bee thermoregulation. In: Belzunces, L.P., Pelissier, C., Lewis, G.B. (Eds.). Hazard of pesticides to bee. Avignon: INRA, 2001, Paris, 297-298 p. 
Biesmeijer, J.C., Roberts, S.P.M., Reemer, M., Ohlemüller, R., Edwards, M., Peeters, T., Schaffers, A.P., Potts, S.G., Kleukers, R., Thomas, C.D., Settele, J., Kunin, W.E. (2006) Parallel declines in pollinators and insect-pollinated plants in Britain and the Netherlands. Science, 313, 351-354.

Blacquière, T., Smagghe, G., van Gestel, C.A., Mommaerts, V. (2012) Neonicotinoids in bees: a review on concentrations, side-effects and risk assessment. Ecotoxicology, 21, 973-992.

Cooke, M.S., Evans, M.D., Dizdaroglu, M., Lunec, J. (2003) Oxidative DNA damage: mechanisms, mutation, and disease. The Federation of American Societies for Experimental Biology Journal, 17, 1195-1214

Costanza, R., D'Arge, R., Groot, R., Farber, S., Grasso, M., Hannon, B., Limburg, K., Naeem, S., O'neill, R.V., Paruelo, J., Raskin, R.G., Sutton, P., Belt, M. V. D. (1997) The value of the world's ecosystem services and natural capital. Nature, 38, 253-260.

Carvalho, S.M., Carvalho, G.A., Carvalho, C.F., Bueno Filho, J.S.S., Baptista, A.P.M. (2009) Toxicidade de acaricidas/inseticidas empregados na citricultura para a abelha africanizada Apis mellifera L. 1758 (Hymenoptera: Apidae). Arquivos do Instituto Biológico, 76, 597-606.

Camargo, C.A. (1979) Sex determination in Bees. XI Production of diploid males and sex determination in Melipona quadrifasciata. Journal of Apicultural Research, $18,77-84$.

Decourtye, A., Devillers, J., Cluzeau, S., Charreton, M., Pham-Delegue, M.H. (2004) Effects of imidacloprid and deltamethrin on associative learning in honeybees under semi-field and laboratory conditions. Ecotoxicology and Environmental Safety, 57, 410-419. 
Decourtye, A., Devillers, J., Genecque, E, Le Menach, K., Budzinski, H., Cluzeau, S., Pham-Delegue, M.H. (2005) Comparative sublethal toxicity of nine pesticides on olfactory learning performances of the honeybee Apis mellifera. Archives of Environmental Contamination Toxicology, 48, 242-250.

Delaplane, K.S., Mayer, D.F. (2000) Crop pollination by bees. CABI Publishing, New York, $364 \mathrm{p}$.

Del Sarto, M.C.L., Peruquetti, R.C., Campos, L.A.O. (2005) Evaluation of the neotropical bee Melipona quadrifasciata (Hymenoptera: Apidae) as pollinator of greenhouse tomatoes. Journal of Economic Entomology, 98, 260-266.

Desneux, N., Decourtye, A., Delpuech, J.M. (2007) The sublethal effects of pesticides on beneficial arthropods. Annual review of entomology, 52, 81-106.

European Food Safety Authority (2013) Conclusion on the peer review of the pesticide risk assessment for bees for the active substance imidacloprid. EFSA, 11, 1-55.

Food and Agriculture Organization of the United Nations -FAO (2004) Conservation and management of pollinators for sustainable agriculture - The international response. In: Freitas, B.M.; Pereira, J.O.P. (Eds.). Solitary bees; Conservation, rearing and management for pollination. Imprensa Universitária, Fortaleza, 19$25 \mathrm{p}$.

Feng, S., Kong, Z., Wang, X., Zhao, L., Peng, P. (2004) Acute toxicity and genotoxicity of two novel pesticides on amphibian, Rana N. Hallowell. Chemosphere, 56, $457-463$.

Feng, S., Kong, Z., Wang, X., Peng, P., Zeng, E.Y. (2005) Assessing the genotoxicity of imidacloprid and RH-5849 in human peripheral blood lymphocytes in vitro with comet essay and cytogenetics tests. Ecotoxicology and Environmental Safety, 61, 239-246. 
Freitas, B.M., Pinheiro, J.N. (2010) Efeitos sub-letais dos pesticidas agrícolas e seus impactos no manejo de polinizadores dos agroecossistemas brasileiros. Oecologia Australis, 14, 282-298.

Freitas, B.M.; Pinheiro, J.N. (2012) Polinizadores e pesticidas: princípios e manejo para os agroecossistemas brasileiros. MMA, Brasília,112 p.

Frantzios, G., Paptsiki, K., Sidiropoulou, B., Lazaridis, I., Theophilidis, G., MavraganiTsipidou, P. (2008) Evaluation of insecticidal and genotoxic effects of Imidacloprid and Acetochlor in Drosophila Melanogaster. Journal of Applied Entomology, 132, 583-590.

Gallai, N., Salles, J., Settele, J., Vaissiere, B. (2009) Economic valuation of the vulnerability of world agriculture confronted with pollinator decline. Ecological Economics, 68, 810-821.

Giannini, T.C., Cordeiro, G.D., Freitas, B.M., Saraiva, A.M., Imperatriz-Fonseca, V.L. (2015) The Dependence of crops for pollinators and the economic value of pollination in Brazil. Journal of Economic Entomology, 108,849-857.

Goulson D, Nicholls E, Botías C, Rotheray EL (2015) Bee declines driven by combined stress from parasites, pesticides, and lack of flowers. Science 347:6229.

Gregorc, A., Ellis, J. (2011) Cell death in situ in laboratory reared honey bee (Apis mellifera L.) larvae treated with pesticides. Pesticide Biochemistry and Physiology, 99, 200-207.

Gross, M. (2013) EU ban puts spotlight on complex effects of neonicotinoids. Current Biology, 23, R462-R464.

Inglesfield, C. (1989) Pyrethroids and terrestrial non-target organisms. Pesticide Science, 27, 387-428. 
Imperatriz-Fonseca, V.L. (2010) Conservação de polinizadores no ano internacional da Biodiversidade. Oecologia Australis, 14, 14-15.

Instituto Nacional do Meio Ambiente e Recursos Naturais Renováveis (2012) Exigências para a revalidação do ingrediente ativo Imidacloprid. Ofício Circular No. 05/12/CGASQ/DIQUA, Brasília, DF, Brasil.

Jay, S.C. (1986) Spatial management of honeybees on crops. Annual Reviews of Entomology, 31, 49-65.

Jha, A.N. (2008) Ecotoxicological applications and significance of the comet assay. Mutagenesis, 23, 207-221.

Johnson, R.M., Ellis, M.D., Mullin, C.A., Frazier, M., Johnson, R.M., Ellis, M.D., Mullin, C.A., Frazier, M. (2010) Pesticides and honey bee toxicity - USA. Apidologie, 41, 312-331.

Kevan, P.G., Imperatriz-Fonseca, V.L. (2006) Pollinating bee: The conservation link between agriculture and nature. Bárbara Bela Editora, Brasília, 336 p.

Klein, A.M., Vaissière, B.E., Cane, J.H., Steffan-Dewenter, I., Cunningham, S.A., Kremen, C., Tscharntke, T. (2007) Importance of pollinators in changing landscapes for world crops. Proceedings. Biological sciences / The Royal Society, 274, 303-13.

Latorraca, A., Marques, G.J.G., Sousa, K.V., Fornes, N.S. (2008) Agrotóxicos utilizados na produção de tomate em Goiânia e Goianápolis e efeitos na saúde humana. Comunicação em Ciências da Saúde, 19, 365-374.

Lapuente, J., Lourenço, J., Mendo, S.A., Borràs, M., Martins, M.G., Costa, P.M., Pacheco, M. (2015) The comet assay and its applications in the field of ecotoxicology: a mature tool that continues to expand its perspectives. Frontiers in genetics, 6, 21-40. 
Liu, W., Zhu, L., Wang, J., Wang, J.H., Xie, H., Song, Y. (2009) Assessment of the genotoxicity of endosulfan in earthworm and white clover plants using the comet assay. Archives of Environmental Contamination and Toxicology, 56,742-746.

MAPA (2015) Ministério da Agricultura Pecuária e Abastecimento. Agrofit, Sistemas de Agrotóxicos Fitossanitário. Disponível em: <http://agrofit.agricultura.gov.br/ agrofit-cons/principal-agrofit-cons >. Acesso em: 30 de outubro de 2015.

Marinowic, D.R., Mergener, M., Pollo, T.A., Maluf, S.W., Silva, L.B. (2012) In vivo genotoxicity of the pyrethroid pesticide $\beta$-cyfluthrin using the comet assay in the fish Bryconamericus iheringii. Zeitschrift fur Naturforschung, 67, 308-311.

Menten, J.O. (2009) Liderança em tecnologia fitossanitária. Revista AgroAnalysis, 29, $39-40$.

Michener, C.D. (1979) Biogeography of the bees. Annals of the Missouri Botanical Garden, 66, 277-347.

Michener, C.D (2007) The bees of the world. Johns Hopkins University Press; Baltimore, MD, $953 \mathrm{p}$.

Mullin, C.A., Frazier, M., Frazier, J.L., Ashcraft, S., Simonds, R., vanEngelsdorp, D., Pettis, J.S. (2010) High levels of miticides and agrochemicals in North American apiaries: Implications for honey bee health. PLoS ONE, 5, e9754.

Nation, J.L., Robinson, F.A., Yu, S.J., Bolten, A.B. (1986) Influence upon honeybees of chronic exposure to very low levels of selected insecticides in their diet. Journal of Apicultural Research, 25, 170-177. 
Nocelli, R.C.F., Malaspina, O., Carvalho, S.M., Lourenço, C.T., Roat, T.C., Pereira, A.M., Silva-Zacarin, E.C.M. (2012) Abelhas e os defensivos agrícolas. In: Imperatriz-Fonseca, V.L., Canhos, D., Alves, D.A., Saraiva, A.M. (org) Polinizadores no Brasil: contribuição e perspectivas para biodiversidade, uso sustentável, conservação e serviços ambientais. São Paulo, EDUSP, 285-300 p.

Nunes-Silva, P., Hrncir, M., Imperatriz-Fonseca, V.L. (2010) A polinização por vibração. Oecologia Australis, 14, 140-151.

Ollerton, J., Winfree, R., Tarrant, S. (2011) How many flowering plants are pollinated by animals? Oikos, 120, 321-326.

Olive, P.L., Banath, J.P., Durand, R.E. (1990) Heterogeneity in radiation-induced DNA damage and repair in tumor and normal cells measured using the 'comet' assay. Radiation Research, 122, 86-94.

Pavlica M, Klobuèar, G.I.V., Moja, N., Erben, R., Pape, D. (2001) Detection of DNA damage in haemocytes of zebra mussel using comet assay. Mutation Research, 490, 209-214.

Potts, S.G., Biesmeijer, J.C., Kremen, C., Neumann, P., Schweiger, O., Kunin, W.E. (2010) Global pollinator declines: trends, impacts and drivers. Trends in Ecology \& Evolution, 25, 345-53.

Reis-Filho, J.S., Marin, O.B., Fernandes, P.M. (2009) Os agrotóxicos na produção de tomate de mesa na região de Goianápolis, Goiás. Pesquisa Agropecuária Tropical, 39, 307-316.

Santos, S. B., Roselino, A.C., Hrncir, M., Bego, L.R. (2009) Pollination of tomatoes by the stingless bee Melipona quadrifasciata and the honey bee Apis mellifera (Hymenoptera, Apidae). Genetics and Molecular Research, 8, 751-757. 
Sayeed, I., Parvez, S., Pandey, S., Bin-Hafeez, B., Haque, R. \& Raisuddin, S. (2003). Oxidative stress biomarkers of exposure to deltamethrin in freshwater fish, Channa punctatus bloch. Ecotoxicology and Environmental Safety, 56, 295301.

Schmuck, R., Schoning, R., Stork, A., Schramel, O. (2001) Risk posed to honeybees (Apis melifera L., Hymenoptera) by an imidacloprid seed dressing of sunflowers. Pest Management Science, 57, 225-238.

Schneider, C.W., Tautz, J., Grünewald, B., Fuchs, S. (2012) RFID tracking of sublethal effects of two neonicotinoid inseticides on the foranging behavior of Apis mellifera. Plos One, 7, e30023.

Skerl, M.I.S., Gregorc, A. (2010) Heat shock proteins and cell death in situ localization in hypopharyngeal glands of honeybee (Apis mellifera carnica) workers after imidacloprid or coumaphos treatment. Apidologie, 41, 73-86.

Steinert, S.A., (1999) DNA damage as bivalve biomarker and as an environmental assessment tool. Biomarkers, 4, 492-496.

Stevenson, J.H. (1978) The acute toxicity of unformulated pesticides to worker honey bees ( Apis mellifera L.). Plant Pathology, 27, 38 - 40.

Thomazoni, D., Soria, M.F., Kodama, C., Carbonari, V., Fortunato, R.P., Degrande, P.E, Valter, V.A. (2009) Selectivity of insecticides for adult workers of Apis mellifera (Hymenoptera: Apidae). Revista Colombiana de Entomologia, 35, $173-176$.

Thompson, H.M. (2002) Behavioral effects of pesticides in bees - their potential for use in risk assessment. Ecotoxicology, 12, 317-330. 
Tomé, H.V.V., Martins, G.F., Lima, M.A.P., Campos, L.A.O., Guedes, R.N.C. (2012) Imidacloprid-induced impairment of mushroom bodies and behavior of the native stingless bee Melipona quadrifasciata anthidioides. PLoS ONE, 7, e38406.

Vandame, R., Meled, M., Colin, M.E., Belzunces, L.P. (1995) Alteration of the homingflight in the honey bee Apis mellifera L. exposed to sublethal dose of Deltamethrin. Environmental Toxicology Chemistry, 14, 855-860.

VanEngelsdorp, D., Meixner, M.D. (2010) A historical review of managed honey bee populations in Europe and the United States and the factors that may affect them. Journal of Invertebrate Pathology, 103, S80-S95.

Whitehorn, P.R., O'Connor, S., Wackers, F.L., Goulson, D. (2012) Neonicotinoid pesticide reduces bumble bee colony growth and queen production. Science, $\mathbf{3 3 6}$, $351-352$.

Zang, Y., Zhong, Y., Luo, Y., Kong, Z. M. (2000) Genotoxicity of two novel pesticides for the earthworm, Eisenia fetida. Environmental Pollution, 108, 271-278.

Wang, K., Qi, S., Mu, X., Chai, T., Yang, Y., Wang, D., Li, D., Che, W., Wang, C., (2015) Evaluation of the toxicity, AChE activity and DNA damage caused by imidacloprid on earthworms, Eisenia fetida. Bulletin of Environmental Contamination and Toxicology, 95, 475-480. 
Capítulo III

Climate change threatens pollination services in tomato crops in Brazil 
Manuscript submitted to the Journal: Agriculture, Ecosystems \& Environment

\section{Climate change threatens pollination services in tomato crops in Brazil}

Marcos A. S. Elias ${ }^{1}$; Fabio J. A. Borges ${ }^{2}$; Leonardo L. Bergamini ${ }^{2}$, Edivani V. Franceschinelli $^{3}$; Edison R. Sujii ${ }^{4 *}$

${ }^{1}$ Programa de Pós-Graduação em Ecologia. Universidade de Brasília (UNB), 70910-900 Brasilia, DF, Brasil.

${ }^{2}$ Programa de Pós-Graduação em Ecologia e Evolução. Universidade Federal de Goiás (UFG),74690-900, Goiânia, GO, Brasil.

${ }^{3}$ Departamento de Botânica, Instituto de Ciências Biológicas. Universidade Federal de Goiás (UFG), 74690-900, Goiânia, GO, Brasil.

${ }^{4}$ Embrapa Recursos Genéticos e Biotecnologia - Av. W5 Norte (final) Caixa Postal 02372 - Brasília, DF, Brasil, 70770-917. Fax: +55 61 34484673, email:edison.sujii@embrapa.br

* Corresponding author 


\section{Mudanças climáticas ameaçam o serviço de polinização em cultivos de tomate no}

\section{Brasil}

\section{Resumo}

Mudanças climáticas são uma das principais ameaças a biodiversidade no século 21. Entender como as mudanças climáticas podem afetar a distribuição das espécies ajuda a simular como os serviços ecossistêmicos poderiam ser prejudicados devido a potencial ausência de polinizadores nos cultivos no futuro. O objetivo desse estudo foi avaliar as potenciais consequências das mudanças climáticas na distribuição geográfica de cinco espécies de abelhas nativas e estimar os possíveis efeitos das alterações nas distribuições dessas espécies na área plantada de tomateiro no Brasil. As condições climáticas foram projetadas para o ano de 2100 em dois cenários de emissão de carbono: cenário otimista e cenário pessimista. Projeções conjuntas foram implementadas para simular alterações na distribuição das cinco espécies de abelhas através de cinco algoritmos. A área total do cultivo foi computada em células com ao menos $50 \%$ de adequabilidade para cada espécie e para cada cenário climático. Os resultados mostram uma redução da área total de adequabilidade de habitat para as cinco espécies em ambos os cenários, sendo mais intensa no cenário pessimista. A espécie que apresentou maior redução na sua área total de adequabilidade de habitat foi Bombus morio, ficando restrita a algumas partes das regiões Sudeste e Sul do Brasil. Em relação aos cultivos de tomate, em ambos os cenários, também haverá uma redução na concordância entre a área plantada de tomate no Brasil e área total de adequabilidade de habitat para todas as espécies. Outra vez, a espécie que sofreu maior redução na concordância foi B. morio, com uma redução de 39,8 \% no cenário otimista e de $63,8 \%$ no pessimista. Esse estudo indica que as mudanças climáticas previstas podem causar 
redução na distribuição geográfica dessas espécies em 2100 com implicações para conservação e a economia das regiões produtoras de tomate.

Palavras-chave: modelos de distribuição de espécies, polinizadores, biodiversidade.

\begin{abstract}
Understanding how climate change may affect species distribution helps predict how ecosystem services, such as pollination, could be impaired in the future. Here, we examine the potential consequences of climate change on the geographical distribution of five native bee species and estimate the possible effects of bee distribution shifts on tomato crops in Brazil. Ensemble forecasting was implemented through five algorithms in two carbon emission scenarios to predict range shifts for five tomato-visiting bee species for the year 2100 . We then calculated the total tomato crop area in the cells with at least $50 \%$ bee suitability, for each bee species, in each scenario. Results showed that all species will undergo a reduction in suitable areas in both scenarios. The high agreement between tomato crops and bee distribution observed in the present will also be reduced in both scenarios for all species, especially in the pessimistic scenario. The species Bombus morio had the highest reduction in range due to habitat suitability, being restricted to some parts of southeastern and southern Brazil. Over $60 \%$ of the tomato crop area presently occurring within the distribution of $B$. morio will become climatically unsuitable in the pessimistic emission scenario. This study indicates that the predicted climate change may negatively impact several species associated with tomato crops in Brazil by the year 2100. This is troubling, as it could result in tomato production losses, bringing economic and environmental losses to the tomato-producing regions with implications for pollinator conservation.
\end{abstract}


Keywords: Solanum lycopersicum, pollinator, modeling, ecosystem services, species conservation.

\section{Introduction}

Climate change is among the greatest biodiversity threats of the 21 st century (Araújo et al. 2004; Brook et al. 2008; Leadley et al. 2010; Kerr et al. 2015). The impacts of global change may vary among species, changing their phenology (Root et al. 2003), geographical distribution (Araújo et al. 2004), and possibly causing the extinction of several species (Pounds et al. 2006). One of the main effects of climate change is the reduction in the availability of suitable habitat (Giannini et al. 2013), leading to reductions or shifts in range (Kuhlmann et al. 2012; Kerr et al. 2015). The extent of these effects is alarming, with estimates that $57 \%$ of all plants and $34 \%$ of all animals will have about $50 \%$ of their geographical distributions displaced by the year 2100 (Warren et al. 2013). Furthermore, climate change effects may decrease the efficiency of protected areas, as such areas may become climatically inadequate in the future (Ferro et al. 2014; Martins et al. 2015).

Climate change may cause temporal and spatial mismatches between plants and their pollinators due to changes in their phenology and geographic ranges, in addition to the direct effects on the species (Memmott et al. 2007; Hegland et al. 2009; Polce et al. 2014; Kerr et al. 2015). Pollinators are extremely important in the maintenance of global biodiversity, for providing a vital ecosystem service for natural systems and agriculture (Daily 1997). A total of $78 \%$ of the plant species known in temperate zones and $94 \%$ of tropical plant communities are pollinated by animals (Ollerton et al. 2011). Insects, especially bees, are involved in the pollination of $75 \%$ of all cultivated species, 
which are highly important in the global human food supply (Klein et al. 2007). Additionally, pollinators increase the quality and amount of fruits and seeds of different cultivars in the world (Klein et al. 2007). One third of agricultural production depends on animal pollination services (Kremen et al. 2007; Klatt et al. 2014).

The animal-pollination of cultivated and wild plants is one of the ecosystem services currently at risk due to rapid and increasing anthropogenic changes (SteffanDewenter et al. 2005; Biesmeijer et al. 2006; Aizen and Harder 2009; Potts et al. 2010; Goulson et al. 2015). The main threat to native pollinators in developed countries is intensive agriculture, whereas in developing countries, deforestation and destruction of natural areas are cited as the main threats (Aizen et al. 2008). The use of pesticides, introduction of exotic species, environmental pollution, and the occurrence of diseases and parasites in managed pollinators are other equally important factors (Kevan and Imperatriz-Fonseca 2006). However, the decline in pollination services in agriculture due to global changes has not been properly evaluated (Gallai et al. 2009).

Bees are the main pollinators of angiosperms, and are responsible for about $35 \%$ of global food production, increasing the production of coffee, canola, soybean, orange, apple, passion-fruit, tomato, and others (Klein et al. 2003; Kremen et al. 2007; Klatt et al. 2014). A considerable increase in the production of fruits and seeds after pollination by native or introduced bees was observed in these crops (Veddeler et al. 2008). Recent studies have shown a $55.2 \%$ increase in the productivity of pollinated canola plants (Durán et al. 2010; Rosa et al. 2011). Studies showed an increase of up to $200 \%$ in coffee fruit yield after bee pollination (De Marco and Coelho 2004; Ricketts et al. 2008), and $65 \%$ in the production of tomato fruits when bees visit tomato flowers (Melo-Silva et al. 2013). 
Brazil occupies the ninth place in world production of tomato and is the largest producer in Latin America. Brazilian annual production is estimated in 4.4 million tons (FAO 2013). The Brazilian Institute of Geography and Statistics (IBGE) estimated that tomato production in Brazil profited R $\$ 6.6$ billion (US\$ 2 billion) in 2011. Most of this production is concentrated in the states of Goiás, São Paulo, Minas Gerais, Paraná and Bahia (Brito and Melo 2010). Flowers of cultivated tomato varieties can be selfpollinated because their stigmas are shorter than the stamens and are located within the anther pollen tube. The pollen is released from flower anthers through a pore opening located in the distal part of the anthers. This kind of anther opening makes it essential for the pollinator to vibrate the anthers for pollen grain release. This behavior increases the pollen load on the stigma, and fruit and seed production (Greenleaf and Kremen 2006; Melo-Silva et al. 2013). Therefore, only bees able to perform buzz pollination (vibration process) are regular pollinators of tomato flowers, because pollen grain release from the poricidal anthers requires bee vibration (Fontes and Silva 2002). A recent study showed that global warming may change the geographical distribution of Xylocopa frontalis, an uncommon tomato visitor (Giannini et al. 2013). However, no study has predicted changes in the geographical distribution of the main tomato pollinators due to global warming.

In this study, we aim to examine the potential consequences of climate change on the geographical distribution of five native bee species, known to be among the most frequent pollinators of tomato crops in Brazil. Furthermore, we aim to estimate the possible effects of bee distribution shifts on tomato production by relating bee suitability and total crop area in each cell. 


\section{Methods}

\section{Biotic data}

We analyzed four Apidae and one Halictidae bee species, namely Exomalopsis analis Spinola, 1853, Bombus morio (Swederus, 1787), Eulaema nigrita Lepeletier, 1841, Centris tarsata Smith, 1874 and Augochloropsis callichroa (Cockerell, 1900). These five species were among the most abundant bees from the 26 bee species that were observed visiting tomato flowers in conventional tomato plantations in the state of Goiás, Brazil (Edivani Franceschinelli pers. comm.). Besides, some of these bees are also among the most common pollinators of tomato crops located in other Brazilian States, such as Sergipe (Santos and Nascimento 2011) and Minas Gerais (Santos et al. 2014). These five species represent well the diversity of bees visiting tomato flowers, comprising small (A. callichroa, Ex. analis) and large bees (B. morio, Eu. nigrita) and bees with different levels of sociality (Exomalopsis analis is para-social, Bombus morio is social and the other three are solitary bees).

Occurrence points of each species were compiled using different data sources, especially Internet data providers (Global Information Biodiversity Facility, SpeciesLink), literature and field data. The details of the data sources can be found in the Online Resource 1.

\section{Climate data}

Climate data were used to determine a model of the current range of five native bee species using the Ecoclimate database (ecoclimate.org; Lima-Ribeiro et al. 2015). We used five bioclimatic variables (i.e., annual mean temperature, mean diurnal range, temperature seasonality, precipitation of driest month, and precipitation of wettest quarter). These variables were selected among the variables with the highest loadings in 
the first five Varimax rotated eigenvectors of the correlation matrix between all variables (Terribile et al. 2012). This procedure avoids collinearity problems when building species distribution models (SDMs).

For future climate predictions, we used the same five layers projected onto the year 2100 , mean of the simulations for $2080-2100$. The projections were also provided by Ecoclimate. Two carbon emission scenarios were applied, one with a more optimistic, Representative Concentration Pathways (RCP) 2.6, and a more pessimistic (RCP 8.5) carbon emission rate for 2100 (see details in Taylor 2009; Taylor et al. 2012).

\section{Modelling distribution}

We used an ensemble model implemented in the BIOMOD2 package (Thuiller et al. 2009) in R 3.1.3 (R Development Core Team 2015) to model species distribution, using only the available presence data. Pseudo-absences were generated randomly at any point located at least two degrees in latitude or longitude from any presence point (Barbet-Massin et al. 2012) over the whole study area. We aim to obtain more accurate predictions of the future range of the species using an ensemble forecasting approach (Grenouillet et al. 2011). Ensemble forecasting was implemented through five algorithms: random forest (RF), flexible discriminant analysis (FDA), generalized linear models (GLM), classification tree analysis (CTA) and Maximum Entropy (MAXENT). We used a random subset of $70 \%$ of the data to calibrate the model and the remaining $30 \%$ to evaluate its predictive performance. We used the area under the receiver operating characteristic (ROC) curve (AUC) (Fielding and Bell 1992) and the true skill statistic (TSS) to evaluate model performance (Allouche et al. 2006). The AUC values range from 0.5 (models with random predictions) to 1 (perfect model fit), while the TSS values from 0 (random model) to 1 (model with an excellent agreement). The data 
splitting approach was replicated 30 times to obtain the average AUC and TSS values by cross validation. Only models with TSS values above 0.7 were retained for the ensemble forecasts, which were then obtained by calculating the average suitability values while weighting models by their TSS values.

\section{Shifts in suitable habitat area}

Suitable habitat area was computed for each species in two steps for both the present ensemble models and for the two future scenarios. First, grid cells with less than $50 \%$ suitability in the ensemble forecasts were considered unsuitable. The area of the remaining cells was then added, and the suitability value for the cell used as a weighting factor. Hence, a cell with $90 \%$ suitability was considered as having $90 \%$ of its area comprising suitable habitats. Proportional changes in suitable habitat areas of the future scenarios in comparison with the present forecast were computed. The uncertainty of these estimates arising from the differences in the models used for the ensemble forecast was estimated by computing the proportional changes, using the $2.5 \%$ and the $97.5 \%$ quantiles for the suitability values resultant of all models for each cell.

\section{Bee suitability and tomato crops}

We obtained data for the area of tomato crop for 2008 to 2013 for all Brazilian municipalities (http://www.sidra.ibge.gov.br/bda/tabela/listabl.asp?z=t\&o=1\&i=P\&e= $1 \& \mathrm{c}=492)$. We transposed the data to the cell scale by sampling, since the only data available was at the municipality scale. First, we estimated the average tomato crop density in each municipality by dividing the average area planted with tomato in the five-year period by the municipality area, and used a sampling grid of points evenly spread every $0.04^{\circ}$ to obtain tomato density values from the underlying municipalities. 
The total crop area in each cell was estimated by multiplying the mean of the density values within the cell by the cell area. Finally, we computed the total crop area in the cells with at least $50 \%$ bee suitability habitat, for each bee species and for each climatic scenario (present, optimistic and pessimistic future) as a measure of agreement between crop distribution and bee occurrences. Estimated changes in tomato/bee agreement were calculated under a scenario where tomato crops retain their present distribution and thus represent the expected changes resulting only from bee distribution shifts.

\section{Results}

A total of 764 occurrence points were obtained from different sources (see Online Resource 1 for details). The ensemble models obtained for all species had AUC and TSS values equal to or greater than 0.9 , and can be considered accurate. Furthermore, the TSS and AUC values from ensemble forecasting were higher than the values of each of the five distribution models of individual species (single-SDMs). The RF model, among the single-SDMs, showed the highest TSS and AUC values. (Details of all species models and their values of AUC and ROC and single-SDM can be found in Online Resource 2).

According to our results, all species will undergo a reduction in suitable occurrence areas in the future, in both scenarios (Fig. 1). The species B. morio had the greatest area reduction under the optimistic ( $\mathrm{RCP} 2.6)$ and pessimistic scenarios (RCP 8.5): near $38(\%)$ and $71(\%)$ in 2100 , respectively. The second species exhibiting a relatively high impact is $A$. callichroa: near $32(\%)$ and $70(\%)$ in 2100 , respectively. There were, however, differences in the degree of uncertainty between the species, as Eu. nigrita, Ex. analis and B. morio exhibited a lower uncertainty in the estimates than the other species (Fig. 1). 
Ensemble projections with average weighting indicated that all species, in the optimistic scenario, had a greater reduction of appropriate areas in the central part of Brazil. Five species showed a reduction of suitable area in the Midwest, Southeast and Northeast regions (Fig. 2). The reduction for Eu. nigrita and C. tarsata was more extensive in the south of the geographical distribution, with only Eu. nigrita and $B$. morio increasing their suitable occurrence areas: the former in the southeast region, state of Minas Gerais, and the latter in the southern region, state of Santa Catarina. The pessimistic scenario showed a reduction in the central part of the country that spanned toward the coast of Brazil (Fig. 2). There were retractions in suitable occurrence areas for all species in the southeastern region, particularly in the state of Minas Gerais and in the coastal region.

Assuming that tomato crop locations will not change in the future, there will be a sharp reduction in total crop area present in cells of at least $50 \%$ habitat suitability for the five species of pollinators in both scenarios for these plantation areas (Table 1). However, in the worst-case scenario this reduction will be higher. For example, the species that underwent the greatest reduction was, again, B. morio, with a $49.5 \%$ reduction in agreement in the optimistic and $78.8 \%$ in the pessimistic scenario.

\section{Discussion}

In this study, we found that the five most common species of bees in tomato pollination on average showed a considerable loss of climatically suitable habitat within their range for the year 2100. Additionally, we found that the high agreement between tomato crop area and bee suitability observed in this study will be severely reduced in the future. Both results suggest that the tomato pollination service may be threatened in the future, confirming the troubling scenario that has been demonstrated by other 
studies in North America (Rader et al. 2013), Europe (Polce et al. 2014), Africa (Kuhlmann et al. 2012) and also in South America (Giannini et al. 2012; Giannini et al. 2013; Martins et al. 2015).

The tomato is of great economic importance for Brazil. A recent study showed that the crop production value in Brazil is about $\$ 1.5$ billion and that the economic value of the pollination service for tomato in Brazil is approximately $\$ 1$ billion annually (the ratio of dependence of pollination of this crop is 0.65 , where 0 is no dependency and 1 is maximum dependence) (Giannini et al. 2015). Here, considering these values in both scenarios, the future the losses would be significant because potential occurrence areas for five native bee species will be more restricted to a small part of the southeast region and the coastal region, which correspond to only $20 \%$ of national production (Brito and Melo 2010). Tomato crops in the states of the southeast and Midwest regions would suffer most in the absence of pollination service, for example, the states of Goiás, Minas Gerais and São Paulo, which together are responsible for $61 \%$ of national production of tomato (Brito and Melo 2010). Besides, at least two more consequences could be mentioned regarding the loss of pollinators in the crops. First, some of these tomato crops are cultivated regionally, and the loss of native pollinators can have a potentially high impact on local economies, for example, on the municipality of Goianápolis, state of Goiás. Second, other crops may lose the pollination service carried out by these species, such as other cultivated plants species of the genus Solanum (Roubik 1995; Imperatriz-Fonseca 2004).

The intensity of the predicted response to climate change varied among species. The species Bombus morio has a more southern distribution, and showed a strong reduction in suitable areas, in addition to a high mismatch with tomato crops in the future scenarios. The genus Bombus is known to be more diverse and abundant in colder 
regions (Goulson 2003) and another Neotropical species was also predicted to be severely affected by climate change (Martins et al. 2015). In contrast, Exomalopsis analis, the most abundant bee in tomato crops in the state of Goiás (Edivani Franceschinelli, pers. comm.) was less impacted. This species has a large part of its current distribution in hot, dry areas of Caatinga vegetation in northeastern Brazil, and most of the expected reduction in its abundance in the future will be in this region. Apparently, this species will still be able to withstand future climate conditions in regions that produce tomatoes, in the center-south of the country, when compared to other species. Similar results were found for Centris sponsa, which also occurs in this region (Giannini et al. 2012).

The species Ex. analis is probably very important for the pollination service, since it is abundant in tomato crops (Kleijn et al. 2015), accounting for over $70 \%$ of visits to flowers (Elias 2016.). Our results show that its importance should remain in future scenarios, as Ex. analis underwent the smallest reduction in suitable habitat area and has the smallest discrepancy between the distribution estimated for the future and the area planted with tomatoes today. This implies that the negative effects of climate change on pollination in tomato crops would be minimized. However, the changes expected here also mean an increasing dependency on this species, which is of concern as other threats such as habitat loss, pesticides and pathogens that impact this species can lead to serious impacts on the productivity of crops such as tomato (Potts et al. 2010). Therefore, studies on the biology of Exomalopsis species will be increasingly important in the future to develop conservation and management strategies.

In addition to the impacts on the tomato crops, the loss of native pollinators on crops due to the shift of potential occurrence area could lead to spatial mismatches between pollinators and wild plants (Hegland et al. 2009). As our model focuses on the 
potential distribution of pollinator species associated with tomato crops, our approach does not incorporate the activities of the insect pollinators not connected with tomato flowers. However, our results showed mostly reductions in the central region of Brazil, and in the southeast and northeast regions in the future, in both scenarios. There was also a contraction in suitability values in the coastal region for most species. Wild plants in these regions may undergo a decrease in number of visits and pollen deposition, leading to reduced reproductive success and potential negative effects on population dynamics (Hegland et al. 2009). On the other hand, Eu. nigrita and C. tarsata showed a punctual increase in potential occurrence areas in some regions. This result is in agreement with a recent study that also predicted range expansions for Eu. nigrita (Silva et al. 2015). Nevertheless, even for these species, the potential lack of suitable food plants in the new range can be a limiting factor in the future.

Some actions can help protect the important pollination services for the production of tomato crops to mitigate the potential effects of climate change. For example, to manage areas placing forage plant species near crops (Vaughan and Hoffmann Black 2006), furnishing nest sites for bees (Isaacs and Tuell 2007) and maintaining native vegetation, once fragmentation and habitat loss are major threats to pollinators as well. Alternatively, other possibilities to be considered, though it requires high investments, is either to install beehives of Meliponna quadrifasciata to supply insect-pollinated crops or to plant new crop varieties that are less dependent on pollination.

Here we assess the possible impacts of bee range shifts on tomato crop pollination by assuming that crop area will remain similar in the future scenarios. This was done due to difficulties in predicting changes in crop areas based on climatic variables alone, since many other socio-economic factors play important roles in crop 
distribution (Rounsevell et al. 2005). Nevertheless, our scenarios give an overview of the possible impacts caused by climate change via effects on the pollinators alone, providing a baseline to be compared in future studies with results that also consider the direct effects of climate change on the tomato crops.

This study indicates that the predicted climate change may cause a reduction in the geographical distribution of all the species considered in this study, associated with tomato crops in Brazil by 2100 . This is troubling, as it would result in losses in seed quality and quantity, and on fruit set, bringing economic and environmental damage to the tomato producing regions and implications for pollinator conservation, since climate change can lead to pollinator extinction (Ferro et al. 2014). In addition, the reduction in the potential distribution in the future suggests the need to seek alternatives that minimize losses of the pollination service, improving pollinator habitat and tomato crop management.

\section{Acknowledgments}

We are thankful to B.A.R. Bergamini for the help with the figures. Marcos A. S. Elias was supported by a CNPq grant, and Leonardo L. Bergamini by a CAPES grant.

\section{References}

Aizen MA, Garibaldi LA, Cunningham SA, Klein AM (2008) Long-term global trends in crop yield and production reveal no current pollination shortage but increasing pollinator dependency. Curr Biol 18:1572 -1575

Aizen MA, Harder LD (2009) The global stock of domesticated honey bees is growing slower than agricultural demand for pollination. Curr Biol 19:915-918 
Allouche O, Tsoar A, Kadmon R (2006) Assessing the accuracy of species distribution models: prevalence, kappa and the true skill statistic (TSS). J Appl Ecol $43: 1223-1232$

Araújo MB, Cabeza M, Thuiller W, Hannah L, Williams PH (2004) Would climate change drive species out of reserves? An Assessment of Existing ReserveSelection Methods. Glob Change Biol 10:1618-1626

Barbet-Massin M, Jiguet F, Albert CH, Thuiller W (2012) Selecting pseudo-absences for species distribution models: How, where and how many? Methods Ecol Evol $3: 327-338$

Biesmeijer JC, Roberts SPM, Reemer M, Ohlemüller R, Edwards M, Peeters T, Schaffers AP, Potts SG, Kleukers R, Thomas CD, Settele J, Kunin WE (2006) Parallel declines in pollinators and insect-pollinated plants in Britain and the Netherlands. Science 313:351-354

Brito L, Melo L (2010) A produção mundial e brasileira de tomate. DIEESE- Goiânia: DIEESE - Departamento Intersindical de Estatística e Estudos Socioeconômicos. http://www.dieese.org.br/projetos/informalidade/estudo SobreAproducaoDeTomateIndustrialNoBrasil.pdf. Acessed 23 October 2014

Brook BW, Sodhi NS, Bradshaw CJA (2008) Synergies among extinction drivers under global change. Trends Ecol Evol 23:453-460

Daily G (1997) Nature's services: societal dependence on natural ecosystems. Island Press, Washington, DC

De Marco Jr P, Coelho FM (2004) Services performed by the ecosystem: Forest remnants influence agricultural cultures pollination and production. Biodivers Conserv 13:1245-1255

Durán XA, Ulloa RB, Carrillo JA, Contreras JL, Bastidas MT (2010) Evaluation of 
yield component traits of honey bee pollinated (Apis mellifera L.) rapeseed canola (Brassica napus L.). Chil J Agr Res 70:309-314

FAO (2013) FAOSTAT. Food and Agriculture Organization of the United Nations. http://faostat3.fao.org. Accessed 23 June 2013

Ferro VG, Lemes P, Melo AS, Loyola R (2014) The reduced effectiveness of protected areas under climate change threatens atlantic forest tiger moths. Plos One 9:e107792. doi:10.1371/journal.pone.0107792

Fielding AH, Bell JF (1992) A review of methods for the assessment of prediction errors in conservation presence / absence models. Environ Conserv 24:38-49

Fontes P, Silva D (2002) Produção de tomate de mesa. Aprenda Fácil Editora, Viçosa MG, Brazil.

Gallai N, Salles JM, Settele J, Vaissière BE (2009) Economic valuation of the vulnerability of world agriculture confronted with pollinator decline. Ecol Econ $68: 810-821$

Giannini TC, Acosta AL, Garófalo CA, Saraiva AM, Alves-dos-Santos I, ImperatrizFonseca VL (2012) Pollination services at risk: Bee habitats will decrease owing to climate change in Brazil. Ecol Model 244:127-131

Giannini TC, Acosta AL, Silva CI, Oliveira PEAM, Imperatriz-Fonseca VL Saraiva AM (2013) Identifying the areas to preserve passion fruit pollination service in brazilian tropical savannas under climate change. Agr Ecosyst Environ 171:3946

Giannini TC, Cordeiro GD, Freitas BM, Saraiva AM, Imperatriz-Fonseca VL (2015) The Dependence of crops for pollinators and the economic value of pollination in Brazil. J Econ Entomol 108:849-857

Goulson D (2003) Bumblebees: behavior and ecology. Oxford University Press, |Oxford 
Goulson D, Nicholls E, Botías C, Rotheray EL (2015) Bee declines driven by combined stress from parasites, pesticides, and lack of flowers. Science 347:6229

Greenleaf SS, Kremen C (2006) Wild bee species increase tomato production and respond differently to surrounding land use in Northern California. Biol Conserv $133: 81-87$

Grenouillet G, Buisson L, Casajus N, Lek S (2011) Ensemble modelling of species distribution: the effects of geographical and environmental ranges. Ecography $34: 9-17$

Hegland SJ, Nielsen A, Lázaro A, Bjerknes AL, Totland Ø (2009) How does climate warming affect plant-pollinator interactions? Ecol Lett 12:184-195

Imperatriz-Fonseca VL (2004) Serviços aos Ecossistemas, com ênfase nos polinizadores e polinização. http://www.ib.usp.br/vinces/logo/servicos\%20aos\% 20ecossistemas_polinizadores_vera.pdf. Accessed 28 August 2015

Isaacs R, Tuell J (2007) Conserving native bees on farmland. Michigan State University Extension Bulletin e-2985

Kerr JT, Pindar A, Galpern P, Packer L, Potts SG, Roberts SM, Rasmont P, Schweiger O, Colla SR, Richardson LL, Wagner DL, Gall LF, Sikes DS, Pantonja A (2015) Climate change impacts on bumblebees converge across continents. Science 349:177-180

Kevan PG, Imperatriz-Fonseca VL (2006) Pollinating bee: The conservation link between agriculture and nature. Bárbara Bela Editora, Brasília DF, Brazil.

Klatt BK, Holzschuh A, Westphal C, Clough Y, Smit I, Pawelzik E, Tscharntke T (2014) Bee pollination improves crop quality, shelf life and commercial value. Proc R Soc B 281:20132440. doi:10.1098/rspb.2013.2440 
Kleijn D, Winfree R, Bartomeus I, Carvalheiro LG, Henry M, Isaacs R, et al (2015) Delivery of crop pollination services is an insufficient argument for wild pollinator conservation. Nature Commun 6:7414. doi:10.1038/ncomms8414 (2015)

Klein A-M, Steffan-Dewenter I, Tscharntke T (2003) Fruit set of highland coffee increases with the diversity of pollinating bees. Proc R Soc Lond B 270:955-961

Klein A-M, Vaissière BE, Cane JH, Steffan-Dewenter I, Cunningham SA, Kremen C, Tscharntke T (2007) Importance of pollinators in changing landscapes for world crops. Proc R Soc B 274:303-313. doi:10.1098/rspb.2006.3721

Kremen C, Williams NM, Aizen MA, Gemmill-Herren B, LeBuhn G, Minckley R, Packer L, Potts SG, Roulston T, Steffan-Dewenter I, Vázquez DP, Winfree R, Adams L, Crone EE, Greenleaf SS, Keitt TH, Klein A-M, Regetz J, Ricketts TH (2007) Pollination and other ecosystem services produced by mobile organisms: a conceptual framework for the effects of land-use change. Ecol Lett 10:299314

Kuhlmann M, Guo D, Veldtman R, Donaldson J (2012) Consequences of warming up a hotspot: species range shifts within a centre of bee diversity. Divers Distrib $18: 885-897$

Lima-Ribeiro MS, Varela S, González-Hernández J, Oliveira G, Diniz-Filho JAF, Terribile LC (2015) ecoClimate: a database of climate data from multiple models for past, present, and future for Macroecologists and Biogeographers. Biodiversity Informatics 10:1-21

Lima-Ribeiro MS, Varela S, González-Hernández J, Oliveira G, Diniz-Filho JAF, Terribile LC. The ecoClimate Database. http://ecoclimate.org. Accessed 21 February 2015 
Leadley P, Pereira HM, Alkemade R, Fernandez-Manjarres JF, Proenca V, Scharlemann JPW, Walpole MJ (2010) Biodiversity Scenarios: Projections of 21st Century Change in Biodiversity and Associated Ecosystem Services. In: Secretariat of the Convention on Biological Diversity (ed. Diversity SotCoB). Published by the Secretariat of the Convention on Biological Diversity, Montreal, $132 \mathrm{p}$. Technical Series no. 50.

Martins AC, Silva DP, De Marco P, Melo, GAR (2015) Species conservation under future climate change: The case of Bombus bellicosus, a potentially threatened South American bumblebee species. J Insect Conserv 19:33-43

Melo-Silva C, Gomes FL, Gonçalves BB, Bergamini LL, Bergamini BAR, Elias MAS, Franceschinelli EV (2013) Native bees pollination tomato flowers and increase fruit production. J Pollinat Ecol 11:41-45

Memmott J, Craze PG, Waser NM, Price MV (2007) Global warming and the disruption of plant-pollinator interactions. Ecol Lett 10:710-717

Ollerton J, Winfree R, Tarrant S (2011) How many flowering plants are pollinated by animals? Oikos 120:321-326

Polce C, Garratt MP, Termansen M, Ramirez-Villegas J, Challinor AJ, Lappage MG, Boatman ND, Crowe A, Endalew AM, Potts SG, Somerwill KE, Biesmeijer JC (2014) Climate-driven spatial mismatches between British Orchards and their pollinators: increased risks of pollination deficits. Glob Change Biol 20:28152828

Potts SG, Biesmeijer JC, Kremen C, Neumann P, Schweiger O, Kunin WE (2010) Global pollinator declines: trends, impacts and drivers. Trends Ecol Evol $25: 345-353$ 
Pounds JA, Bustamante MR, Coloma LA, Consuegra JA, Fogden MP, Foster PN, La Marca E, Masters KL, Merino-Viteri A, Puschendorf R, Ron SR, SánchezAzofeifa GA, Still CJ, Young, BE (2006) Widespread Amphibian Extinctions from Epidemic Disease Driven by Global Warming. Nature 439:161-167

R Core Team (2015) R: a language and environment for statistical computing. R Foundation for Statistical Computing, Vienna, Austria

Rader R, Reilly J, Bartomeus I, Winfree R (2013). Native bees buffer the negative impact of climate warming on honey bee pollination of watermelon crops. Glob Change Biol 19:3103-3110

Ricketts TH, Regetz J, Steffan-Dewenter I, Cunningham SA, Kremen C, Bogdanski A, Gemmill-Herren B, Greenleaf SS, Klein A-M, Mayfield MM, Morandin LA, Ochieng A, Potts SG, Viana BF (2008) Landscape effects on crop pollination services: are there general patterns? Ecol Lett 11:499-515

Root TL, Price JT, Hall KR, Schneider SH, Rosenzweig C, Pounds JA (2003) Fingerprints of global warming on wild animals and plants. Nature 421:57-60

Rosa AS, Blochtein B, Lima DK (2011) Potential honey bee contribution to canola pollination in southern Brazil. Sci Agric 68:255-259

Roubik DW (1995) Pollination of cultivated plants in the tropics. In: FAO Agricultural Services Bulletin 118, FAO, Rome, 196 pp.

Rounsevell MDA, Ewert F, Reginster I, Leemans R, Carter TR (2005) Future scenarios of european agricultural land use II. Projecting changes in cropland and grassland. Agr Ecosyst Environ 107:117-135 
Santos AB, Nascimento FS (2011) Diversidade de visitantes florais e potenciais polinizadores de Solanum lycopersicum (Linnaeus) (Solanales: Solanaceae) em cultivos orgânicos e convencionais. Neotropical Biology and Conservation 6:162-169

Santos AOR, Bartelli BF, Nogueira-Ferreira FH (2014) Potential pollinators of tomato, Lycopersicon esculentum (Solanaceae), in open crops and the effect of a solitary bee in Fruit Set and Quality. J Econ Entomol 107:987-994

Steffan-Dewenter I, Potts SG, Packer L. (2005) Pollinator diversity and crop pollination services are at risk. Trends Ecol Evol 20: 651-653

Silva DP, Macêdo ACBA, Ascher JS, De Marco P (2015) Range increase of a neotropical orchid bee under future Scenarios of climate change. J Insect Conserv 19:901-910

Taylor KE, Stouffer RJ, Meehl GA (2009) A summary of the CMIP5 experimental design. http://cmippcmdi.llnl.gov/cmip5/docs/Taylor_CMIP5_design.pdf. Accessed 24 March 2014

Taylor KE, Stouffer RJ, Meehl GA (2012) An Overview of CMIP5 and the Experiment Design. Bull Amer Meteor Soc 93:485-498

Terribile LC, Lima-Ribeiro MS, Araújo MB, Bizão N, Collevatti RG, Dobrovolski R, Franco AA, Guilhaumon F, Lima JDS, Murakami DM, Nabout JC, de Oliveira G, de Oliveira LK, Rabelo SG, Rangel TF, Simon LM, Soares TN, Telles MPDC, Diniz-Filho JAF (2012) Areas of Climate Stability of Species Ranges in the Brazilian Cerrado: Disentangling Uncertainties through Time. Nat Conserv $10: 152-159$

Thuiller W, Lafourcade B, Engler R, Araújo MB (2009) BIOMOD - A platform for ensemble forecasting of species distributions. Ecography 32:369-373 
Vaughan M, Hoffman Black SH (2006) Improving forage for native bee crop pollinators. USDA Agroforestry Notes 33:1-4

Veddeler D, Olschewski R, Tscharntke T, Klein AM. (2008) The contribution of nonmanaged social bees to coffee production: new insights based on farm-scale yield data. Agroforest Syst 73:109-114

Warren R, VanDerWal J, Price J, Welbergen JA, Atkinson I, Ramirez-Villegas J, Osborn TJ, Jarvis A, Shoo LP, Williams SE, Lowe J (2013) Quantifying the benefit of early climate change mitigation in avoiding biodiversity loss. Nature Clim Chang 3:678-682 


\section{Figures and tables Captions:}

Figure 1. Shifts in suitable habitat areas of five wild bee species (expressed as proportional reductions compared with the present scenarios) in an optimistic (green bars), and a pessimistic scenario (grey bars) of future climate change for the year 2100 . Vertical spreads represent the shifts computed using the $2.5 \%$ and the $97.5 \%$ quantiles of all suitability values obtained for each cell. A. callichroa (Augochloropsis callichroa), B. morio (Bombus morio), C. tarsata (Centris tarsata), Ex. analis (Exomalopsis analis) and Eu.nigrita (Eulaema nigrita).

Figure 2. Consensus maps for five species of native bees of the current, optimistic (RCP 2.6 - 2100) and pessimistic (RCP 2.6 - 2100) scenarios of future climate change for the year 2100. Five models were combined through an ensemble of forecasts to generate these consensus maps.

Table 1. Agreement between tomatoes cropped areas in hectares and the presence of five bee species in these areas in the current, optimistic (RCP 2.6) and pessimistic (RCP 8.5) future scenarios. The values in parentheses represent the percentage the concordance between the area planted tomato in Brazil and occurs in suitable cells for each species. Ex. analis (Exomalopsis analis), B. morio (Bombus morio), Eu. nigrita (Eulaema nigrita), C. tarsata (Centris tarsata) and A. callichroa (Augochloropsis callichroa). 


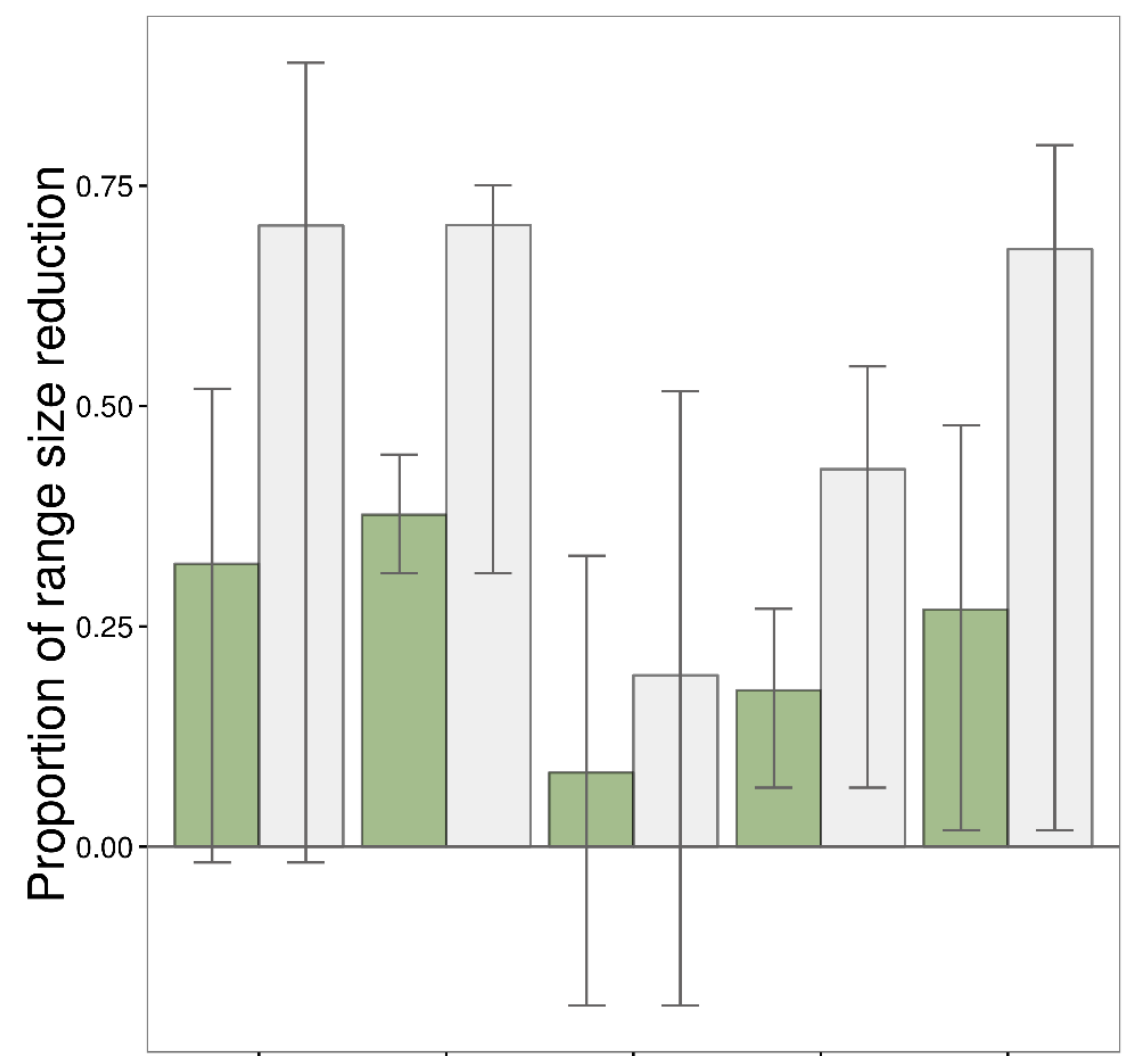

A. callichroa B. morio C. tarsata Ex.analis Eu. nigrita

Figure 1. 


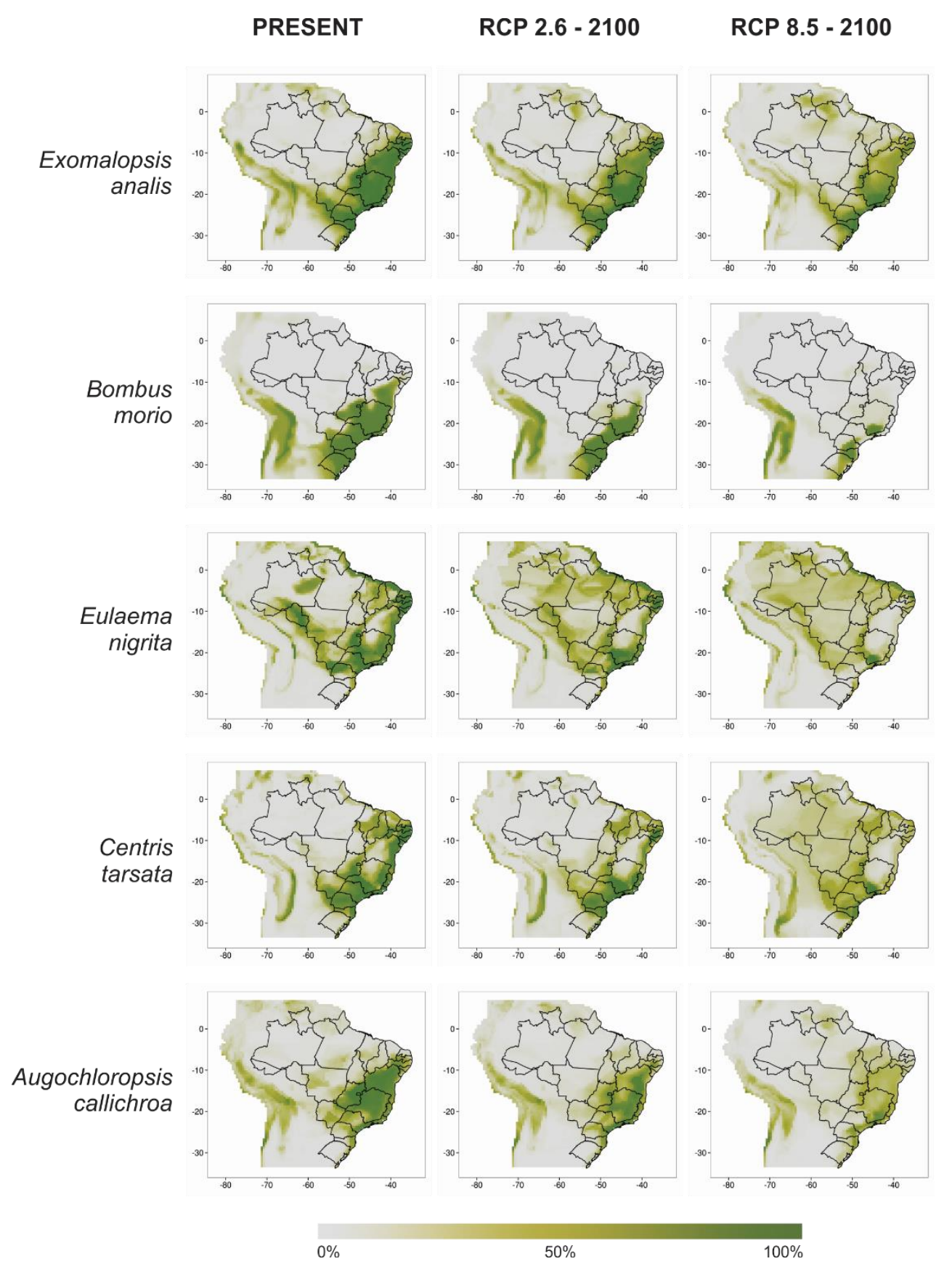

Figure 2. 
Table 1.

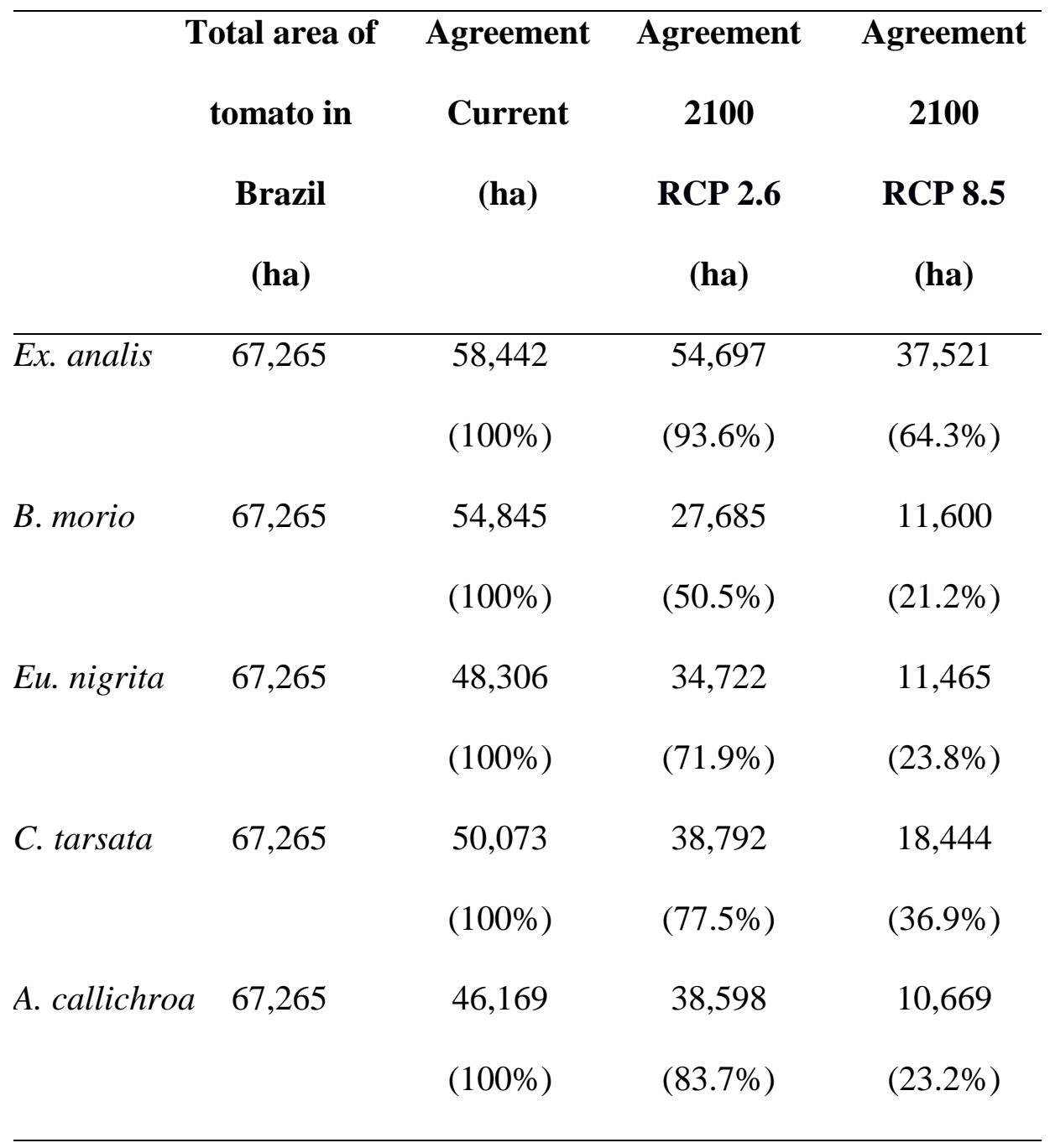




\section{Online Resource 1}

\section{Number of points for each specie:}

Exomalopsis analis: 144

Bombus morio: 113

Eulaema nigrita: 284

Centris tarsata: 188

Augochloropsis callichroa: 35

\section{Data providers}

- GBIF (www.gbif.org)

- Centro de Referência em Informação Ambiental: Coleção de Entomologia do Laboratório de Biologia Vegetal.

- Universidade Federal da Paraíba, UFPB: Coleção Entomológica do Departamento de Sistemática e Ecologia - DSEC

- Centro de Referência em Informação Ambiental: Coleção Entomológica Paulo Nogueira-Neto - IB/USP

- Centro de Referência em Informação Ambiental: Laboratório de Ecologia e Biogeografia de Insetos da Caatinga.

- Centro de Referência em Informação Ambiental: Coleção Entomológica Pe. Jesus Santiago Moure (Hymenoptera).

- Coleção de Abelhas do Museu de Ciências e Tecnologia da PUCRS. 
- Instituto Nacional de Pesquisas da Amazônia - INPA: Hymenoptera Collection - Instituto Nacional de Pesquisas da Amazônia (INPA).

- Centro de Referência em Informação Ambiental: Coleção Entomológica Moure e Costa.

- SpeciesLink (specieslink.cria.org.br)

- Universidade de São Paulo, USP: Coleção Entomológica Paulo Nogueira-Neto - IB/USP-CEPANN

- Universidade Federal da Paraíba, UFPB: Coleção Entomológica do Departamento de Sistemática e Ecologia - DSEC

- Universidade Federal de Campina Grande, UFCG: Laboratório de Ecologia e Biogeografia de Insetos da Caatinga- LEBIC

- Universidade Federal de Minas Gerais: Coleção de DNA, tecidos, células e subamostras biológicas do Centro de Coleções Taxonômicas da UFMG - UFMG-BDT.

- Universidade Estatual de Ponta Grossa, UEPG: Coleção Entomológica dos Campos Gerais do Paraná - UEPG, CECG.

- Empresa Baiana de Desenvolvimento Agrícola, EBDA: Coleção Entomológica Moure \& Costa-EBDA.

- Universidade de Santa Cruz do Sul: Coleção Entomológica de Santa Cruz do Sul- CESC.

- Instituto Nacional de Pesquisas da Amazônia, INPA: Coleção de Hymenoptera INPA- INPA- Hymenoptera 
- Pontifícia Universidade Católica do Rio Grande do Sul, PUCRS: Coleção de Abelhas do Museu de Ciências e Tecnologia da PUCRS.

- Universidade Federal do Espírito Santo, UFES: Coleção Entomológica da Universidade Federal do Espírito Santo.

- Universidade Estadual de Campinas, UNICAMP: Museu de Zoologia/Universidade Estadual de Campinas, ZUEC Hymenoptera.

- Universidade Federal de Juiz de Fora: Herbário Leopoldo KriegerHerbário CESJ.

- Universidade Federal do Paraná, UFPR: Coleção Entomológica Pe. Jesus Santiago Moure (Hymenoptera)- DZUP - Hymenoptera.

- Universidade Federal do Vale do São Francisco: Herbário Vale do São Francisco- HVASF.

- Universidade Estadual de Londrina, UEL: Museu de Zoologia da Universidade Estadual de Londrina - Coleção de Abelhas - MZUELabelhas.

- Fundação de Amparo à Pesquisa do Estado de São Paulo, FAPESP: Sistema de Informação do Programa Biota/Fapesp.

- Universidade Federal de Minas Gerais, UFMG: coleção do laboratório de Sistemática e Ecologia de Abelhas, professor Dr. Fernando A. Silveira.

- Universidade Federal Goiás, UFG: Coleção do laboratório de biologia reprodutiva, professora Dra. Edivani V. Franceschinelli.

- Scholar Google (scholar.google.com.br) 
- Web

of

Science

(http://apps-

webofknowledge.ez54.periodicos.capes.gov.br/WOS_GeneralSearch_input .do?product=WOS\&search_mode=GeneralSearch\&SID=2BsjZOyrx2UKG 7FXGcG\&preferencesSaved=).

\section{Points obtained through the references below}

Aguiar AJC, Martins CF (2002) Abelhas e vespas solitárias em ninhos-armadilha na Reserva Biológica Guaribas (Mamanguape, Paraíba, Brasil). Rev Bras Zool $19: 101-116$

Aguiar CML, Zanella FCV (2005) Estrutura da comunidade de abelhas (Hymenoptera: Apoidea: Apiformis ) de uma área na margem do domínio da caatinga (Itatim, BA). Neotrop Entomol 34:15-24

Aguiar CML, Garófalo CA, Almeida GF (2004) Nesting biology of Centris (Hemisiella) tarsata Smith ( Hymenoptera, Apidae, Centridini ). Rev Bras Zool $21: 477-486$

Aguiar CML, Zanella FCV, Martins CF, Carvalho CAL de. (2003) Plantas visitadas por Centris spp. (Hymenoptera: Apidae) na Caatinga para obtenção de recursos florais. Neotrop Entomol 32:247-259

Aguiar WM, Gaglinone MC (2008) Comunidade de abelhas Euglossina (Hymenoptera: Apidae) em remanescentes de mata estacional semidecidual sobre tabuleiro no estado do Rio de Janeiro. Neotrop Entomol 37:118-125

Alemán M, Figueroa-Fleming T, Etcheverry Á, Sühring S, Ortega-Baes P (2014) The explosive pollination mechanism in Papilionoideae (Leguminosae): an analysis with three Desmodium species. Plant syst evol 300:177-186 
Alves dos Santos I (2002) Flower-visiting bees and the breakdown of the tristylous breeding system of Eichhornia azurea (Swartz) Kunth (Pontederiaceae). Biol J Linnean Soc 77:499-507

Alves JE, Freitas BM (2007) Requerimentos de polinização da goiabeira. Cienc Rural $37: 1281-1286$

Amorim ME, De Marco P (2011) Pollination of Byrsonima coccolobifolia: shortdistance isolation and possible causes for low fruit production. Braz $\mathbf{J}$ Biol 71:709-717

Antonini Y, Souza HG; Jacobi CM, Mury FB (2005) Diversidade e comportamento dos insetos visitantes florais de Stachytarpheta glabra Cham. (Verbenaceae), em uma área de campo ferruginoso, Ouro Preto, MG. Neotrop Entomol 34:555-564

Azevedo RL, Carvalho CAL de, Pereira LL, Nascimento AS do (2007) Abelhas ( Hymenoptera: Apoidea ) visitantes das flores do feijão guandu no Recôncavo Baiano, Brasil. Cienc. Rural 37:1453-1457

Barbola IF, Larroca S, Almeida MC, Nascimento EA (2006) Floral biology of Stachytarpheta maximiliani Scham. (Verbenaceae) and its floral visitors. Rev Bras Entomol 50:498-504

Barros MG (2001) Pollination ecology of Tabebuia aurea (Manso) Benth. \& Hook. and T. ochracea (Cham.) Standl. (Bignoniaceae) in Central Brazil cerrado vegetation. Rev Bras Bot24:255-261

Batalha-Filho H, Nunes LA, Pereira DG, Waldschmidt AM (2004) Inventário da fauna de abelhas (Hymenoptera, Apoidea) em uma área de caatinga da região de Jequié, BA. Biosci J 23:24-29

Bezerra CP, Martins CF (2001) Diversidade de Euglossinae (Hymenoptera, Apidae) em dois fragmentos de Mata Atlântica localizados na região urbana de João Pessoa, 
Paraíba, Brasil. Rev Bras Zool 18:823-835

Bezerra ES, Lopes AV, Machado I. C (2009) Biologia reprodutiva de Byrsonima gardnerana A. Juss. (Malpighiaceae) e interações com abelhas Centris (Centridini) no Nordeste do Brasil. Rev Bras Bot 32: 95-108

Bezerrra ELS, Machado IC (2003) Biologia floral e sistema de polinização de Solanum stramonifolium Jacq. (Solanaceae) em remanescente de Mata Atlântica, Pernambuco. Acta Bot Bras17:247-257

Boff S, Araujo AC, Pott A (2013) Bees (Hymenoptera: Apoidea) and flowers in natural forest patches of southern Pantanal. Biota Neotrop 13:46-56

Boti JB, Oliveira BR, Oliveira ML (2014) Insetos visitantes florais e potenciais polinizadores da aceroleira (Malpighia Emarginata Dc, Malphighiaceae) em plantas encontradas em quintais na zona urbana de Colatina-ES, III Simposio sobre Biodiversidade da Mata Atlantica 171-174

Boti JB, Campos LAO, De Marco Jr P, Vieira MF (2005) Influência da distância de fragmentos florestais na polinização da goiabeira. Rev Ceres 52:863-874

Brito CMS, Rêgo MMC (2001) Community of male euglossini bees (Hymenoptera: Apidae) in a secondary forest, Alcântara, MA, Brazil. Braz J Biol 61:631-638

Canela MBF, Sazima M (2005) The Pollination of Bromelia antiacantha (Bromeliaceae) in Southeastern Brazil: Ornithophilous versus Melittophilous Features. Plant Biol 7:411-416

Carvalho AMC, Oliveira PE (2010) Estrutura da guilda de abelhas visitantes de Matayba guianensis AUBL. (sapindaceae) em vegetação do cerrado. Oecologia Australis 14:40-66 
Carvalho AT, Santos-Andrade FG, Schlindwein C (2007) Baixo sucesso reprodutivo em Anemopaegma laeve (Bignoniaceae) no Parque Nacional do Catimbau, Pernambuco. Rev Bras Biociênc 5:102-104

Carvalho CAL, Marques OM, Vidal CA, Neves AMS (2001) Comportamento forrageiro de abelhas (Hymenoptera, Apoidea) em flores de Solanum Palinacanthum Dunal (Solanaceae). Rev Bras Zoociênc 3:35-44

Costa AJC, Guimarães-Dias F, Perez-Maluf R (2008) Abelhas (Hymenoptera: Apoidea) visitantes das flores de urucum em Vitória da Conquista, BA. Cienc. Rural $38: 534-537$

Costa CBN, Costa JAS, Ramalho M (2006) Biologia reprodutiva de espécies simpátricas de Malpighiaceae em dunas costeiras da Bahia, Brasil. Rev Bras Bot 29:103-114

Cortopassi-Laurino M, Knoll FRN, Imperatriz-Fonseca VLI (2003) Nicho trófico e abundância de Bombus morio e Bombus atratus em diferentes biomas brasileiros. Apoidea Neotropica 285-295

De Luca PA, Vallejo-Marín M (2013) What's the "buzz" about? The ecology and evolutionary significance of buzz-pollination. Curr Opin in Plant Biol 16:429435

Del-Claro K, Torezan-Silingardi HM, Belchior C, Alves-Silva E (2009) Ecologia comportamental: uma ferramenta para a compreensão das relações animaisplantas. Oecologia Australis 13:16-26

Deprá MS (2012) Abelhas polinizadoras de Solanum lycopersicum L. (solanaceae) em áreas de plantio inseridas em diferentes paisagens no município de São José de Ubá, RJ. Dissertação, Universidade Universidade Estadual do Norte Fluminense Darcy Ribeiro 
Deprá MS, Delaqua GCG, Gaglianone MC (2011) Influência da cobertura florestal sobre a riqueza e frequência de abelhas polinizadoras do tomateiro (Solanum lycopersicum L.) em áreas de plantio no município de São José de Ubá, RJ. Resumos do VII Congresso Brasileiro de Agroecologia, 6:1-6

Dórea MC, Santos FAR, Lima LCLE, Figueroa LER (2009) Análise polínica do resíduo pós-emergência de ninhos de Centris tarsata Smith (Hymenoptera: Apidae, Centridini). Neotrop Entomol 38:197-202

Dutra JCS, Machado VLL (2001) Entomofauna visitante de Stenolobium stans (Juss.) Seem (Bignoniaceae), durante seu período de floração. Neotrop Entomol 30:4353

Etcheverry AV, Aleman MM, Fleming TF (2008) Flower morphology, pollination biology and mating system of the complex flower of Vigna caracalla (Fabaceae: Papilionoideae). Ann Botany 102:305-316

Faria Junior LRR, Bendini JN, Barreto LMRC (2008) Eficiência polinizadora de Apis mellifera L. e polinização entomófila em pimentão variedade cascadura ikeda. Bragantia 67:261-266

Farias RCAP, Madeira-da-Silva MC, Pereira-Peixoto MH, Martins CF (2008) Composição e sazonalidade de espécies de euglossina (Hymenoptera: Apidae) em mata e duna na área de proteção ambiental da barra do rio mamanguape, Rio Tinto, PB. Neotrop Entomol 37:253-258

Fidalgo ADO, Kleinert ADMP (2009) Reproductive biology of six Brazilian Myrtaceae:is there a syndrome associated with buzz-pollination? New Zeal J Bot $47: 355-365$ 
Figueiredo PS, Ribeiro EKMD, Lacerda DMA, Girnos EC (2009) Estratégia reprodutiva de Cochlospermum orinocense (Kunth) Steud.: fenologia, biologia floral e sistema de cruzamento em uma espécie pioneira de florestas. Rev Bras Bot 32:781-792

Fracasso CM, Sazima M (2004) Polinização de Cambessedesia hilariana (Kunth) DC. (Melastomataceae): sucesso reprodutivo versus diversidade, comportamento e frequiência de visitas de abelhas. Rev Bras Bot 27:797-804

Freitas BM, Alves JE, Araujo ZB (1999) Pollination requirements of West Indian cherry ( Malpighia emarginata) and its putative pollinators, Centris bees, in NE Brazil. J Agr Sci 133:303-311

Freitas BM, Paxton RJ (1998) A comparison of two pollinators: The introduced honey bee Apis mellifera and an indigenous bee Centris tarsata on cashew Anacardium occidentale in its native range of NE Brazil. J Appl Ecol 35:109-121

Gaglianone MC, Rocha HHS, Benevides CR, Junqueira CN, Augusto SC (2010) Importância de Centridini (apidae) na polinização de plantas de interesse agrícola: o maracujá-doce (Passiflora alata CURTIS) como estudo de caso na região sudeste do Brasil. Oecologia Australis, 14(01), 152-164.

Galetto L, Torres C. (2010) Nectar sugar composition and pollinators for the naturalized exotic Leonurus japonicus (Lamiaceae) in central Argentina. The International Journal of Plant Reproductive Biology 2:1-4

Garófalo CA (2008) Abelhas (Hymenoptera, Apoidea) nidificando em ninhos-armadilha na estação ecológica dos caetetus, Gália, SP. Anais do VIII Encontro sobre Abelhas 208-217

Gimenes M, Lobão C (2006) A polinização de Krameria bahiana B.B. Simpson (Krameriaceae) por abelhas (Apidae) na restinga, BA. Neotrop Entomol 35:440- 
Gimenes M, Figueiredo NA, Santos AHP (2006) Atividades relacionadas à construção e aprovisionamento de ninhos de Xylocopa subcyanea (Hymenoptera, Apidae) em uma área de restinga na Bahia, Brasil. Iheringia Sér Zool 96:299-304

Gonçalves RB, Melo GAR (2005) A comunidade de abelhas (Hymenoptera, Apidae s. 1.) em uma área restrita de campo natural no Parque Estadual de Vila Velha, Paraná: diversidade, fenologia e fontes florais de alimento. Rev Bras Entomol 49:557-571

Guedes RS, Zanella FCV, Martins CF, Schlindwein C (2011) Déficit de polinização da aceroleira no período seco no semiárido paraibano. Rev Bras Frutic 33:465-471

Guerra TJ, Romero GQ, Benson WW (2010) Flower mites decrease nectar availability in the rain-forest bromeliad Neoregelia johannis. J Trop Ecol 26:373-379

Guimarães RA, Pérez-Maluf R, Castellani MA (2005) Abelhas (Hymenoptera: Apoidea) visitantes das flores da Goiaba em pomar comercial de Salinas, MG. Bragantia 68:23-27

Imperatriz-Fonseca VL, Alves-dos-Santos I, Santos Filho PdeS, Engels W, Ramalho M, Wilms W, Aguilar JBV, Pinheiro-Machado CA, Alves DA, Kleinert AMP (2011) Checklist das abelhas e plantas melitófilas no Estado de São Paulo, Brasil. Biota Neotrop 11:631-655

Jacobi CM, Antonini Y (2008) Pollinators and defence of Stachytarpheta glabra (Verbenaceae) nectar resources by the hummingbird Colibri serrirostris (Trochilidae) on ironstone outcrops in south-east Brazil. J Trop Ecol 24:301-308

Janzen DH, DeVries PJ, Higgins ML, Kimsey LS (1982) Seasonal and site variation in Costa Rican Euglossine bees at chemical baits in lowland deciduous and evergreen forests. Ecology 63:66-74 
Jamhour J, Laroca S (2004) Uma comunidade de abelhas silvestres (Hym., Apoidea) de Pato Branco (PR-Brasil): diversidade, fenologia, recursos florais e aspectos biogeográficos. Acta Biol Parana 33:27-119

Justino DG, Augusto SC (2012) Avaliação da eficiência de coleta utilizando armadilhas aromáticas e riqueza de Euglossini (Hymenoptera, Apidae) em áreas de cerrado do triângulo mineiro. Rev Bras Zoociênc12:227-239

Kamke R, Schmid S, Zillikens A, Lopes BC, Steiner J (2011) The importance of bees as pollinators in the short corolla bromeliad Aechmea caudata in southern Brazil. Flora 206:749-756

Kiill LHP, Drumond MA (2001) Biologia floral e sistema reprodutivo de Gliricidia sepium (JACQ.) STEUD. (Fabaceae- Papilionoidae) na região de Petrolina, Pernambuco. Cienc. Rural 31:597-601

Kiill LHP, Haji FNP, Lima PCF (2000) Visitantes florais de plantas invasoras de áreas com fruteiras irrigadas. Sci Agric 57:575-580

Koschnitzke C, Sazima M (1997) Biologia floral de cinco espécies de Passiflora L. (Passifloraceae) em mata semidecídua. Rev Bras Bot 20:119-126

Krug C, Alves-dos-Santos I (2008) O uso de diferentes métodos para amostragem da fauna de abelhas (Hymenoptera:Apoidea), um estudo em floresta ombrófila mista em Santa Catarina. Neotrop Entomol 37:265-278

Leite AV, Machado IC (2009) Biologia reprodutiva da "catingueira" (Caesalpinia pyramidalis Tul., Leguminosae-Caesalpinioideae), uma espécie endêmica da Caatinga. Rev Bras Bot 32:79-88

Lenzi M, Orth AF, Laroca S (2003) Associação das abelhas silvestres (Hym., Apoidea) visitantes das flores de Schinus terebinthifolius (Anacardiaceae), na Ilha de Santa Catarina (sul do Brasil). Acta Biol Parana 32:107-127 
Macedo JF, Martins RP (1998) Potencial da erva daninha Waltheria americana (sterculiaceae) no manejo integrado de pragas e polinizadores: Visitas de Abelhas e Vespas. Anais da Sociedade Entomológica do Brasil 27:29-40

Madeira-da-Silva MC, Martins CF (2003) Abelhas (Hymenoptera, Apoidea, Apiformes) de uma área de restinga, Paraíba, Nordeste do Brasil: Abundância, diversidade e sazonalidade. Rev Ne Bio 17:75-90

Manente-Balestieri FCDL, Machado VLL (1999) Entomofauna visitante das flores de Cassia spectabilis (L.) DC. (Leguminosae). Anais da Sociedade Entomológica do Brasil 28:429-437

Martins CF, Souza AKP (2005) Estratificação vertical de abelhas Euglossina (Hymenoptera, Apidae) em uma área de Mata Atlântica, Paraíba, Brasil. Rev Bras Zool 22:913-918

Martins GF, Serrão JE (2004) A comparative study of the ovaries in some brazilian bees. Pap Avulsos de Zool 43:45-53

Mattozo VC, Faria LRR, Melo GAR (2011) Orchid bees (Hymenoptera: Apidae) in the coastal forests of Southern Brazil: diversity, efficiency of sampling methods and comparison with other atlantic forest surveys. Pap Avulsos de Zool 51:505-515

Melo-Silva C, Peres MP, Neto JNM, Leal IAB (2014) Biologia reprodutiva de $L$. leucocephala (Lam.) R. de Wit (Fabaceae: Mimosoideae): sucesso de uma espécie invasora. Neotropical Biology and Conservation 9:91-97

Mendes FN, Rêgo MMC (2006) Nidificação de Centris ( Hemisiella ) tarsata Smith ( Hymenoptera, Apidae, Centridini ) em ninhos-armadilha no Nordeste do Maranhão, Brasil. Rev Bras Entomol 51:382-388 
Mendes FN, Rêgo MMC, Carvalho CC (2008) Abelhas Euglossina (Hymenoptera, Apidae) coletadas em uma monocultura de eucalipto circundada por Cerrado em Urbano Santos, Maranhão, Brasil. Iheringia Sér Zool 98:285-290

Mesquita TMS, Vilhena AMGF, Augusto SC (2009) Ocupação de ninhos-armadilha por Centris (Hemisiella) tarsata Smith, 1874 e Centris (Hemisiella) vittata Lepeletier, 1841 (Hymenoptera: Apidae: Centridini) em áreas de cerrado. Biosci J 25:124-132

Mesquita TMS, Augusto SC (2011) Diversity of trap-nesting bees and their natural enemies in the Brazilian savanna. Trop Zool 24:127-144

Milet-Pinheiro P, Schlindwein C (2005) Do euglossine males (Apidae, Euglossini) leave tropical rainforest to collect fragrances in sugarcane monocultures? Rev Bras Zool 22:853-858

Morato EF, Garcia MVB, Campos LAO (1999) Biologia de Centris Fabricius (Hymenoptera, Anthophoridae, Centridini) em matas contínuas e fragmentos na Amazônia Central. Rev Bras Zool 16:1213-1222

Muniz JM, Pereira ALC, Valim JOS, Campos WG (2013) Patterns and mechanisms of temporal resource partitioning among bee species visiting basil (Ocimum Basilicum) Flowers. Arth-Plant Int 7:491-502

Nascimento ALO, Garófalo CA (2010) Abelhas (Hymenoptera, Apoidea) nidificando em ninhos-armadilha no Parque Estadual da Serra do Mar, Ubatuba, SP. Anais do IV Encontro sobre Abelhas 139-146

Nascimento ET, Pérez-Maluf R, Guimarães RA, Castellani MA (2011) Diversidade de abelhas visitantes das flores de Citrus em pomares de laranjeira e tangerineira. Rev Bras Frutic 33:111-117 
Nassar NMA (1990) Insetos polinizadores e seus comportamentos nas espécies silvestres da mandioca, Manihot spp. Journal of Brasilian Asssociation for Advancement of Science 42:703-705

Neves EL, Taki H, Silva FO, Viana BF, Kevan PG (2006) Flower characteristics and visitors of Merremia macrocalyx (Convolvulaceae ) in the chapada diamantina, Bahia , Brazil. Lundiana 7:97-102

Neves EL,Viana BF (1997) Inventário da Fauna de Euglossinae (Hymenoptera, Apidae) do baixo sul da Bahia, Brasil. Rev Bras Zool 14:831-837

Nemesio A (2002) Notes on the occurrence of an aberrant coloration in Eulaema nigrita (Hymenoptera: Apidae: Euglossina) in forest fragments in Southeastern Brazil. Lundiana 3:75-77

Nemesio A, Faria-Junior LRR (2004) First assessment of the orchid-bee fauna (Hymenoptera: Apidae) at Parque Estadual do Rio Preto, a cerrado area in Southeastern Brazil. Lundiana 5:113-117

Oliveira JEM, Nicodemo D, Oliveira FF (2015) Contribuição da polinização entomófila para a produção de frutos de aceroleira. Pesqui Agropecu Trop 45:56-65

Oliveira FS, Mendonça MWA, Vidigal MCS, Rêgo MMC, Albuquerque PMC (2010) Comunidade de abelhas (Hymenoptera, Apoidea) em ecossistema de dunas na praia de panaquatira, São José de Ribamar, Maranhão, Brasil. Rev Bras Entomol 54:82-90

Oliveira MIB, Sigrist MR (2008) Fenologia reprodutiva, polinização e reprodução de Dipteryx alata Vogel (leguminosae-papilionoideae) em Mato Grosso Do Sul, Brasil. Rev Bras Bot 31:195-207 
Ortega-Baes P, Saraiva M, Sühring S, Godínez-Alvarez H, Zamar M (2011) Reproductive biology of Echinopsis terscheckii (Cactaceae): the role of nocturnal and diurnal pollinators. Plant Biol 13:33-40

Pereira AC, Silva JB, Goldenberg R, Melo GAR, Varassin IG (2011) Flower color change accelerated by bee pollination in Tibouchina (Melastomataceae). Flora 206:491-497

Peruquetti RC, Campos LAO, Coelho CDP, Abrantes CVM, Lisboa LCO (1999) Abelhas Euglossini (Apidae) de áreas de Mata Atlântica: abundância, riqueza e aspectos biológicos. Rev Bras Zool 16:101-118

Pinheiro M, Sazima M (2007) Visitantes florais e polinizadores de seis espécies arbóreas de leguminosae melitófilas na mata atlântica no sudeste do brasil. Rev Bras Biociênc 5:447-449

Pires EP, Pompeu DC, Souza-Silva M (2012) Nidificação de vespas e abelhas solitárias (Hymenoptera:Aculeata) na reserva biológica boqueirão, Ingaí, Minas Gerais. Biosci J 28:302-311

Proença CEB, Gibbs PE (1994) Reproductive biology of eight sympatric Myrtaceae from Central Brazil. New Phytol 126:343-354

Ramalho AV, Gaglianone MC, Oliveira ML (2009) Comunidades de abelhas Euglossina (Hymenoptera, Apidae) em fragmentos de Mata Atlântica no Sudeste do Brasil. Rev Bras Entomol 53:95-101

Ramalho M (2004) Stingless bees and mass flowering trees in the canopy of Atlantic Forest: a tight relationship. Acta Bot Bras18:37-47 
Ramalho M, Rosa JF (2010) Ecologia da interação entre as pequenas flores de quilha de Stylosanthes viscosa Sw. (Faboideae) e as grandes abelhas Xylocopa (Neoxylocopa) cearensis Ducke, 1910 (Apoidea, Hymenoptera), em duna tropical. Biota Neotrop 10:93-100

Raw A (2000) Foraging behaviour of wild bees at hot pepper flowers (Capsicum апnиит) and its possible influence on cross pollination. Ann Botany 85:487-492

Rebelo JMM, Cabral AJM (1997) Abelhas Euglossine de Barreirinhas, zona do litoral da baixada oriental maranhense. Acta Amaz 27:145-152

Rebelo JMM, Garófalo CA (1997) Comunidades de machos de Euglossini (Hymenoptera: Apidae) em Matas Semidecíduas do Nordeste do Estado de São Paulo. Anais da Sociedade Entomológica do Brasil 26:243-255

SanMartin-Gajardo I, Sazima M (2004) Non-euglossine bees also function as pollinators of Sinningia Species (Gesneriaceae) in Southeastern Brazil. Plant Biol 6:506-512

Santos AB, Nascimento FS (2011) Diversidade de visitantes florais e potenciais polinizadores de Solanum lycopersicum (Linnaeus) (Solanales: Solanaceae) em cultivos orgânicos e convencionais. Neotropical Biology and Conservation 6:162-169

Santos AM, Sofia SH (2002) Horário de atividade de machos de Euglossinae (Hymenoptera, Apidae) em um fragmento de floresta semidecídua no norte do Estado do Paraná. Acta Sci 24:375-381

Santos AOR, Bartelli BF, Nogueira-Ferreira FH (2014) Potential pollinators of tomato, Lycopersicon esculentum (Solanaceae), in open crops and the effect of a solitary bee in Fruit Set and Quality. J Econ Entomol 107:987-994 
Santos GMM, Carvalho CAL, Aguiar CML, Macêdo LSSR, Mello MAR (2013) Overlap in trophic and temporal niches in the flower-visiting bee guild (hymenoptera, apoidea) of a tropical dry forest. Apidologie 44:64-74

Santos MJ, Machado IC, Lopes AV (2005) Biologia reprodutiva de duas espécies de Jatropha L. (Euphorbiaceae) em Caatinga, Nordeste Do Brasil. Rev Bras Bot 28:361-373

Santos SKD, Gomes LP, Souza LEC, Waldschmidt AM (2007) Visitantes florais do caju anão precoce (Anacardium occidentale L.) em uma área de caatinga no município de Jequié - BA. Anais do VIII Congresso de Ecologia do Brasil 1-2

Santos, R. M. et al., (2013) The larval provisions of the crop pollinator Centris analis: pollen spectrum and trophic niche breadth in an agroecosystem. Apidologie 44:630-641

Silva DP, De Marco P (2014) No evidence of habitat loss affecting the orchid bees Eulaema nigrita Lepeletier and Eufriesea auriceps Friese (Apidae: Euglossini) in the Brazilian Cerrado Savanna. Neotrop Entomol 43:509-518

Silva FO, Viana BF, Neves EL (2001) Biologia e arquitetura de ninhos de Centris ( Hemisiella ) tarsata Smith ( Hymenoptera: Apidae: Centridini). Neotrop Entomol 30:541-545

Silva ALG, Pinheiro MCB (2007) Biologia floral e da polinização de quatro espécies de Eugenia L. (Myrtaceae). Acta Bot Bras 21:235-247

Silva CI, Augusto SC, Sofia SH, Moscheta IS (2007) Diversidade de abelhas em Tecoma stans ( L.) Kunth ( Bignoniaceae ): Importância na polinização e produção de frutos. Neotrop Entomol 36:331-341 
Siqueira KMM, Kill LHP, Martins CF, Silva LT (2011) Ecologia da polinização de Psidium guajava L . ( Myrtaceae): riqueza, frequência e horário de atividades de visitantes florais em um sistema agrícola. Magistra 24:150-157

Siqueira KMM, Martins CF, Kill LHP, Silva LT (2011) Estudo comparativo da polinização em variedades de aceroleiras (Malpighia emarginata DC, Malpighiaceae). Rev Caatinga 24:18-25

Smith-Pardo A, Gonzalez VH (2007) Diversidad de abejas ( hymenoptera : apoidea ) en estados sucesionales del bosque húmedo tropical. Acta Biol Colomb 12:43-55

Sofia SH, Santos AM, Silva CRM (2004) Euglossine bees (Hymenoptera, Apidae) in a remnant of atlantic forest in Paraná State, Brazil. Iheringia Sér Zool 94:217-222

Sofia SH, Suzuki KM (2004) Comunidades de machos de abelhas Euglossina ( Hymenoptera: Apidae ) em fragmentos florestais no sul do Brasil. Neotrop Entomol 33:693-702

Storck-Tonon D, Silva MV, Morato EF (2011) Checklist of orchid bees (Hymenoptera: Apidae) of "Lago do Silencio" Area, Boca do Acre, Amazonas, Brazil. Check List 7:648-651

Storck-Tonon D, Morato EF, Oliveira ML (2009) Fauna de Euglossina (Hymenoptera: Apidae) da Amazônia Sul-Ocidental, Acre, Brasil. Acta Amaz 39:693-706

Mouga DMD, Neto PN (2012) A high grassland bee community in southern Brazil: survey and annotated checklist (Insecta: Apidae). J Kans Entomol Soc 85:295308

Tonhasca Jr A, Albuquerque GS, Blackmer JL (2003) Dispersal of euglossine bees between fragments of the Brazilian Atlantic Forest. J Trop Ecol 19: 99-102 
Torres C, Dambolena JS, Zunino MP, Galetto L (2012) Nectar characteristics and pollinators for three native, co-occurring insect-pollinated Passiflora (Passifloraceae ) from central Argentina. The International Journal of Plant Reproductive Biology 4:121-126

Trovão DB, Souza BC, Carvalho ED, Oliveira PB (2009) Espécies vegetais da caatinga associadas às comunidades de abelhas ( Hymenoptera: Apoidea: Apiformis ). Rev Caatinga 22:136-143

Varassin IG, Sazima M (2012) Spatial heterogeneity and the distribution of bromeliad pollinators in the Atlantic Forest. Acta Oecol 43, 104-112.

Viana BF, Kleinert AMP, Neves EL (2002) Comunidade de Euglossini (Hymenoptera, Apidae) das dunas Litorâneas do Abaeté, Salvador, Bahia, Brasil. Rev Bras Entomol 46:539-545

Viana BF, Santos IA (2002) Bee diversity of the coastal sand dunes of Brazil. Pollinating Bees - The Conservation Link Between Agriculture and Nature Ministry of Environment, Brasília.

Viana BF, Silva FO, Kleinert AMP (2001) Diversidade e sazonalidade de abelhas Solitárias ( Hymenoptera : Apoidea ) em dunas litorâneas no nordeste do Brasil. Neotrop Entomol 30:245-251

Vilhena AMGF, Augusto SC (2006) Polinizadores da aceroleira Malpighia emarginata DC ( Malpighiaceae ) em área de cerrado no triângulo mineiro. Biosci J 23:1423

Zotarelli HGS, Evans DM, Bego LR, Sofia SH (2014) A comparison of social bee-plant networks between two urban areas. Neotrop Entomol 43:399-408 


\section{Online Resource 2}

Table A1. Scores the area under the receiver operating characteristic (ROC) curve (AUC) and true skill statistic (TSS) to ensemble forecasting, random forest (RF), flexible discriminant analysis (FDA), Generalized linear models (GLM), classification tree analysis (CTA) and Maximum Entropy (MAXENT) and cutoff AUC and TSS to each specie. Ex. analis (Exomalopsis analis), B. morio (Bombus morio), Eu. nigrita (Eulaema nigrita), C. tarsata (Centris tarsata) and A. callichroa (Augochloropsis callichroa).

\begin{tabular}{|c|c|c|c|c|c|c|c|c|}
\hline & & Ensemble & $\mathrm{RF}$ & FDA & GLM & CTA & Maxent & Cutoff \\
\hline \multirow[t]{2}{*}{ Ex. analis } & AUC & 0.990 & 0.962 & 0.931 & 0.922 & 0.860 & 0.813 & 573.0 \\
\hline & TSS & 0.900 & 0.832 & 0.795 & 0.788 & 0.686 & 0.626 & 572.0 \\
\hline \multirow[t]{2}{*}{ B. morio } & AUC & 0.995 & 0.986 & 0.968 & 0.963 & 0.937 & 0.896 & 462.5 \\
\hline & TSS & 0.937 & 0.924 & 0.863 & 0.880 & 0.855 & 0.793 & 460.0 \\
\hline \multirow[t]{2}{*}{ Eu. nigrita } & AUC & 0.995 & 0.959 & 0.883 & 0.845 & 0.875 & 0.842 & 491.5 \\
\hline & TSS & 0.932 & 0.807 & 0.674 & 0.598 & 0.681 & 0.633 & 492.0 \\
\hline \multirow[t]{2}{*}{ C. tarsata } & AUC & 0.992 & 0.965 & 0.922 & 0.886 & 0.891 & 0.847 & 476.5 \\
\hline & TSS & 0.938 & 0.841 & 0.761 & 0.716 & 0.743 & 0.685 & 476.5 \\
\hline \multirow{2}{*}{ A. callichroa } & AUC & 0.998 & 0.858 & 0.827 & 0.788 & 0.681 & 0.740 & 496.0 \\
\hline & TSS & 0.957 & 0.709 & 0.669 & 0.618 & 0.368 & 0.479 & 494.0 \\
\hline
\end{tabular}




\section{Considerações finais}

As ameaças antrópicas estudadas em diferentes escalas: local, inseticidas, regional, vegetação nativa e fragmentação, e biogeográfica, mudanças climáticas, afetam os polinizadores do tomateiro, porém esse impacto é diferenciado para cada grupo/espécie. Os resultados do presente estudo sugerem que o desmatamento, os inseticidas e as mudanças climáticas podem afetar negativamente a abundância, a saúde e a distribuição espacial futura de abelhas nativas polinizadoras associadas aos cultivos de tomate. Esta constatação tem sérias implicações para a conservação, para o serviço de polinização e, consequentemente para a produtividade desse cultivo e compõe um quadro mundial desfavorável que somado a outras ameaças impostas a esses grupos compromete a manutenção da biodiversidade em paisagens dominadas por atividades humanas.

O contexto da paisagem influenciou a abundância dos cinco grupos de polinizadores do tomateiro e não houve um padrão geral para todos os grupos. Essa diferença na resposta entre as espécies pode ser um importante mecanismo promovendo a estabilidade desse serviço ecossistêmico (Winfree \& Kremen 2009).

A proporção de vegetação nativa e a fragmentação da paisagem tiveram efeito positivo sobre a abundância para maioria dos grupos de polinizadores. Esses resultados indicam que a manutenção e conservação da vegetação nativa é de grande importância para espécies de abelhas nativas associadas aos cultivos de tomate, pois até mesmo pequenos fragmentos podem ser responsáveis por aumentar a diversidade de habitats e fornecer recursos cruciais para manutenção das espécies (Tscharntke et al. 2002b; Rueda et al. 2013). No entanto, fato preocupante é que a perda de habitat e a fragmentação ainda são duas das principais ameaças aos polinizadores nos países em desenvolvimento na atualidade (Aizen et al. 2008). Por último, não houve relação entre 
abundância dos grupos e a distância do fragmento. São necessários estudos adicionais que permitam um delineamento no qual hajam distâncias maiores entre os cultivos e a vegetação nativa e que abordem essa relação no nível de espécie para evitar que os atributos de várias espécies possam influenciar a resposta.

De acordo com o nosso conhecimento esse é o primeiro estudo a analisar os efeitos genotóxicos de inseticidas em abelhas. Nas concentrações subletais utilizadas o inseticida deltametrina, do grupo dos piretróides é genotóxico ao DNA de células da hemolinfa de abelhas Melipona quadrifasciata enquanto o inseticida o imidacloprid, do grupo dos neonicotinóides, não apresentou genotoxicidade. Estudos adicionais são necessários para uma melhor compreensão da genotoxicidade de ambos inseticidas. Danos do DNA causado pelo inseticida deltametrina poderia impactar negativamente a sobrevivência e o sucesso reprodutivo da espécie $M$. quadifasciata. Uma das medidas práticas que deveriam ser adotadas para redução do uso de inseticidas é adoção de métodos agrícolas mais sustentáveis (Goulson et al. 2015).

A mudança climática prevista para o ano de 2100 pode causar redução na distribuição geográfica das cinco espécies associadas a culturas de tomate no Brasil. Na atualidade, há um alto grau de concordância entre área plantada de tomate e a distribuição geográfica das cinco espécies polinizadoras do tomateiro, porém para o ano de 2100 grande parte dessa concordância deixará de existir. Ambos os resultados sugerem que essas cinco espécies de abelhas e o serviço de polinização tomateiro podem ser ameaçados no futuro pelas mudanças climáticas. Algumas medidas poderiam mitigar a ameaça das mudanças climáticas sobre as abelhas, como por exemplo, a migração assistida, embora controversa e a busca de refúgios nos biomas originais (Kerr et al. 2015), mas o mais importante seria o comprometimento de todos para a redução das emissões de gases de efeito estufa. 
As abelhas estão sujeitas a inúmeras ameaças da atividade antrópica e esses estressores não agem de forma isolada. Perda de habitat, fragmentação, exposição crônica a coquetéis de agroquímicos e novos parasitas são alguns dos exemplos agindo em conjunto. Além disso, as alterações climáticas são susceptíveis de agravar estes problemas no futuro. Portanto, nesse meio tempo, tomar medidas para reduzir o estresse sobre as abelhas parece prudente e urgente (Goulson et al. 2015). 


\section{Referências bibliográficas}

Aizen, M. A., Garibaldi, L. A., Cunningham, S. A., Klein, A. M. Long-term global trends in crop yield and production reveal no current pollination shortage but increasing pollinator dependency (2008) Current Biology, 18: 1572 -1575.

Goulson, D., Nicholls, E., Botías, C., Rotheray, E.L. (2015) Bee declines driven by combined stress from parasites, pesticides, and lack of flowers. Science. <http://www.sciencemag.org/cgi/doi/10.1126/science.1255957> Acesso em: 5 de abril de 2015.

Kerr J.T., Pindar, A., Galpern, P., Packer, L., Potts, S.G., Roberts, S.M., Rasmont, P., Schweiger, O., Colla, S.R., Richardson, L.L., Wagner, D.L., Gall, L.F., Sikes, D.S., Pantoja, A. (2015) Climate change impacts on bumblebees converge across continents. Science, 349: 177-180.

Rueda, M., Hawkins, B.A., Morales-Castilha, I., Vidanes, R.M., Ferrero, M., Rodríguez, M. Á. (2013) Does fragmentation increase extinction thresholds? A European-wide test with seven forest birds. Global Ecology and Biogeography, 22, 1282-1292.

Tscharntke, T., Steffan-Dewenter, I., Kruess, A., Thies, C. (2002b) Contribution of small habitat fragments to conservation of insect communities of grasslandcropland landscapes. Ecological Applications, 12, 354-363.

Winfree, R., Kremen, C. (2009) Are ecosystem services stabilized by differences among species? A test using crop pollination. Proceedings of the Royal Society B, 276, $229-237$. 


\section{Anexo 1 - Material suplementar do capítulo I}

Tabela S1. Estimativas dos coeficientes dos modelos médios para a relação entre a abundância de abelhas do grupo Buzzers nas flores dos cultivos de tomate e a proporção de vegetação nativa (Prop) e o tamanho relativo do maior fragmento (rLPS) em 10 cultivos de tomate convencional estaqueado em campo aberto no ano de 2010 e 14 cultivos de tomate no ano de 2011. IC-inferior, intervalo de confiança limite inferior e IC-superior, intervalo de confiança limite superior, Obsv. tempo, tempo de observação.

\begin{tabular}{cccccc}
\hline & Buzzers & Estimativa & IC-inferior & IC-superior & $\mathbf{Z}$ \\
\hline & Intercept & 3,177 & 1,527 & 4,827 & 20,691 \\
& Prop 2Km & 7,980 & 6,330 & 9,630 & 9,482 \\
$\overline{\bar{\nu}}$ & rLPS 2Km & $-2,540$ & $-3,326$ & $-1,748$ & $-6,303$ \\
& & & & & \\
\hline & Intercept & 2,417 & 1,994 & 2,945 & 10,174 \\
$\overline{\bar{\nabla}}$ & Obsv. time & 1,525 & 0,668 & 2,382 & 3,489 \\
\hline
\end{tabular}


Tabela S2. Estimativas dos coeficientes dos modelos médios para a relação entre a abundância de abelhas do grupo Exomalopis nas flores dos cultivos de tomate e a proporção de vegetação nativa (Prop) e o tamanho relativo do maior fragmento (rLPS) em 10 cultivos de tomate convencional estaqueado em campo aberto no ano de 2010 e 14 cultivos de tomate no ano de 2011. IC-inferior, intervalo de confiança limite inferior e IC-superior, intervalo de confiança limite superior, Obsv. tempo, tempo de observação.

\begin{tabular}{|c|c|c|c|c|c|}
\hline & Exomalopsis & Estimativa & IC-inferior & IC-superior & $\mathbf{Z}$ \\
\hline \multirow{4}{*}{ 을 } & Intercept & 2,665 & 2,310 & 3,020 & 14,727 \\
\hline & Prop $2 \mathrm{Km}$ & 10,675 & 8,641 & 12,709 & 10,288 \\
\hline & rLPS $2 \mathrm{Km}$ & - 3,898 & - 4,880 & - 2,916 & - 7,782 \\
\hline & Intercept & 2,415 & 1,862 & 2,968 & 8,573 \\
\hline & Prop 1Km & 2,267 & 1,275 & 3,258 & 4,480 \\
\hline$\overline{\bar{\ominus}}$ & Obsv. time & 0,006 & 0,002 & 0,010 & 3,201 \\
\hline
\end{tabular}


Tabela S3. Estimativas dos coeficientes dos modelos médios para a relação entre a abundância de abelhas do grupo Halictidae nas flores dos cultivos de tomate e a proporção de vegetação nativa (Prop) e o tamanho relativo do maior fragmento (rLPS) em 10 cultivos de tomate convencional estaqueado em campo aberto no ano de 2010 e 14 cultivos de tomate no ano de 2011. IC-inferior, intervalo de confiança limite inferior e IC-superior, intervalo de confiança limite superior, Obsv. tempo, tempo de observação.

\begin{tabular}{|c|c|c|c|c|c|}
\hline & Halictidae & Estimativa & IC-inferior & IC-superior & $\mathbf{Z}$ \\
\hline \multirow{5}{*}{$\stackrel{\ominus}{\bar{\nu}}$} & Intercept & 5,418 & 3,845 & 6,990 & 5,727 \\
\hline & Prop $3 \mathrm{Km}$ & $-17,245$ & $-26,313$ & - 8,177 & 3,260 \\
\hline & rLPS 3Km & 1,306 & $-1,277$ & 3,890 & 0,928 \\
\hline & Intercept & 1,600 & 0,098 & 3,102 & 1,894 \\
\hline & Prop 3Km & 1,087 & $-3,120$ & 5,294 & 0,480 \\
\hline$\overline{\bar{\theta}}$ & rLPS $3 \mathrm{Km}$ & $-4,446$ & $-6,075$ & - 2,816 & 4,746 \\
\hline
\end{tabular}


Tabela S4. Estimativas dos coeficientes dos modelos médios para a relação entre a abundância de abelhas do grupo Centris nas flores dos cultivos de tomate e a proporção de vegetação nativa (Prop) e o tamanho relativo do maior fragmento (rLPS) em 10 cultivos de tomate convencional estaqueado em campo aberto no ano de 2010 e 14 cultivos de tomate no ano de 2011. IC-inferior, intervalo de confiança limite inferior e IC-superior, intervalo de confiança limite superior, Obsv. tempo, tempo de observação.

\begin{tabular}{|c|c|c|c|c|c|}
\hline & Centris & Estimativa & IC-inferior & IC-superior & $\mathbf{Z}$ \\
\hline \multirow{3}{*}{$\stackrel{\vec{\theta}}{\stackrel{\theta}{\ominus}}$} & Intercept & $-1,122$ & $-2,407$ & 0,163 & $-1,711$ \\
\hline & Prop 3km & 12,796 & 7,952 & 17,641 & 5,177 \\
\hline & Intercept & $-2,528$ & $-4,708$ & $-0,348$ & $-2,273$ \\
\hline \multirow{2}{*}{$\overline{\bar{\delta}}$} & Prop 2km & 6,265 & 2,336 & 10,195 & 3,125 \\
\hline & Obsv. time & 0,020 & 0,007 & 0,032 & 3,006 \\
\hline
\end{tabular}


Tabela S5. Estimativas dos coeficientes dos modelos médios para a relação entre a abundância de abelhas do grupo Bombus/Eulaema nas flores dos cultivos de tomate e a proporção de vegetação nativa (Prop) e o tamanho relativo do maior fragmento (rLPS) em 10 cultivos de tomate convencional estaqueado em campo aberto no ano de 2010 e 14 cultivos de tomate no ano de 2011. IC-inferior, intervalo de confiança limite inferior e IC-superior, intervalo de confiança limite superior, Obsv. tempo, tempo de observação.

\begin{tabular}{|c|c|c|c|c|c|}
\hline & Bombus/Eulaema & Estimativa & IC-inferior & IC-superior & $\mathbf{Z}$ \\
\hline \multirow{3}{*}{ 을 } & Intercept & $-1,827$ & $-4,773$ & 1,119 & 1,216 \\
\hline & Prop $3 \mathrm{Km}$ & 8,427 & $-5,738$ & 22,592 & 1,110 \\
\hline & Prop 1,5 Km & 2,172 & $-4,255$ & 8,599 & 0,640 \\
\hline \multirow{3}{*}{$\overline{\bar{\nu}}$} & Intercept & $-3,733$ & $-7,215$ & $-0,250$ & - 2,101 \\
\hline & rLPS 3Km & - 7,044 & $-12,878$ & $-1,210$ & $-2,367$ \\
\hline & Obsv. time & 0,046 & 0,021 & 0,071 & 3,665 \\
\hline
\end{tabular}


Tabela S6. Variáveis preditoras e variáveis respostas para os 24 cultivos de tomateiro convencional estaqueado em campo aberto em 2010 e 2011. (Prop.) corresponde à proporção de vegetação nativa, (rLPS) tamanho relativo do maior fragmento e (A. Buz.) abundância de todos polinizadores juntos (buzzers), (A. Exo), abundância do grupo exomalopsis, (A.Centris) abundância do grupo centris, (A. Halic) abundância do grupo halictidae e (A.B/Eu) abundância do grupo bombus/Eulaema.

\begin{tabular}{|c|c|c|c|c|c|c|c|c|c|c|c|c|c|c|c|c|c|}
\hline Cultivos & Ano & $\begin{array}{l}\text { Distância } \\
\text { (m) }\end{array}$ & $\begin{array}{c}\text { Prop. } \\
0,75 \mathrm{Km}\end{array}$ & $\begin{array}{l}\text { Prop. } \\
1 \mathrm{Km}\end{array}$ & $\begin{array}{l}\text { Prop. } \\
1,5 \mathrm{Km}\end{array}$ & $\begin{array}{l}\text { Prop. } \\
2 \mathrm{Km}\end{array}$ & $\begin{array}{l}\text { Prop. } \\
3 \mathrm{Km}\end{array}$ & $\begin{array}{l}\text { RLPS } \\
0,75 \mathrm{Km}\end{array}$ & $\begin{array}{l}\text { RLP\& } \\
1 \mathrm{Km}\end{array}$ & $\begin{array}{l}\text { RLPs } \\
1,5 \mathrm{Km}\end{array}$ & $\begin{array}{l}\text { RLPs } \\
2 \mathrm{Km}\end{array}$ & $\begin{array}{l}\text { RLP\& } \\
3 \mathrm{Km}\end{array}$ & A.Buz & A.ExQ & A.Centris & A.Halic & A.B/Eu \\
\hline wilgoia.10 & 10 & 346 & 0,370 & 0,400 & 0,382 & 0,309 & 0,273 & 0,619 & 0,577 & 0,452 & 0,384 & 0,344 & 132 & 102 & 14 & 9 & 7 \\
\hline ruth. 10 & 10 & 96 & 0,208 & 0,224 & 0,178 & 0,194 & 0,181 & 0,518 & 0,417 & 0,233 & 0,162 & 0,112 & 29 & 27 & 0 & 2 & 0 \\
\hline apar.10 & 10 & 346 & 0,160 & 0,180 & 0,167 & 0,221 & 0,264 & 0,483 & 0,322 & 0,294 & 0,177 & 0,241 & 154 & 130 & 16 & 3 & 5 \\
\hline armand.10 & 10 & 12 & 0,133 & 0,128 & 0,145 & 0,166 & 0,176 & 0,519 & 0,456 & 0,341 & 0,255 & 0,265 & 63 & 34 & 0 & 29 & 0 \\
\hline cigan.10 & 10 & 10 & 0,548 & 0,410 & 0,342 & 0,338 & 0,324 & 0,998 & 0,976 & 0,696 & 0,497 & 0,393 & 70 & 54 & 13 & 1 & 2 \\
\hline dirce. 10 & 10 & 156 & 0,218 & 0,200 & 0,194 & 0,175 & 0,234 & 0,832 & 0,723 & 0,470 & 0,330 & 0,343 & 63 & 49 & 2 & 7 & 5 \\
\hline edvarg.10 & 10 & 54 & 0,264 & 0,255 & 0,217 & 0,219 & 0,252 & 0,944 & 0,881 & 0,611 & 0,493 & 0,638 & 57 & 40 & 12 & 4 & 1 \\
\hline 1carlos.10 & 10 & 145 & 0,277 & 0,266 & 0,210 & 0,202 & 0,224 & 0,422 & 0,505 & 0,465 & 0,491 & 0,290 & 21 & 4 & 12 & 3 & 2 \\
\hline rivael.10 & 10 & 338 & 0,172 & 0,187 & 0,191 & 0,194 & 0,209 & 0,306 & 0,221 & 0,217 & 0,202 & 0,176 & 29 & 23 & 5 & 1 & 0 \\
\hline valner.10 & 10 & 186 & 0,119 & 0,150 & 0,179 & 0,175 & 0,220 & 0,468 & 0,326 & 0,240 & 0,232 & 0,150 & 38 & 24 & 4 & 10 & 0 \\
\hline elt.11 & 11 & 94 & 0,221 & 0,170 & 0,120 & 0,150 & 0,200 & 0,507 & 0,459 & 0,408 & 0,267 & 0,328 & 26 & 22 & 0 & 4 & 0 \\
\hline jai.11 & 11 & 335 & 0,134 & 0,160 & 0,149 & 0,195 & 0,286 & 0,654 & 0,758 & 0,561 & 0,282 & 0,261 & 94 & 47 & 6 & 33 & 8 \\
\hline jur.11 & 11 & 258 & 0,042 & 0,032 & 0,105 & 0,119 & 0,199 & 1,000 & 0,901 & 0,340 & 0,283 & 0,466 & 37 & 28 & 2 & 7 & 0 \\
\hline dd. 11 & 11 & 122 & 0,055 & 0,057 & 0,078 & 0,137 & 0,237 & 0,815 & 0,440 & 0,152 & 0,222 & 0,232 & 35 & 28 & 1 & 5 & 1 \\
\hline apa.11 & 11 & 143 & 0,221 & 0,244 & 0,354 & 0,358 & 0,323 & 0,395 & 0,366 & 0,384 & 0,437 & 0,489 & 26 & 13 & 8 & 4 & 1 \\
\hline luc.11 & 11 & 70 & 0,269 & 0,234 & 0,219 & 0,206 & 0,206 & 0,723 & 0,698 & 0,646 & 0,555 & 0,316 & 57 & 41 & 5 & 9 & 2 \\
\hline mar.11 & 11 & 152 & 0,387 & 0,295 & 0,220 & 0,225 & 0,301 & 0,875 & 0,896 & 0,697 & 0,451 & 0,312 & 40 & 37 & 0 & 3 & 0 \\
\hline osv.11 & 11 & 67 & 0,125 & 0,132 & 0,202 & 0,274 & 0,249 & 0,972 & 0,718 & 0,557 & 0,411 & 0,462 & 38 & 21 & 15 & 2 & 0 \\
\hline rig.11 & 11 & 358 & 0,184 & 0,159 & 0,123 & 0,136 & 0,223 & 0,558 & 0,523 & 0,572 & 0,568 & 0,259 & 32 & 25 & 4 & 3 & 0 \\
\hline $\operatorname{rin} .11$ & 11 & 539 & 0,147 & 0,180 & 0,213 & 0,209 & 0,217 & 0,505 & 0,469 & 0,228 & 0,217 & 0,356 & 53 & 42 & 9 & 0 & 2 \\
\hline $\operatorname{van} .11$ & 11 & 15 & 0,110 & 0,113 & 0,105 & 0,103 & 0,132 & 0,879 & 0,551 & 0,382 & 0,398 & 0,559 & 53 & 48 & 0 & 5 & 0 \\
\hline vil.11 & 11 & 284 & 0,256 & 0,317 & 0,344 & 0,333 & 0,298 & 0,467 & 0,848 & 0,571 & 0,361 & 0,377 & 55 & 49 & 1 & 5 & 0 \\
\hline rud.11 & 11 & 200 & 0,151 & 0,162 & 0,197 & 0,196 & 0,227 & 0,468 & 0,435 & 0,269 & 0,231 & 0,127 & 79 & 46 & 0 & 31 & 2 \\
\hline tum. 11 & 11 & 295 & 0,296 & 0,343 & 0,320 & 0,326 & 0,293 & 0,577 & 0,455 & 0,467 & 0,678 & 0,739 & 73 & 68 & 0 & 5 & 0 \\
\hline
\end{tabular}

